FEDERAL RESERVE BANK OF SAN FRANCISCO

WORKING PAPER SERIES

\title{
Financial Crises and the Composition of Cross-Border Lending
}

\author{
Eugenio Cerutti \\ International Monetary Fund \\ Galina B. Hale \\ Federal Reserve Bank of San Francisco \\ Camelia Minoiu \\ International Monetary Fund
}

August 2014

Working Paper 2014-20

http://www.frbsf.org/economic-research/publications/working-papers/wp2014-20.pdf

The views in this paper are solely the responsibility of the authors and should not be interpreted as reflecting the views of the Federal Reserve Bank of San Francisco or the Board of Governors of the Federal Reserve System. 


\title{
Financial Crises and the Composition of Cross-Border Lending ${ }^{ \pm}$
}

\author{
Eugenio Cerutti \\ International Monetary Fund \\ Galina Hale \\ Federal Reserve Bank of San Francisco \\ Camelia Minoiu \\ International Monetary Fund
}

August 10, 2014

We examine the composition and drivers of cross-border bank lending between 1995 and 2012, distinguishing between syndicated and non-syndicated loans. We show that on-balance sheet syndicated loan exposures, which account for almost one third of total cross-border loan exposures, increased during the global financial crisis due to large drawdowns on credit lines extended before the crisis. Our empirical analysis of the drivers of cross-border loan exposures in a large bilateral dataset leads to three main results. First, banks with lower levels of capital favor syndicated over other kinds of cross-border loans. Second, borrower country characteristics such as level of development, economic size, and capital account openness, are less important in driving syndicated than non-syndicated loan activity, suggesting a diversification motive for syndication. Third, information asymmetries between lender and borrower countries became more binding for both types of cross-border lending activity during the recent crisis.

Key words: cross-border banking, syndicated loans, global financial crisis, BIS international banking statistics, Dealogic Loan Analytics

JEL classification codes: F30, F65, G15

\footnotetext{
${ }^{ \pm}$Author e-mail addresses: ECerutti@imf.org; galina.b.hale@sf.frb.org; CMinoiu@imf.org. We are grateful to Stijn Claessens, Ricardo Correa, Tümer Kapan, Mahvash Qureshi, Aparna Sehgal, Elod Takats, our discussant Viktoria Hnatkovska, and participants at the $16^{\text {th }}$ Annual Syndicated Loans Conference (London, March 2014) and the JIMFUSC conference "Financial adjustment in the aftermath of the global crisis 2008-09: A new global order?" (Los Angeles, April 2014) for useful comments. We thank Kristin Forbes and Frank Warnock for generously sharing their data. Peter Jones, Keith Miao, and Javier Quintero provided outstanding research assistance. The views expressed in this paper are those of the authors and do not necessarily reflect those of Federal Reserve System, the IMF, their Executive Boards, or their policies. Any errors are our own.
} 


\section{Introduction}

The past two decades have witnessed a remarkable increase in cross-border bank lending activity. Between 1995 and 2012, total cross-border loan claims have almost tripled to reach 20 trillion U.S. dollars. Some of this activity is conducted in the form of syndicated loans, in which a group of financial institutions (a syndicate) supplies funds to an individual borrower (a firm or a sovereign) under a single loan agreement. Loan syndications help lenders overcome balance sheet constraints and reduce the concentration of risks by limiting exposures to individual borrowers. Smaller lenders benefit from the informational advantages of larger banks to diversify risks across countries and borrowers to which they would otherwise not have access. How important the syndicated loan market is relative to total cross-border bank lending operations is still an open question. In this paper, we describe the composition of cross-border bank lending during 1995-2012, focusing on syndicated loans, and examine its evolution and drivers.

We begin by documenting stylized facts about the share of syndicated lending in crossborder bank loan exposures. We find that syndicated loan exposures ('SLEs') represent between 20 percent of total loan claims early in the sample to over 30 percent in later years. On average the share of SLEs in total loan claims is higher vis-à-vis advanced economy (AE) borrowers (30 percent) compared to emerging market economy (EME) borrowers (18 percent). Non-syndicated loan exposures ('non-SLEs'), which include bilateral (single-lender loans) and intragroup lending (loans among entities of the same banking group) account for the remainder. ${ }^{1}$

Next, we analyze the effects of the global financial crisis (2008-2012) on the composition of cross-border loan exposures. We find that during the crisis there was an increase in SLEs (stocks) despite a collapse in syndicated loan origination (flows). ${ }^{2}$ This was driven by an increase in drawdowns on existing syndicated loan commitments (credit lines). Our estimates suggest that credit line usage rates increased from approximately 25 percent before the global financial crisis to 52 percent by 2012. Composition effects related to the longer maturity of the syndicated loans extended in the pre-crisis boom may also have played a role.

We also identify key drivers of loan syndication activity compared to other types of cross-border lending, and provide evidence for several motives behind syndication. For the

\footnotetext{
${ }^{1}$ Due to data limitations, we are unable to further break down non-SLEs into their single-lender and intragroup activity components. See Section 4.2 for details.

${ }^{2}$ Total deal volume fell in 2009 by more than 50 percent from its 2007 peak of 4.5 trillion U.S. dollars, on account of the 2007-2008 liquidity shocks and strained balance sheets of financial intermediaries (Brunnermeier , 2009) and a fall in credit demand (Kahle and Stulz, 2013).
} 
empirical analysis, we construct a bilateral (country-pair) panel of 26 lender countries and 76 borrower countries between 1995 and 2012. We find that greater informational asymmetries, measured by the degree of economic integration and geographical distance between lender and borrower countries, are associated with lower total cross-border loan activity. Banks with lower levels of capital in lender countries favor syndicated loans over other kinds of cross-border loans. Borrower country characteristics such as level of development, economic size, and capital account openness, play a lesser role for SLEs compared to non-SLEs, suggesting a diversification motive for syndications. During the global financial crisis, both SLEs and nonSLEs were higher for country pairs with lower information asymmetries.

We use two main sources to construct our data. Information on syndicated loans is available at the transaction level from Dealogic Loan Analytics. The data are highly granular as we are able to see, for each loan deal, the identity of all the contracting parties and the terms of the deal. Availability of this data has spurred a large literature in international finance. ${ }^{3}$ To this we add data on cross-border bank activities from the Bank for International Settlements (BIS) international banking statistics (IBS). The BIS statistics report cross-border assets and liabilities of creditor banking systems vis-à-vis borrower countries. ${ }^{4}$

The two data sources enable us to compare, for the first time in the literature, syndicated and total cross-border bank loan exposures, and thus gauge the importance of international syndicated loans. This comparison, however, is not trivial. The BIS data provide banking sector exposures (stocks) at a given point in time, while syndicated loan data reflect loan origination (flows). In addition, syndicated loan data comprise not only disbursed loans, but also loan commitments (credit lines) that may not be fully drawn over the life of the loan. Using data on the volume and maturity of syndicated loan deals, we estimate the stock of outstanding crossborder syndicated loans at the lender-borrower country-pair level using the same aggregation

\footnotetext{
${ }^{3}$ To give a few examples, syndicated loan data has been used to study the international transmission of financial shocks (de Haas and van Horen, 2013) and portfolio rebalancing (Giannetti and Laeven, 2012), emerging market access to foreign capital (Hale, 2007), and the evolution of the global banking network (Hale, Kapan, and Minoiu, 2014; Hale, 2012). An important corporate finance literature on lender incentives in the process of syndication uses the same data or subsets of the data from other providers (see, e.g., Gopalan, Nanda and Yerramilli, 2011; Berndt and Gupta, 2009; Sufi, 2007).

${ }^{4}$ The BIS IBS have been used to study international bank flows through banking centers, financial networks, globalization, and contagion. Recent contributions include Cerutti and Claessens (2013), Cerutti (2103), KalemliOzcan, Papaioannou and Peydro (2013), Minoiu and Reyes (2013), Cetorelli and Goldberg (2011), and Degryse, Elahi, and Penas (2010).
} 
criteria as the BIS IBS. We also make several adjustments to obtain estimates of cross-border SLEs that are comparable to the BIS loan claims. ${ }^{5}$

Our study expands on two branches of the international banking literature. First, we add to studies on the globalization of banking (see Goldberg, 2009 for a review) and the determinants of cross-border bank-intermediated capital flows. Blank and Buch (2010) document the drivers of cross-border bank assets and liabilities, focusing on their short-run response to macroeconomic fluctuations. They show that bank asset and liability positions are closely linked to bilateral trade, interest rate differentials, and market size. Kleimeier, Sander and Heuchemer (2013) argue that geographical and cultural proximity between European countries are key determinants of cross-border bank loans and deposits despite banking market integration. We extend this work first by estimating the distinct components of international bank loan portfolios, and second by assessing the performance of a gravity-like model in explaining their variation. Our results also speak to the behavior of banking flows during crises (Hoggarth, Mahadeva, and Martin, 2010; Kaminsky, 2008) as we allow the impact of different factors to change during the global financial crisis.

Second, we add to existing research of banks' decision to syndicate rather than extend bilateral loans. Godlewski and Weill (2007) studies loan facilities to EME borrowers and emphasizes financial development and legal institutions in the borrower's country among the relevant factors. Banks are less likely to extend syndicated loans to borrowers from countries with a larger stock market and better institutions (creditor rights and rule of law), suggesting a diversification motive for syndication. Based on a sample of syndicated loan deals to US borrowers, Simons (1993) argues that loan syndications are mainly driven by lender balance sheet strength. Banks with lower capital and liquidity are likely to prefer adding smaller loans to their balance sheets and hence to syndicate. Our empirical results, which focus on cross-border lending activity only, supports these arguments, as we find that lender balance sheets are more important for SLEs while borrower risk profiles are more relevant for non-SLEs.

The remainder of the paper is structured as follows. In Section 2 we describe the main features of the loan syndication market and provide a short historical account. In Section 3 we discuss the data sources and transformations that enable us to estimate the components of crossborder bank loan exposures. We discuss stylized facts on the composition of banks' international

\footnotetext{
${ }^{5}$ Throughout the paper we use the terms "claims" and "exposures" interchangeably.
} 
loan exposures in Section 4. In Section 5 we examine its drivers based on a number of empirical hypotheses. Section 6 concludes. Detailed information on data sources, transformations, and additional results are included in the Appendix.

\section{Features and history of the syndicated loan market ${ }^{6}$}

Loan syndications became popular in the 1970 s as a source of private funding to emerging market sovereigns in Africa, Asia, and Latin America. The lenders were Western banks with excess liquidity positions from recycled petrodollars (Tucker, Madura, and Chiang, 1991). In 1982 this market was severely disrupted when EME borrowers, especially in Latin America, failed to meet payment obligations, and US banks took large losses on their syndicated credits. As a backstop, the outstanding loans were restructured into bonds guaranteed by the US government ("Brady bonds") in 1989. This restructuring led the market to recover, with crossborder loan origination to private and public institutions expanding rapidly in the following two decades, alongside the international bond market. Global syndicated loan volume increased 160 percent between 1995 and 2012 to reach 3.5 trillion U.S. dollars, positioning the market as a competitor for the bond market, which originated 6.5 trillion U.S. dollars worth of new issuances in 2012.

Syndicated loans are extended to a single borrower by a group of financial institutions called a "syndicate." Syndicates comprise banks and non-bank financial institutions and can range in size from two to dozens of participants. Syndicate participants are organized according to seniority structure: the so-called bookrunners are the most senior lenders. They interact with the borrower, negotiate the loan, collect participating bids from other lenders, administer payments, and receive the highest fees. Less senior participating institutions, such as mandated arrangers, interact less with the borrower and contribute smaller amounts towards the loan. The least senior syndicate members act as arms-length lenders. During 1995-2012 the average syndicate had 6.2 participants, including 2.7 lead banks (bookrunners or mandated arrangers). In terms of geographical composition of syndicates, on average during 1995-2012 syndicates had 46 percent foreign banks and 54 percent domestic banks, and close to 60 percent of all syndicated loan deals had at least one foreign participant.

\footnotetext{
${ }^{6}$ See Appendix Figure A1 (Panels A-L) for charts on syndicate size, borrower types, market concentration, currency composition, loan deal terms for AE vs. EME borrowers, and for domestic vs. cross-border loans.
} 
Most loan deals are denominated in U.S. dollars (with the euro and the yen also accounting for a significant share) and are priced over LIBOR. Syndicated loans tend to be large and longer-term than other loans. The average loan extended at the peak of the market in 2007 amounted to almost half a billion U.S. dollars but loan size decreased during the global financial crisis, especially to AE borrowers. Average loan deal maturity during 1995-2012 was 4.7 years. This means that syndicated loans have longer maturity than bilateral cross-border loans, for which we estimate an average maturity of 3.1 years, as well as relative to all loans on the balance sheet of banks in AEs, for which we estimate an average maturity of 3 years. ${ }^{7}$

Close to 90 percent of total deal volume accrues to AE borrowers. The average deal to EME borrowers is typically half the size of that to AE borrowers. Loan spreads were hovering around 150-200 basis points over LIBOR before the global financial crisis, and were similar for AE and EME borrowers. ${ }^{8}$ Spreads doubled at the height of the crisis, when loan origination collapsed. Although EME borrowers have historically obtained longer-term loans than AE borrowers, this gap appears to have increased during the crisis. The borrowers in this market tend to be large and creditworthy firms: ${ }^{9}$ roughly 75 percent of loans go to non-financial firms, 15 percent to financial firms, and 10 percent to sovereigns and public sector entities. The borrower base for the syndicated loan market is becoming less concentrated. The total market share of the top 100 borrowers has declined since the mid-1990s from about 45 percent to about 25 percent in 2012 - the same figure as in the international bond market. However, the syndicated loan market has historically been more concentrated than the bond market.

Loan syndication is an important source of underwriting revenue for global banks, which compete for market share and a leading spot in Dealogic's League Tables. In 2012, the top five global underwriters, by market share, were JP Morgan, Bank of America Merrill Lynch, Citigroup, Mizuho Financial Group, and Wells Fargo \& Co. Most of the loan origination activity

\footnotetext{
${ }^{7}$ The figures 3.1 and 3 years are upper bound estimates computed as follows. For the first one we use BIS consolidated claims of reporting banks on an immediate borrower basis (Table 9A), with the caveat that these claims also include some foreign currency-denominated local claims (that is, non-cross border loans). Weighted average maturity is computed conservatively by assuming maturity of 1 year for the "up to 1 year interval", 2 years for "1-2 years," and 7 years for " $>2$ years". For the second estimate, we obtain loan maturity information for 425 banks in 2012 from SNL Financial database. For these banks, 30 percent of loans have maturity of $<1$ year, 36 percent have maturity $1-5$ years, and the remaining 34 percent have maturity $>5$ years. We also compute the average maturity by assuming the upper bound for each interval, and 7 years for " $>5$ years".

${ }^{8}$ We caution that pricing information is missing for many loans in our sample, possibly in a non-random way.

${ }^{9}$ In a sample of syndicated loans from Loan Pricing Corporation, between 1986 and 2001 two thirds of nonfinancial US firms borrowing from syndicates had investment grade rating, while for other large loans less than half had investment grade rating (Hale and Santos, 2008).
} 
is carried out by banks headquartered in AEs. There are significant reputational costs associated with the loan syndication business: although defaults in the syndicated loan market are rare, they can impact the lead bank's reputation and future ability to place a syndicated loan (Gopalan, Nanda and Yerramilli, 2011; Pichler and Wilhelm, 2001). As a result, lead banks tend to hold greater portions of the loans on their books as a signal of loan screening and monitoring (Sufi, 2007; Lee and Mullineaux, 2004).

Although syndicated loans are typically held to maturity, they can be sold in an active secondary market. ${ }^{10}$ The presence of this market means that banks could treat syndicated loans as an originate-to-distribute type transaction, much like loan securitization. In theory this can reduce lenders' incentives to do due diligence (Keys, Mukherjee, Seru, and Vig, 2010).

Empirical evidence, however, suggests that this may not be the case because lead banks still face reputational costs even if they fully remove the loans from their balance sheets. Bushman and Wittenberg-Moerman (2009) show that borrowers of syndicated loans that are traded on the secondary market do not perform worse than those of non-traded loans. Benmelech, Dlugosz, and Ivashina (2012) examine loan holdings for collateralized loan obligations and show that, for each originating bank, securitized syndicated loans do not underperform unsecuritized ones. The authors argue that this is unique to syndicated loans, likely because their structure works towards aligning lender incentives.

\section{Data}

Our main data sources are Dealogic Loan Analytics for syndicated loans and the BIS IBS for cross-border bank claims. From Loan Analytics we downloaded more than 150,000 syndicated loan deals extended between 1990 and 2012 to estimate syndicated loan exposures at the country-pair level during 1995-2012. ${ }^{11}$ For each loan deal we have detailed information on lender and borrower identity as well as contract characteristics such as loan type (credit line, term loan), size, maturity, pricing, and currency. For purposes of our analysis, we follow the

\footnotetext{
${ }^{10}$ Empirical studies show that the secondary market for syndicated loans is efficient in terms of incorporating borrower information into prices, e.g., default and bankruptcy information (Altman, Gande, and Saunders, 2010) and earnings (Allen, Guo, and Weintrop, 2008).

${ }^{11}$ We limit our period of analysis to 1995-2012 for two reasons. First, Loan Analytics data on syndicated loan origination before 1990 is of lower quality than post-1990 data, therefore we have more confidence in post-1995 estimated SLEs. Second, this ensures maximum availability of data on key country characteristics.
} 
literature and split loan volumes equally across syndicate participants to obtain lender-specific loan amounts and exposures (see Giannetti and Laeven, 2012; Hale, 2012). ${ }^{12}$

The second dataset, the BIS IBS, provides a comprehensive picture of total cross-border bank claims, and is organized in two datasets - locational and consolidated banking statistics. These data capture exposures (i.e., loans, securities, and other claims) of the most important lender countries vis-à-vis their borrowers worldwide. It is important to note that BIS banking statistics comprise only the claims of the banking system in lender countries. Consolidated data track banks' gross claims and other exposures (with intragroup positions being netted out and consolidated across offices worldwide), while locational data are residence-based, that is, they track the exposures of banks located in a particular country. ${ }^{13}$

Our goal is to estimate cross-border syndicated loan claims that are comparable to BIS cross-border loan claims, allowing us to gauge the size of the loan syndication market. We start by constructing cross-border syndicated loan exposures (stocks) for each lender vis-à-vis each borrower using loan volumes and maturity. We then aggregate these exposures at the countrypair level aggregating on both a consolidated and locational basis using information on the location of the lender and borrower, and the nationality of the lender's parent.

Most of our analysis focuses on the locational aggregation because the BIS locational data has longer time series coverage than consolidated data. Nevertheless, we also make use of the consolidated data to estimate the on-balance sheet share of syndicated credit lines, which is a crucial step in making SLEs comparable to BIS loan claims.

\section{The syndicated loan market and total cross-border bank lending activity}

\subsection{Constructing syndicated loan exposures}

We begin with a preliminary comparison of total cross-border loan claims on a locational basis from the BIS with our estimated SLEs. Figure 1 depicts this comparison over the period from 1995 to 2012, with both variables expressed in trillions of constant U.S. dollars (2005 prices). Between 1995 and 2007, total cross-border loan claims rose three-fold, reflecting an increase in financial integration. Estimated SLEs increased over the same period by a

\footnotetext{
12 This imputation is needed because lender-specific loan shares are missing for a large proportion of loans. In the Appendix we show that the approach of splitting loan deal amounts equally across lenders produces estimates of loan exposures at the country pair-level (our unit of analysis) that are similar to those of other approaches proposed in the literature (see Appendix Table A1).

${ }^{13}$ See Appendix for further information on both data sources.
} 
comparable amount. However, there was a significant decrease in total bank loan claims during the global financial crisis (by about 5 trillion U.S. dollars from their 2007 peak to 2012) while SLEs did not experience the same decrease over the period.

More strikingly, Figure 1 shows that our estimated SLEs exceed total cross-border loan claims from the BIS about half of the time. There are two explanations for this. First, some participants in the loan syndication market are non-bank institutional investors (asset managers, hedge funds, private equity funds, etc.), while the BIS IBS only capture banks' positions. Second, syndicated loan deals often involve credit lines that are not fully drawn over the life of the loan. For these reasons, the SLEs computed thus far overstate the size of the market.

To make the two series comparable, we perform two adjustments, both of which we believe deliver plausible estimates of SLEs. ${ }^{14}$ First, syndicated loans that are reported as either credit lines or "Term Loan A"-type term loans are extended almost exclusively by banks (Culp, 2013; Benmelech, Duglosz, and Ivashina, 2012; Nandy and Shao, 2010; Nini, 2008). While the syndicates of other loan deals (mainly term loans not classified as Term Loan A) may also include banks, it is difficult to identify them precisely and separate banks from non-bank institutional lenders for each deal. For this reason, we adjust the SLEs to only refer to credit lines and term loans of type A.

The second adjustment is necessary because the credit lines reported in Loan Analytics include both on-balance sheet, drawn amounts, and off-balance sheet, undrawn amounts. To obtain an estimate of the drawn amounts that are relevant in the comparison with the BIS loan claims (which only capture on-balance sheet positions), we need information on credit line utilization. To obtain credit line usage rates, for each borrower and year, we compare syndicated credit line exposures aggregated on a consolidated basis with undrawn credit lines from the BIS consolidated banking statistics (available for a limited number of lender countries from 2005 onwards). ${ }^{15}$

Our estimated credit line usage rates rose from approximately 25 percent before the global financial crisis to 40 percent by 2009 and further to 57 percent by 2011 at the height of the European sovereign debt crisis. These estimates are consistent with evidence for the US that credit line utilization varies over the business cycle. Mian and Santos (2012) report that credit

\footnotetext{
${ }^{14}$ See Appendix for a detailed description of these adjustments.

${ }^{15}$ See Appendix for more details and Table A2 for credit line usage rate estimates.
} 
line utilization rose by about 17 percentage points for US firms when credit conditions were tight. Ivashina and Scharfstein (2010) and Berrospide and Meisenzahl (2013) document significant credit line drawdowns by US firms as the subprime crisis gathered pace. Correa, Sapriza, and Zlate (2013) document a usage ratio of about one third for US branches of foreign banks in 2010. While these estimates are not directly comparable to ours due to differences in data and methodology, we are reassured that the trend we uncovered is consistent with that documented in the literature. We use the credit line utilization rates to adjust the credit line component of SLEs downwards and hence to obtain "adjusted SLEs" that are comparable to the BIS loan claims.

\subsection{The composition of cross-border bank loan exposures}

Figure 2 breaks out the BIS total cross-border loan claims into the adjusted SLEs and non-SLEs (a residual obtained as the difference between BIS loan claims and adjusted SLEs). Panel A includes all borrowers, while panels B and C are for AE and EME borrowers, respectively. From 1995 to 2012 the share of syndicated lending in total loan claims fluctuated between 17 and 41 percent in the full sample, between 19 and 47 for AE borrowers and between 10 and 27 percent for EME borrowers. Over time, the relative importance of the syndicated loan market has grown. ${ }^{16}$

Although loan volumes to EMEs are significantly lower than those to AEs, these figures suggest that syndicated loans are a significant source of funding for both AE and EME borrowers. ${ }^{17}$ They are also consistent with other estimates. Ivashina and Scharfstein (2010) report that SLEs represent about 20 percent of total commercial and industrial loan exposures of US banks and about 30 percent for large US and foreign banks. According to a survey of 50 US

\footnotetext{
${ }^{16}$ SLEs and BIS total loan claims co-move significantly, which suggests that SLEs can be a useful proxy for crossborder bank lending activity when BIS data are unavailable. When we regress BIS total loan claims on (unadjusted) SLEs, we find that about 50 percent of the variation in total exposures is explained by variation in SLEs. Countrypair and year fixed effects explain an additional 25 percent of the total variation (Appendix Table B1). These findings, about stocks, complement an earlier result that about 50 percent of the variance in international bank lending to EME borrowers is explained by changes in syndicated loan volumes (Gadanecz and von Kleist, 2002). This degree of co-movement suggests that developments in the syndicated loan market can provide useful information about global bank lending activity before BIS statistics are released.

${ }^{17}$ Nevertheless, there is significant heterogeneity in the share of SLEs in total loan positions across lender and borrower countries (Appendix Figure B1). The median share during 1995-2012 varies from almost zero for the Cayman Islands, Cyprus, and Panama to over 20 percent for Australia, Japan, and South Africa. SLEs are zero for offshore financial centers as loan origination in these jurisdictions is mainly carried out by non-bank institutional lenders (Aramonte, Lee, and Stebunovs, 2014).
} 
banks representative of the banking sector size distribution, Huang (2010) finds that SLEs account for less than 5 percent of commercial and industrial loan claims for one fourth of banks, 5-20 percent for half of the banks, and 20-50 percent for one fifth of the surveyed banks.

Figure 2 also reveals a steep increase in BIS total loan claims in the run-up to the global financial crisis for both $\mathrm{AE}$ and EME borrowers, followed by a reduction in exposures to $\mathrm{AE}$ borrowers during the crisis that is consistent with the deleveraging process described in Cerutti and Claessens (2013) and Milesi-Ferretti and Tille (2011). Unlike total exposures, however, we notice that SLEs increased during the crisis. There are two explanations for this increase. First, as mentioned, drawdowns on existing syndicated credit lines increased markedly during the crisis. Second, maturities for most syndicated loans lengthened during the credit boom prior to the crisis. Average maturity of loan deals increased from 3.8 years in 2002 to 5.3 years in 2007, leading fewer loans to mature during the crisis. These two factors combined induced stickiness in the dynamics of SLEs.

What do we know about the residual component of cross-border loan claims, which is generated through other kinds of cross-border loans? Non-SLEs refer to bilateral and intragroup loans. The BIS IBS do not distinguish between these components. However, we can use the BIS locational statistics to obtain a rough idea of the composition of non-SLEs. In particular, we look at the breakdown of banks' international positions into assets vis-à-vis related offices (which are indicative of the contribution of intragroup lending), and vis-à-vis unrelated banks, non-banks, and official monetary authorities. We find that intragroup loans account for 28.8 percent of total claims.

Using our adjusted SLEs, the estimated contribution of intragroup lending to banks' international positions, and the residual (i.e., the contribution of bilateral loans), we are now able to fully describe the composition of cross-border bank lending from 1995 to 2012. As a rough estimate for the whole period, these components contribute to total cross-border loan exposures about one third each. ${ }^{18}$

\footnotetext{
$\overline{{ }^{18} \text { See Appendix Figures A3 and A4. }}$
} 


\section{Drivers of cross-border bank lending activity}

\subsection{Hypotheses and variables}

In this section we investigate the factors driving the composition of cross-border bank loan claims, focusing on a comparison of the determinants of SLEs and non-SLEs. Our empirical analysis draws on studies of the determinants of cross-border capital flows (Bruno and Shin, 2013; Lane and Milesi-Ferretti, 2008) and of banks' decisions to syndicate or extend bilateral loans (Altunbas, Gadanecz, and Kara, 2006). The baseline set of covariates for SLEs and nonSLEs includes country-pair, lender, and borrower characteristics.

Our starting point is based on observations regarding the main push-pull and gravity-type drivers of cross border capital flows. For each set of potential covariates, we discuss the differences and similarities between syndicated loans and other types of cross-border loans. In developing the hypotheses and interpreting the results, we are mindful that non-SLEs reflect two types of loans - bilateral and intragroup loans - and hence determinants of each type of loan may operate in opposite directions to influence the non-SLE aggregate.

Observation 1: Greater information asymmetries reduce cross-border bank lending. To test this idea, we include several variables that capture economic, cultural, and geographic distance between the lender and the borrower country as measures of the information and monitoring costs involved in cross-border lending activity between the two countries. Our proxies include bilateral trade, geographical distance, and an indicator for the countries speaking a common language. Giannetti and Yafeh (2011) highlight the importance of cultural differences between lead banks and borrowers for the terms of syndicated loans and show that these differences do not vanish even after repeated interactions between the contracting parties. We expect that information asymmetries will play a role for both syndicated and non-syndicated loan exposures. However, it is possible that they are reduced through the process of syndication because most syndicates include domestic banks, which are more likely to have local knowledge of the borrower. ${ }^{19} \mathrm{We}$ also expect that information asymmetries play a greater role during times of financial stress.

Observation 2: Balance sheet constraints and size of lender banks influence their ability to intermediate cross-border credit. The ability of a banking system to intermediate credit across

\footnotetext{
${ }^{19}$ In 2012,86 percent of loan deals were extended by syndicates with at least one domestic bank.
} 
borders is closely linked to its level of development and sophistication, the strength of bank balance sheets, and regulation. Balance sheets of financial intermediaries are a key channel of shock transmission (Cetorelli and Goldberg, 2012; Van Rijckeghem and Weder, 2003). But which constraints will matter more for SLEs compared to non-SLEs? Syndicated loans help banks reduce exposures to individual borrowers, which enable them to manage concentration risk and satisfy regulatory limits on concentration. When capital and liquidity constraints are more binding, banks may prefer to syndicate rather than to add large bilateral loans to their balance sheets (Simons, 1993). By contrast, banks that are larger and more profitable may be better able to invest the necessary resources to acquire borrower knowledge and extend loans bilaterally (Altunbas, Gadanecz, and Kara, 2006). To capture these ideas, we include in our analysis lender country characteristics such as per capita income level and size of the banking system as proxies for the lender country's capacity to extend cross-border credit and banking system sophistication. Our main proxy for lender capital will be the bank total regulatory capitalto-asset ratio. In line with studies of the role of capital in sustaining lending to the real economy after the failure of Lehman Brothers (Kapan and Minoiu, 2014), we expect capital constraints to become more binding during the global financial crisis. Banking system regulation is a slowlymoving variable and is controlled for with lender country fixed effects. To capture bank balance sheet strength and profitability we also look at the impact of net interest margins, returns on assets, and non-performing assets on loan exposures. The measure of lender size is total banking system assets.

Observation 3: Borrower country risk characteristics affect the willingness of lenders to extend cross-border credit and the ability of borrowers to access it. Another reason why banks choose to syndicate loans is portfolio diversification. Syndication offers the possibility to benefit from the lead bank's knowledge of the borrower and expertise lending to a given market; by contrast, bilateral lending requires costly market research and relationship-building. Borrower country risk characteristics that are generally relevant in a bank's decision to extend cross-border loans should reflect external and domestic vulnerabilities, and may include solvency, liquidity, and financial openness. Since syndicated loans allow banks to diversify risks by lending to a wide range of borrowers, including riskier ones, we expect the borrower risk profile to be less relevant for SLEs compared to non-SLEs. We consider borrower country variables such as per capita income (as a proxy for both the demand for cross-border loans as well as the ability of the 
domestic financial sector to meet that demand), size of the domestic banking system (as a proxy for its capacity to meet local demand and co-syndicate with global banks), institutional quality (as a measure of contract enforcement), and capital account openness (as a broad measure of barriers to foreign bank entry and foreign competition, and government influence on financial services).

\subsection{Regression specification}

We investigate how differences between syndicated loan deals and other types of crossborder loans translate into drivers of SLEs and non-SLEs using our bilateral dataset for the 1995-2012 period. We estimate regressions which take the form:

$$
\log \left(S L E_{i j t}\right)=\alpha_{i}+\delta_{j}+\lambda_{t}+X_{i t} \beta_{1}+Y_{j t} \beta_{2}+Z_{i j t} \gamma+\varepsilon_{i j t}
$$

where $\alpha_{i}$ and $\delta_{j}$ are lender and borrower country fixed effects, $\lambda_{t}$ are year fixed effects, $X_{i t}$ is a set of lender country time-varying characteristics, $Y_{j t}$ is a set of borrower country time-varying characteristics, $Z_{i j t}$ comprises time-varying country pair-level variables, and $\varepsilon_{i j t}$ are well-behaved errors. We use the same specifications for non-SLEs:

$$
\log \left(\text { non }-S L E_{i j t}\right)=\alpha^{\prime}{ }_{i}+\delta^{\prime}{ }_{j}+\lambda^{\prime}{ }_{t}+X_{i t} \beta^{\prime}{ }_{1}+Y_{j t} \beta^{\prime}{ }_{2}+Z_{i j t} \gamma^{\prime}+\xi_{i j t}
$$

Lender and borrower countries are indexed by $i$ and $j$, respectively. Our regression sample includes 26 lender countries and 76 borrower countries (listed in Table 1). We perform the analysis on country-pairs with non-zero cross-border syndicated loan activity (unbalanced panel). Descriptions and sources for the regression variables are included in Table 2 and descriptive statistics for selected variables are show in Table $3 .{ }^{20}$ All coefficients are estimated using Ordinary Least Squares (OLS) and standard errors are clustered on country pair.

In addition to the country characteristics discussed in the previous section, we include the following control variables in all regressions:

- An indicator for presence of foreign affiliates of lender country $i$ in borrower country $j$. This variable captures the mechanical effect that presence of foreign affiliates has on the intragroup lending component of non-SLEs. It may also capture the fact that global banks sometimes co-syndicate loans with their affiliates in the borrower's country.

\footnotetext{
${ }^{20}$ Appendix Table B2 reports unconditional correlations between the dependent variables and selected regressors.
} 
- Total other lending $(\log )$ and total other borrowing $(\log )$ : For lender country $i$, "total other lending" is the sum of loan exposures to borrowers other than $j$ at time $t$. Similarly, for borrower country $j$, "total other borrowing" is the sum of loan liabilities vis-à-vis lender countries other than $i$ at time $t$. These variables control for heterogeneity in borrower and lender dynamics.

In subsequent specifications, we add interaction terms between a global financial crisis indicator (for the years from 2008 to 2012) and selected covariates. We add country fixed effects in all baseline specifications, and alternatively country-pair fixed effects in the robustness section to control for time-invariant gravity-type characteristics. Unless otherwise specified, all regressions include year fixed effects which capture the impact of global variables such as uncertainty and risk aversion. In the robustness section and Appendix we also present specifications that control for a wider range of pair- and country-level characteristics than considered in the baseline and assess the sensitivity of our results to alternative methodological choices.

\subsection{Empirical results}

\subsubsection{Baseline}

Table 4 presents our baseline results for the two dependent variables: SLEs (columns 1-3) and non-SLEs (columns 4-6). Our aim in these specifications is to explore the correlates of different types of cross-border loan exposures as opposed to identifying their fundamental determinants. For this reason, we caution that our results should not be interpreted causally.

The estimates in columns 1-3 of Table 4 show that higher volume of trade between lender and borrower countries, lower geographical distance between the capitals of the two countries, and sharing a common language, all indicating lower information asymmetries, are associated with higher SLEs. These results extend to non-SLEs, although the coefficient on "common language" remains statistically significant only for exposures to EME borrowers. These results speak to the importance of informational and monitoring costs in international lending transactions, and are consistent with the findings from gravity-type models for capital flows (Herrmann and Mihaljek, 2013; Portes and Rey, 2005). The positive and statistically significant coefficient on bilateral trade also suggests that economic and financial integration go hand in hand: a 10 percent increase in bilateral trade is associated with a 2.4-2.6 percent increase in 
cross-border loan exposures (columns 1,7). Similarly, a 10 percent decrease in geographical distance brings about an increase in loan exposures by between 4 and 8 percent (columns 1, 7).

In terms of lender country characteristics, there are both similarities and differences in the drivers of SLEs and non-SLEs. The income level and the size of the lender's banking system do not influence cross-border loan exposures of either kind. By contrast, capital of lender banks seems to play an important role for SLEs: higher levels of capital (measured with the regulatory capital-to-assets ratio) are associated with lower SLEs. A 1 percentage point increase in the capital-to-assets ratio — about half a standard deviation in our sample—reduces SLEs by 4.9 percent (column 1). This finding confirms our hypothesis that lower capital levels act as an incentive for banks to syndicate large loans rather than to add them wholly to their balance sheets, and complements Simons (1993)'s result that less well capitalized lead banks tend to retain smaller shares of syndicated loans. In theory the impact of capital on lending is ambiguous, as better capitalized banks can take on larger credit risks, but weakly capitalized banks may also cause credit creation as they have little capital at stake in the case of losses (Peydro, 2010). In our data there is no association between the degree of capitalization and nonSLEs (columns 4-6). For each dependent variable, we do not find any significant evidence that lender characteristics play a different role for loan exposures vis-à-vis AE and EME borrowers. Moving to borrower country characteristics, we notice several important distinctions in the link between borrower risk profile and syndicated vs. non-syndicated lending. Among the borrower characteristics considered - per capita income, banking sector size, institutional quality, and capital account openness - the only feature that appears to systematically favor syndicated lending is institutional quality (columns 1-3). (However, we will see that this result is not very robust in subsequent specifications.) Looking at a sample of syndicated and singlelender loans to EME borrowers, Godlewski and Weill (2008) argue that borrower country institutional quality is a crucial part of the decision to syndicate, and that heterogeneity in the expansion of syndicated loan across EMEs may be explained by cross-country differences in institutions rather than financial development and banking regulations. Institutional quality may matter more for syndicated than for bilateral loans because global banks tend to co-lend with local banks so as to benefit from their knowledge of the borrower and market, and institutional quality may capture the availability and the quality of those lenders (Gadanecz, 2004). 
By contrast, non-SLEs are higher vis-à-vis borrowers from higher income countries, countries with larger banking systems, and countries with more open capital accounts- that is, less risky borrowers (columns 4-6). The diversification motive that favors syndicated over bilateral loans implies that banks extending bilateral loans may be less willing to serve risky borrowers because they are taking on full loans on their balance sheets, hence bearing the full credit risk. This idea is consistent with our finding that most of the borrower country risk and economic structure variables are relevant for non-SLEs. The result that non-SLEs are larger visà-vis higher-income $\mathrm{AE}$ borrowers (column 5) could capture the lower risk associated with these borrowers and the fact that internal capital market transactions could be larger with affiliates in higher income countries. The finding that non-SLEs are larger vis-à-vis EME borrowers with higher capital account openness (column 6) speaks to the idea that financial freedom and low barriers to foreign bank activity are a greater concern for EME borrowers.

From Table 4 we can also see that our control variables generally yield statistically significant coefficients. The presence of foreign affiliates of the lender country in the borrower country raises loan exposures of both kinds. The variables measuring total exposure of each lender and borrower generally yield positive and statistically significant coefficients.

Overall, our baseline results provide support for gravity-type models of cross-border bank assets, with $\mathrm{R}^{2}$ in excess of 70 percent. These are comparable to the coefficients of determination documented in Portes and Rey (2005) for a parsimonious model of cross-border equity flows and indicate that our baseline covariates capture most of the variation in crosscountry bank loan allocations.

\subsubsection{Interactions with the global financial crisis}

In Table 5 we explore the interaction between selected drivers of cross-border bank loan claims and the global financial crisis. We estimate models with interactions between an indicator for the 2008-2012 period and, respectively, bilateral trade, geographical distance, lender bank capital ratio, borrower capital account openness, and borrower institutional quality. The effect of the global financial crisis is subsumed in the year fixed effects.

Looking at the interactions with measures of informational costs, we see that country pairs with higher bilateral trade and lower geographical distance had higher cross-border loan exposures during the crisis. Higher borrower capital account openness and better institutions are 
also associated with higher loan exposures during the crisis (although the coefficient for institutional quality is statistically significant only for non-SLEs). There is no evidence that lender capital mattered more during the crisis. When all interaction terms are added at the same time (columns 6,12), we notice that only the effect of bilateral trade survives. The point estimates suggest that, during the crisis, country pairs with total trade flows higher by 10 percent experienced increases in cross-border loan exposures that were higher by 2.3-2.6 percent. This result suggests that countries with stronger economic ties and hence lower information asymmetries also experienced higher financial integration during the recent crisis. ${ }^{21}$

This finding is consistent with the idea that when the need for loan screening and monitoring rises, as it does during financial crises when borrowers become riskier, economic proximity becomes more relevant for cross-border bank lending activity. It also relates to studies of the deleveraging process that took place after the collapse of Lehman Brothers. De Haas and van Horen (2013) show that deleveraging was heterogeneous, with banks reducing loan origination more vis-à-vis borrowers from countries in which they had less lending experience, fewer domestic co-lenders, and less local presence.

The coefficient estimates on other variables are largely unaffected by the inclusion of the interaction terms. The only exception is the size of the borrower country banking system, which is now positively correlated with both types of cross-border loan exposures (but the coefficient magnitudes are lower for SLEs). ${ }^{22}$

\subsection{Robustness analysis}

We subject the analysis to several robustness checks, as follows: first, we assess the sensitivity of our results to the inclusion of country-pair fixed effects (instead of country fixed effects). Then, we examine richer specifications that include a lagged dependent variable to account for persistence of loan exposures. Finally, we evaluate the impact of additional lender

\footnotetext{
${ }^{21}$ These results are driven by the subsample of exposures vis-à-vis AE borrowers (Appendix Tables B3 and B4).

${ }^{22}$ In results not reported, we also experimented with specifications in which we included country-specific financial crises, both for lenders and the borrowers, in levels and interacted with pair and country characteristics. We used three different proxies for financial crises: systemic banking crises dated by Laeven and Valencia (2013); growth recessions for the years when growth collapsed to less than one standard deviation below the long-run trend; and capital flow retrenchments in lender countries as well as capital flow sudden stops for borrower countries (Forbes and Warnock, 2012). We did not find any consistent results for systemic banking crises, but there was some evidence that both SLEs and non-SLEs decline during borrower growth recessions and sudden stops, and that these declines are higher relative to higher-risk borrower countries. Further, we did not find any evidence of additional effects of joint financial crises at the country-pair level.
} 
and borrower country characteristics on cross-border loan exposures; and the stability of our results in the pre-global financial crisis period.

\subsubsection{Alternative estimation approaches}

The first robustness check concerns our choice to include country-level fixed effects in the baseline specifications, by which we implicitly assume that relevant country-pair timeinvariant heterogeneity is unrelated to the included regressors. Here we relax this assumption by including country-pair fixed effects in the baseline model to control for trust, historical and cultural ties, and informational frictions between the lender and borrower country that are difficult to measure. The results (Table 6) indicate that our baseline results are largely robust to including country-pair fixed effects. The only exceptions are the coefficients on the foreign affiliate dummy, which is highly persistent at the country-pair level (and thus largely absorbed by the pair effects) and those on the borrower institutional quality variable, which are positive across specifications, but lose statistical significance.

A related robustness check regards the choice of baseline specification. So far we have not accounted for the fact that cross-border loan exposures may be highly persistent, which would invite adding a lagged dependent variable to the covariate set. Including this variable is more demanding of the data as it requires that the regressors explain only the variation in loan exposures that is not accounted for by past loan exposures. We examine the impact of this variable in specifications estimated as follows: (i) OLS with country fixed effects, (ii) OLS with country-pair fixed effects (both for comparison purposes), and (iii) OLS with bias correction for short panels. The OLS estimates in (i) and (ii) are reliable under the assumption that the panel, which spans 16 years, is deep enough for the OLS bias on all the regressors to be small (Kiviet, 1995). This assumption is relaxed in (iii), where estimates are obtained with the bias-corrected least squares dummy variable dynamic panel data estimator with initial Anderson-Hsiao coefficient values and bootstrapped standard errors (Bruno, 2005). ${ }^{23}$ The disadvantage of this approach is that we cannot estimate coefficients on time-invariant bilateral variables (such as common language and geographical distance). The results (shown in Appendix Table B5) reveal that the autoregressive coefficient is around 0.5 , which does not indicate a high level of

\footnotetext{
${ }^{23}$ We also estimated the baseline specifications with the system GMM estimator, but found the results to be unreliable. Due to the large set of instruments (country and/or country-pair fixed effects) the estimator produces unstable coefficients with large standard errors.
} 
persistence. Furthermore, estimates for the effects of other regressors are largely robust across the three estimation methods: higher lender capital reduces SLEs, while higher borrower income, a larger banking system, and higher capital account openness increase non-SLEs. The coefficient on borrower institutional quality loses statistical significance when we add country-pair fixed effects or use the bias-corrected estimator.

\subsubsection{Additional country characteristics}

A possible worry about our baseline model is that it is too parsimonious, and omitted lender and borrower characteristics may play a role in driving cross-border bank loan exposures in a way that is not fully captured by our included covariates. The omission of these variables may not only lead to some erroneous conclusions, but could also conceal interesting heterogeneity in the results. To address this concern, we augment the baseline specifications with several lender and borrower country characteristics (largely inspired by the work of Altunbas, Gadanecz, and Kara, 2006). For lenders, we focus on balance sheet strength and profitability; for borrowers, on their risk profile.

First, we run regressions with a rich set of lender variables to capture balance sheet characteristics that may favor syndicated over bilateral lending. These include (i) net interest margins and return on assets; (ii) liquid assets-to-deposits ratio; (iii) loan loss reserves and net charge-offs (as proxies for banks' quality of the existing loan portfolio and their ability to absorb future losses). Net interest margins and return on assets may be inversely related to syndicated lending as more profitable banks are better able to invest resources to extend loans bilaterally; conversely, these variables may be positively related to syndicated lending if they reflect a riskier business model. The liquidity ratio should be negatively related to syndicated lending since banks with lower levels of liquidity may be hesitant to add large bilateral loans to their balance sheets and prefer adding smaller, syndicated portions instead (Simons, 1993). We expect banks with worse-quality loan portfolios and/or lower loan loss reserves to be less willing to add large credit risks to their balance sheets and thus to prefer syndications as well.

The estimation results for specifications in which we add all these variables one at a time and simultaneously (Table 7) suggest that the only relevant variable is loan portfolio quality (measured by net charge offs in percent of average gross loans), which is positively associated with SLEs and unrelated to non-SLEs (columns 6,12). We notice, however, that the inclusion of 
this variable removes the statistical significance of the coefficient on capital (columns 5-6), which remains nonetheless negative. This suggests that the capital result for syndicated loans may be driven by the association between low capital and high write-offs on non-performing loans; or that the lower sample size reduces the precision of the estimate on capital.

Second, we examine the sensitivity of our main results to the inclusion of additional variables that reflect the borrower country's level of financial development and macroeconomic volatility. We expect these variables to be positively correlated with both types of cross-border loan exposures. According to the diversification motive for syndications, we may find borrower economic strength to be less relevant for SLEs compared to non-SLEs. The additional variables include exchange rate volatility (as a measure of external vulnerability but also of flexibility of the exchange rate regime), stock market capitalization (a measure of financial deepening), stock market return volatility, \% of internationally rated banks (a proxy for the ability of the domestic banking system to meet credit demand and co-syndicate with international banks), and S\&P sovereign credit rating (a comprehensive measure of borrower solvency that reflects income level, growth, inflation, external debt, and default history).

The results (Table 8) suggest that our main messages survive the inclusion of these additional variables. Interestingly, the only factor that matters for both SLEs and non-SLEs is stock market return volatility; as expected, higher borrower stock market volatility is associated with lower cross-border loan exposures. However, we prefer not to include this variable in the baseline because the sample size drops significantly due to its limited availability. When all variables are included at the same time (columns 6,12 ), we notice that the share of internationally rated banks in the borrower's banking system is positively linked to non-SLEs. This effect may be explained by the fact that internal transfers within banking groups require the presence of subsidiaries in the host country, which are more likely to be internationally rated. Alternatively, the share of internationally rated banks may reflect the level of financial sector sophistication in the borrower country.

\subsubsection{Robustness to alternative time period}

The last robustness check concerns the fact that our results may be driven by the global financial crisis period. To test whether this is the case, we restrict the sample to the 1995-2007 period. The results (shown in Appendix Table B6) reveal that our main findings hold up in this 
alternate sample: high levels of bank capital in lender countries are negatively associated with SLEs (columns 1-3), and borrower country income, banking system size, and capital account openness are positively related to non-SLEs (columns 4-6). Better institutional quality in the borrower country increases syndicated loans to EME borrowers only (column 3).

\section{Conclusions}

In this paper we described the composition of cross-border bank lending during 1995 2012 , focusing on the contribution of the international loan syndication market. Our goal has been to document the importance of this market as a source of funding to borrowers worldwide, and to examine the drivers of syndicated and non-syndicated loan exposures over the business cycle. To construct our sample, we brought together information on cross-border bank lending activities from two widely-used datasets: the BIS international banking statistics, which provide aggregate data on cross-border bank loan claims, and Dealogic Loan Analytics, which reports transaction-level data on syndicated loan deals. We performed multiple adjustments to the data to obtain estimates of cross-border syndicated loan exposures, at the country-pair-year level, that are comparable to the BIS cross-border loan claims.

We found that the share of cross-border syndicated lending ranges from 20 percent to more than 30 percent of total cross-border loan claims in the full sample. This finding is consistent with previous studies which report that approximately one third of loan exposures on the typical US bank balance sheet are syndicated credits. Ours is the first set of estimates that refer to a large international sample of lender and borrower countries. We find that cross-border syndicated loan exposures increased during the global financial crisis due to large credit line drawdowns. Syndicated loan exposures co-move significantly with total cross-border loan claims, but there is a great deal of heterogeneity in the share of syndicated loan exposures across countries and over time. This suggests that caution should be exercised in treating syndicated loan data as representative of total cross-border bank lending activities.

Our empirical analysis of the drivers of cross-border loan exposures revealed that banks with lower levels of capital favor loan syndications over other types of cross-border loans (including bilateral loans). Borrower country characteristics such as level of development, economic size, and capital account openness, play a lesser role in driving syndicated loan exposures, suggesting a diversification motive for syndication. During the global financial crisis, 
higher information asymmetries between the lender and borrower countries reduced cross-border loan exposures. Our results are largely robust to a battery of specification checks, such as the inclusion of country-pair fixed effects, accounting for persistence with a lagged dependent variable, and expanding the covariate set with additional lender and borrower country characteristics.

As empirical research on global banking grows, so does the use of the two datasets analyzed here. In this paper we shed light not only on the relationship between these two data sources, but also on the composition of banks' international loan portfolios, its cross-sectional characteristics and time dynamics. Evaluating the role of the syndicated loan market is just the first step towards gaining a more complete picture of international bank lending. Future research should aim at further deconstructing aggregate bank exposures, for instance by estimating the share of intragroup lending, to which we only alluded in this paper. 


\section{References}

Altman, E. I., Gande, A. and A. Saunders, 2010, "Bank debt versus bond debt: Evidence from secondary market prices," Journal of Money, Credit and Banking, Vol. 42(4), pp. 755-767.

Allen, L., Guo, H. and J. Weintrop, 2008, “The Information Content of Quarterly Earnings in Syndicated Bank Loan Prices," Asia-Pacific Journal of Accounting \& Economics, Vol. 15(2), pp. 91-121.

Altunbas, Y., Ganadecz, B. and A. Kara, 2006, Syndicated loans: A hybrid of relationship lending and publicly traded debt, Palgrave Macmillan Studies in Banking and Financial Institutions, Palgrave Macmillan.

Aramonte, S., Lee, S. J., and V. Stebunovs, 2014, "Low interest rates and risk allocation in the US syndicated loan market," Paper presented at the Workshop on Systemically Important Financial Institutions: A Research Agenda, Beijing, February 24-25, 2014.

Benmelech, E., J. Dlugosz and V. Ivashina (2012), "Securitization without adverse selection: The case of CLOs," Journal of Financial Economics, Vol. 106(1), pp. 91-113.

Berrospide, J. M. and R. R. Meisenzahl, 2013, "The real effects of credit line drawdowns," Board of Governors of the Federal Reserve System, mimeo.

Blank, S. and C. M. Buch, 2010, "International bank portfolios: short and long-run responses to macroeconomic conditions," Review of International Economics, Vol. 18(2), pp. 289-306.

Brunnermeier, M., 2009, "Deciphering the liquidity and credit crunch 2007-2008," Journal of Economic Perspectives, Vol. 23, pp. 77-100.

Bruno, G. S. F., 2005, “Approximating the bias of the LSDV estimator for dynamic unbalanced panel data models," Economics Letters, Vol. 87, pp. 361-366.

Bruno, V., and H. Shin, 2013, “Capital flows, cross-border banking, and global liquidity,” NBER Working Paper No. 19038.

Bushman, R. M. and R. Wittenberg-Moerman, 2009, "Does secondary loan market trading destroy lenders' incentives?” Chicago Booth Research Paper No. 09-45.

Cerutti, E., 2013, “Banks' foreign credit exposures and borrowers' rollover risks: Measurement, evolution and determinants," IMF Working Paper No. 13/9. 
Cerutti, E. and S. Claessens, 2013, "The great cross-border bank deleveraging: Supply side characteristics," Paper presented at the PSE/BdF/NYFed/CEPR Workshop on the Economics of Cross-Border Banking, Paris (December 13-14, 2013).

Cerutti, E., Claessens, S., McGuire, P., 2012, "Systemic risk in global banking: What available data can tell us and what more data are needed?" in Brunnermeier, M., Krishnamurthy, A., NBER Systemic Risk and Macro Modeling, University of Chicago Press. Cambridge, MA.

Cetorelli, N., and Goldberg, L.S., 2012, "Banking globalization and monetary transmission," Journal of Finance, Vol. LXZ11(5), pp. 1811-1843.

Cetorelli, N., Goldberg, L.S., 2011, "Global banks and international shock transmission: Evidence from the crisis," IMF Economic Review, Vol. 59, pp. 41-76.

Correa, R., H. Sapriza, and A. Zlate, 2013, "Liquidity shocks, dollar funding costs, and the bank lending channel during the European sovereign crisis," International Finance Discussion Papers No. 2012-1059, Board of Governors of the Federal Reserve System.

Culp, C. L., 2013, "Syndicated leveraged loans during and after the crisis and the role of the shadow banking system," Journal of Applied Corporate Finance, Vol. 25(2), pp. 63-85.

De Haas, R. and N. Van Horen, 2013, "Running for the exit: International bank lending during a crisis," Review of Financial Studies, Vol. 26(1), pp. 244-285.

Degryse, H., Elahi, M. A., Penas, M.F., 2010, “Cross-border exposures and financial contagion," International Review of Finance, Vol. 10, pp. 209-240.

Feenstra, R. C., Inklaar, R., and M. P. Timmer, 2013, "The next generation of the Penn World Table.” Available on www.ggdc.net/pwt (accessed May 30, 2013).

Forbes, K. and F. Warnock, 2012, "Capital flow waves: Surges, stops, flight and retrenchment," Journal of International Economics, Vol. 88(2), pp. 235-251.

Gadanecz, G., 2004, "The syndicated loan market: structure, development and implications," BIS Quarterly Review, December, pp. 75-89.

Gadanecz, G. and K. von Kleist, 2002, "Do syndicated credits anticipate BIS consolidated banking data?" BIS Quarterly Review, March, pp. 65-74.

Giannetti, M. and L. Laeven, 2012, "The flight home effect: Evidence from the syndicated loan market during financial crises," Journal of Financial Economics, Vol. 104(1), pp. 23-43.

Giannetti, M. and Y. Yafeh, 2012, "Do cultural differences between contracting parties matter? Evidence from syndicated loans," Management Science, Vol. 58(2), pp. 365-383. 
Godlewski, C. J. and L. Weill, 2008, "Syndicated loans in emerging markets," Emerging Markets Review, Vol. 9(3), pp. 206-219.

Goldberg, L. S., 2009, “Understanding banking sector globalization,” IMF Staff Papers, Vol. 56(1), pp. 171-197

Gopalan, R., Nanda, V., and Y. Yeramilli, 2011, "Does poor performance damage the reputation of financial intermediaries? Evidence from the loan syndication market," Journal of Finance, Vol. 66(6), pp. 2083-2120.

Hale, G., 2012, "Bank relationships, business cycles, and financial crises," Journal of International Economics, Vol. 88(2), pp. 312-325.

Hale, G., 2007, "Bonds or loans? The effect of macroeconomic fundamentals," Journal of International Economics, Vol. 117, pp. 196-215.

Hale, G., Kapan, T. and C. Minoiu, 2014, "Crisis transmission in the global banking network," Paper presented at the Concluding Conference of the Macro-prudential Research (MaRs) Network of the European System of Central Banks, Frankfurt (June 23-24, 2014).

Hale, G. and J. Santos, 2008, "The decision to first enter the public bond market: The role of firm reputation, funding choices, and bank relationships," Journal of Banking and Finance, Vol. 32(9), pp. 1928-1940.

Herrmann, S. and D. Mihaljek, 2013, "The determinants of cross-border bank flows to emerging markets: New empirical evidence on the spread of financial crises," Economics of Transition, Vol. 21(3), pp. 479-508.

Hoggarth, G., Mahadeva, L., and J. Martin, 2010, "Understanding international bank capital flows during the recent financial crisis," Bank of England Financial Stability Paper No. 8.

Huang, R., 2010, "How committed are bank lines of credit? Evidence from the subprime mortgage crisis," Federal Reserve Bank of Philadelphia Working Paper No. 10-25.

Kahle, K. M. and R. Stulz, 2013, "Access to capital, investment, and the financial crisis," Journal of Financial Economics, Vol. 110, pp. 280-299.

Kalemli-Ozcan, S., E. Papaioannou and J.-L. Peydro, 2013, "Financial regulation, financial globalization and the synchronization of economic activity," Journal of Finance, Vol. 68(3), pp. 1179-1228.

Kaminksy, G., 2008, "Crises and sudden stops: Evidence from international bond and syndicated loan markets," Monetary and Economic Studies, Vol. 26, pp. 107-130. 
Kapan, T. and C. Minoiu, 2013, "Balance sheet strength and bank lending during the global financial crisis," IMF Working Paper No. 13/102.

Keys, B. J., Mukherjee, T., Seru, A. and V. Vig, 2010, "Did securitization lead to lax screening? Evidence from subprime loans,” Quarterly Journal of Economics, Vol. 125, pp. 307-362.

Kiviet, J. F., 1995, “On bias, inconsistency, and efficiency of various estimators in dynamic panel data models," Journal of Econometrics, Vol. 68, pp. 53-78.

Kleimeier, S., Sander, H. and S. Heychemer, 2013, "Financial crises and cross-border banking: New evidence,” Journal of International Money and Finance, Vol. 32, pp. 884-915.

Laeven, L. and F. Valencia, 2013, "Systemic banking crises database," IMF Economic Review, Vol. 61(2), pp. 225-270.

Lane, P. R., and G.-M. Milesi-Ferretti, 2008, “The drivers of financial globalization," American Economic Review, Papers and Proceedings, Vol. 98(2), pp. 327-332.

Lee, S., and D. Mullineaux, 2004, "Monitoring, financial distress, and the structure of commercial lending syndicates,” Financial Management, Vol. 33, pp. 107-130.

Martin, P. and H. Rey, 2004, "Financial super-markets: Size matters for asset trade," Journal of International Economics, Vol. 64(2), pp. 335-361.

Mayer, T. and S. Zignago, 2011, "Notes on CEPII's distance measures: The Geodist database," CEPII Working Paper 2011-25.

Milesi-Ferretti, G.-M. and C. Tille, 2011, "The great retrenchment: International capital flows during the global financial crisis," Economic Policy, Vol. 26(66), pp. 289-346.

Minoiu, C. and J. Reyes, 2013, “A network analysis of global banking: 1978-2010,” Journal of Financial Stability, Vol. 9(2), pp. 168-184.

Nandy, D. K. and P. Shao, 2010, "Institutional investment in syndicated loans," European Finance Association 2009 Bergen Meetings Paper.

Nini, G., 2008, "How non-banks increased the supply of bank loans: Evidence from institutional term loans," mimeo, The Wharton School, University of Pennsylvania.

Peydro, J.-L., 2010, Discussion of "The effects of bank capital on lending: What do we know, and what does it mean?” International Journal of Central Banking, Vol. 6(4), pp. 55-69.

Pichler, P. and W. Wilhelm, 2001, "A theory of the syndicate: Form follows function," Journal of Finance, Vol. 50(4), pp. 1113-1146. 
Portes, R. and H. Rey, 2005, “The determinants of cross-border equity flows," Journal of International Economics, Vol. 65, pp. 269-296.

Quinn, D., M. Schindler, and A. M. Toyoda, 2011, "Assessing measures of financial integration and openness," IMF Economic Review, Vol. 59(3), pp. 488-523.

Simons, K., 1993, “Why do banks syndicate loans?” New England Economic Review, pp. 45-52.

Sufi, A., 2007, "Information asymmetry and financing arrangements: Evidence from syndicated loans," Journal of Finance, Vol. 62, pp. 629-668.

Tucker, A., Madura, J. and T. Chiang, 1991, International Financial Markets, St. Paul, Minnesota: West Publishing Company.

Van Rijckeghem, C. and B. Weder, 2003, "Spillovers through banking centers: A panel data analysis of bank flows," Journal of International Money and Finance, Vol. 22(4), pp. 483-509.

World Bank, 2013, Global Financial Development Database (GFDD), April. Available on http://go.worldbank.org/AWACYAMMM0 (accessed May 30, 2013). 
Tables and figures

Figure 1. Syndicated vs. total loan exposures (trillions of U.S. dollars)

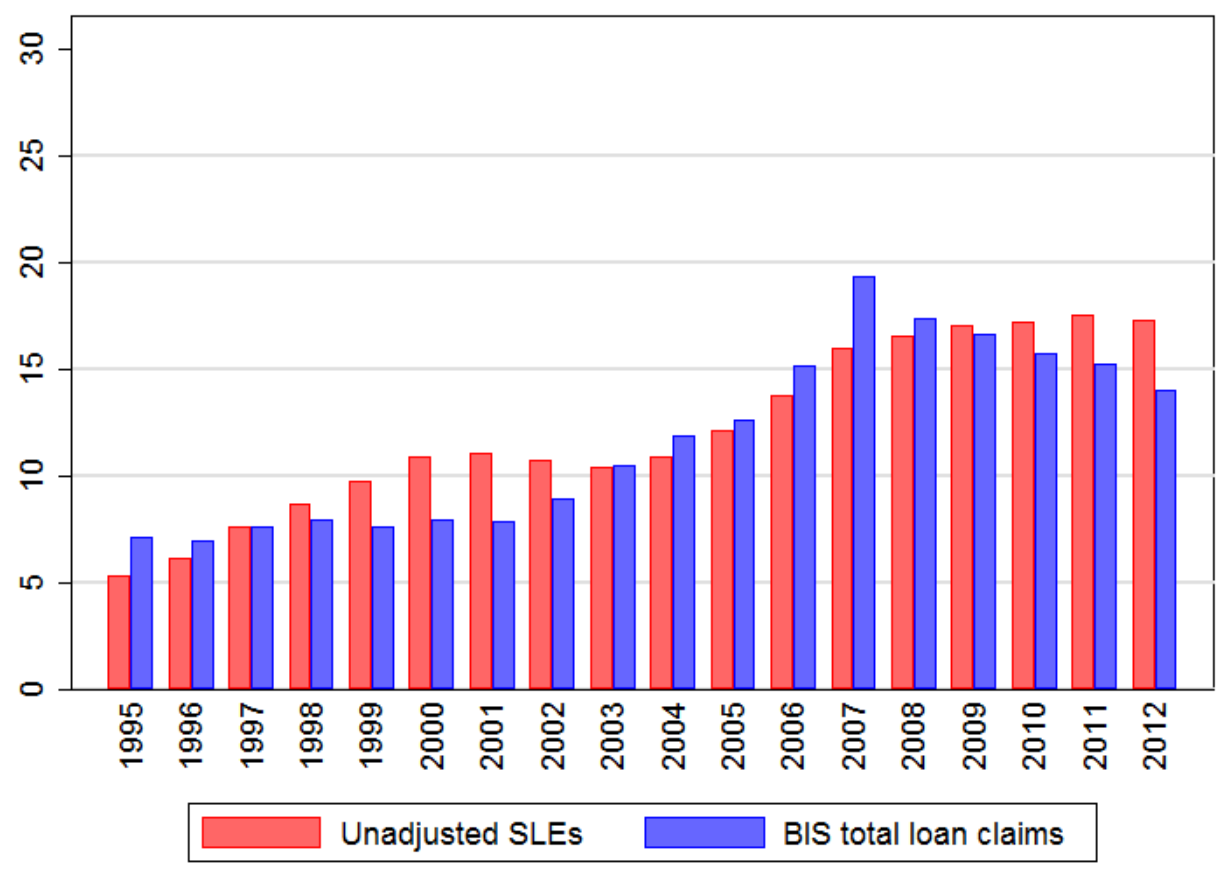

Notes: The figure depicts unadjusted SLEs vs. BIS loan claims during 1995-2012. All figures are expressed in trillions of constant U.S. dollars (2005 prices). Sources: Dealogic Loan Analytics, BIS locational banking statistics (Table 7A). 
Figure 2. Syndicated vs. non-syndicated loan exposures (trillions of U.S. dollars)

\section{A. All borrowers}

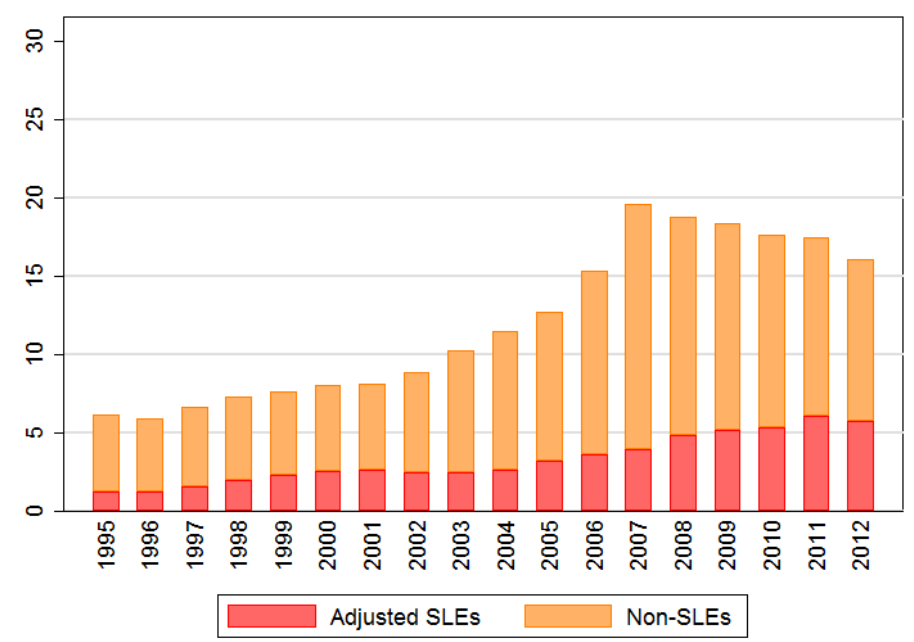

B. Advanced economy borrowers

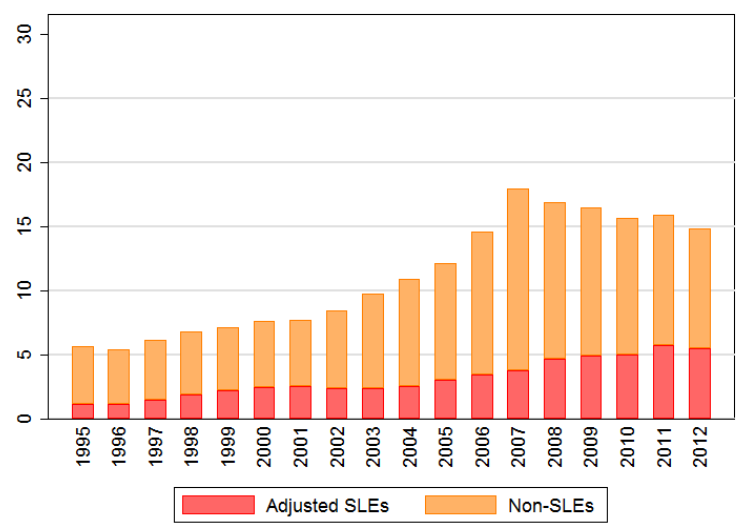

C. Emerging market borrowers

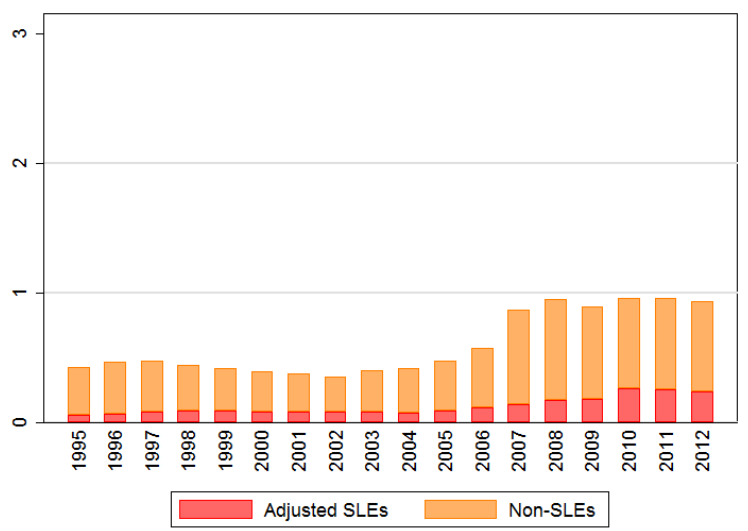

Notes: The figure depicts adjusted SLEs vs. non-SLEs during 1995-2012 for all borrowing countries (A), advanced economy borrowers (B), and emerging market borrowers (C). SLEs are adjusted for maximum comparability with the BIS loan claims (see text for details). All figures are expressed in trillions of constant U.S. dollars (2005 prices). Sources: Dealogic Loan Analytics, BIS locational banking statistics, and authors' calculations. 
Table 1. List of countries in the sample

\begin{tabular}{|c|c|c|c|}
\hline \multirow{2}{*}{$\begin{array}{l}\text { Creditor banking system countries } \\
\text { Advanced economies }\end{array}$} & \multicolumn{3}{|l|}{ Debtor countries } \\
\hline & Advanced economies & \multicolumn{2}{|c|}{ Emerging market economies } \\
\hline$\overline{\text { Australia }}$ & $\overline{\text { Australia }}$ & Albania & Peru \\
\hline Austria & Austria & Argentina & Philippines \\
\hline Belgium & Belgium & Belarus & Poland \\
\hline Canada & Canada & Brazil & Russia \\
\hline Denmark & Czech Republic & Bulgaria & South Africa \\
\hline Finland & Denmark & Chile & Sri Lanka \\
\hline France & Estonia & China & Thailand \\
\hline Germany & Finland & Colombia & Tunisia \\
\hline Greece & France & Costa Rica & Turkey \\
\hline Ireland & Germany & Croatia & Ukraine \\
\hline Italy & Greece & Ecuador & Uruguay \\
\hline Japan & Ireland & Egypt & Venezuela, Rep. Bol. \\
\hline Luxembourg & Israel & El Salvador & Vietnam \\
\hline Netherlands & Italy & Guatemala & \\
\hline Portugal & Japan & Hungary & \\
\hline Spain & Luxembourg & India & \\
\hline Sweden & Netherlands & Indonesia & \\
\hline Switzerland & New Zealand & Jamaica & \\
\hline United Kingdom & Norway & Jordan & \\
\hline \multirow[t]{2}{*}{ United States } & Portugal & Kazakhstan & \\
\hline & Singapore & Latvia & \\
\hline Emerging market economies & Slovak Republic & Lebanon & \\
\hline Brazil & Slovenia & Lithuania & \\
\hline Chile & South Korea & Malaysia & \\
\hline India & Spain & Mexico & \\
\hline Mexico & Sweden & Morocco & \\
\hline Panama & Switzerland & Pakistan & \\
\hline Turkey & United Kingdom & Panama & \\
\hline
\end{tabular}

Notes: The table lists the 26 lender countries and 76 borrower countries in our baseline regression sample. Countries are classified as advanced or emerging market economies according to the IMF World Economic Outlook, September 2013. 


\section{Table 2. Variable sources and definitions}

\begin{tabular}{|c|c|c|}
\hline Variable & Description & Source \\
\hline \multicolumn{3}{|l|}{ A. Cross-border bank exposures } \\
\hline Syndicated loan exposures (SLE) & $\begin{array}{l}\text { Computed from loan-level data on syndicated loan deals using information on deal amount } \\
\text { and maturity. Expressed in constant terms using US CPI. }\end{array}$ & $\begin{array}{l}\text { Authors' calculations using Dealogic } \\
\text { Loan Analytics and IMF's INS database } \\
\text { for US CPI. }\end{array}$ \\
\hline BIS international banking statistics & $\begin{array}{l}\text { Total claims of banking systems of BIS reporting countries vis-à-vis residents in other } \\
\text { countries, aggregated on a locational or consolidated basis. See Appendix for details. } \\
\text { Expressed in constant terms using US CPI. }\end{array}$ & $\begin{array}{l}\text { BIS locational and consolidated banking } \\
\text { statistics and IMF's INS database for US } \\
\text { CPI. }\end{array}$ \\
\hline $\begin{array}{l}\text { Non-syndicated loan exposures } \\
\text { (non-SLE) }\end{array}$ & $\begin{array}{l}\text { Computed as the difference between total loan claims of baking systems of BIS reporting } \\
\text { countries, on a locational basis, and syndicated loan exposures. }\end{array}$ & Authors' calculations. \\
\hline \multicolumn{3}{|l|}{ B. Regression variables } \\
\hline \multicolumn{3}{|l|}{ Within-pair } \\
\hline$\overline{\text { Log-real (bilateral) trade }}$ & The sum of total exports and imports. & UN-COMTRADE \\
\hline 1: Common language & $\begin{array}{l}\text { Indicator for same language spoken in the two countries. Available for download on: } \\
\text { http://www.cepii.fr/anglaisgraph/bdd/distances.htm }\end{array}$ & Mayer and Zignago (2011) \\
\hline Geographical distance & $\begin{array}{l}\text { Distance (in km) between the capital cities of the two countries. Available for download on: } \\
\text { http://www.cepii.fr/anglaisgraph/bdd/distances.htm }\end{array}$ & Mayer and Zignago (2011) \\
\hline 1: Foreign affiliate & $\begin{array}{l}\text { Indicator for the presence of bank affiliate(s) of country i in host country j in at least one } \\
\text { quarter of each year. Constructed using affiliates' claims data for country pairs } i-j \text { in the BIS } \\
\text { consolidated statistics (both immediate risk and ultimate risk basis). }\end{array}$ & $\begin{array}{l}\text { Authors' calculations using BIS } \\
\text { consolidated banking statistics. }\end{array}$ \\
\hline \multicolumn{3}{|l|}{ Country characteristics } \\
\hline Bank assets (\% GDP) & $\begin{array}{l}\text { Total assets held by deposit money banks as a share of GDP. Assets include claims on } \\
\text { domestic real nonfinancial sector which includes central, state and local governments, } \\
\text { nonfinancial public enterprises and private sector. Deposit money banks comprise } \\
\text { commercial banks and other financial institutions that accept transferable deposits, such as } \\
\text { demand deposits. }\end{array}$ & $\begin{array}{l}\text { Global Financial Development Database } \\
\text { (World Bank, 2013), April. }\end{array}$ \\
\hline Bank capital-to-assets ratio & $\begin{array}{l}\text { Ratio of bank capital and reserves to total assets. Capital and reserves include funds } \\
\text { contributed by owners, retained earnings, general and special reserves, provisions, and } \\
\text { valuation adjustments. Capital includes tier } 1 \text { capital and total regulatory capital. Total assets } \\
\text { include all nonfinancial and financial assets. }\end{array}$ & $\begin{array}{l}\text { Global Financial Development Database } \\
\text { (World Bank, 2013), April. }\end{array}$ \\
\hline Capital account openness & $\begin{array}{l}\text { Degree of openness of the capital account, on a scale from } 0 \text { to } 100 . \text { Higher values } \\
\text { represent greater openness }\end{array}$ & Quinn, Schindler and Toyoda (2011) \\
\hline Exchange rate volatility & Computed as the yearly standard deviation of monthly nominal exchange rates. & $\begin{array}{l}\text { IMF's International Financial Statistics } \\
\text { (IFS) }\end{array}$ \\
\hline Institutional quality & $\begin{array}{l}\text { Polity IV score on a scale from }-10 \text { (autocracy) to }+10 \text { (democracy). Available for download } \\
\text { on: http://www.systemicpeace.org/inscrdata.html }\end{array}$ & $\begin{array}{l}\text { Polity IV project: Political Regime } \\
\text { Characteristics and Transitions, } \\
1800-2008 .\end{array}$ \\
\hline Internationally-rated banks (\%) & $\begin{array}{l}\text { Percentage of domestic banks that are rated by one of the three leading credit rating } \\
\text { agencies (Moody's, Standard \& Poor's, or Fitch). }\end{array}$ & $\begin{array}{l}\text { Global Financial Development Database } \\
\text { (World Bank, 2013), April. }\end{array}$ \\
\hline Liquid assets & $\begin{array}{l}\text { The ratio of the value of liquid assets (easily converted to cash) to short-term funding plus } \\
\text { total deposits. Liquid assets include cash and due from banks, trading securities and at fair } \\
\text { value through income, loans and advances to banks, reverse repos and cash collaterals. } \\
\text { Deposits and short term funding includes total customer deposits (current, savings and } \\
\text { term) and short term borrowing (money market instruments, CDs and other deposits). }\end{array}$ & Bankscope \\
\hline $\begin{array}{l}\text { Loan loss reserves (\% gross } \\
\text { loans) }\end{array}$ & $\begin{array}{l}\text { Valuation reserves against a bank's total loans on the balance sheet, representing the } \\
\text { amount the banks thinks is adequate to cover estimated losses in the loan portfolio. } \\
\text { Computed as percentage of gross loans outstanding minus earned income and loan loss } \\
\text { reserves for charged-off loans. }\end{array}$ & Bankscope \\
\hline Net charge-offs (\% gross loans) & $\begin{array}{l}\text { Gross amount of loans charged off as bad debt minus recoveries collected from earlier } \\
\text { charge-offs. }\end{array}$ & Bankscope \\
\hline Net interest margin & $\begin{array}{l}\text { Accounting value of bank's net interest revenue as a share of its average interest-bearing } \\
\text { (total earning) assets. }\end{array}$ & Bankscope \\
\hline Per capita income & Per capita GDP (computed as RGDPE/POP) & $\begin{array}{l}\text { Penn World Tables } 8.0 \text { (Feenstra, } \\
\text { Inklaar, and Timmer, 2013). }\end{array}$ \\
\hline Return on assets & Commercial banks' net income to yearly averaged total assets. & Bankscope \\
\hline S\&P sovereign credit rating & Soveregin credit rating by Standard \& Poor's at end-year. & Standard \& Poor's \\
\hline $\begin{array}{l}\text { Stock market capitalization ( } \% \\
\text { GDP) }\end{array}$ & Total value of all listed shares in a stock market as a percentage of GDP. & $\begin{array}{l}\text { Global Financial Development Database } \\
\text { (World Bank, 2013), April. }\end{array}$ \\
\hline Stock market return volatility & $\begin{array}{l}\text { Volatility of stock market returns is the } x \text {-year standard deviation of the return on the } \\
\text { S\&P/IFCG (RI) index. Detailed description o the index: } \\
\text { http://www.russell.com/us/glossary/indexes/s\&p ifc emerging markets indexes.htm. }\end{array}$ & Datastream Advance \\
\hline
\end{tabular}


Table 3. Descriptive statistics

\begin{tabular}{|c|c|c|c|c|c|c|c|c|}
\hline & Obs. & Mean & St. Dev. & Min & P25 & P50 & P75 & $\operatorname{Max}$ \\
\hline \multicolumn{9}{|l|}{ A. Cross-border bank exposures } \\
\hline BIS claims (total) & 9,213 & 4331.40 & 4331.40 & 0.92 & 168.50 & 762.88 & 3081.97 & 149440.35 \\
\hline BIS claims (loans) & 9,213 & 17088.12 & 17088.12 & 0.90 & 346.30 & 1913.31 & 9699.00 & 1035620.00 \\
\hline SLE (total, unadjusted) & 9,213 & 12678.98 & 12678.98 & 0.90 & 250.88 & 1275.82 & 6333.66 & 1032253.90 \\
\hline SLE (total, adjusted) & 9,213 & 1134.77 & 1134.77 & 0.03 & 17.12 & 102.97 & 628.61 & 60363.54 \\
\hline SLE (credit lines, adjusted) & 9,213 & 954.00 & 954.00 & 0.00 & 5.66 & 72.56 & 522.69 & 55141.15 \\
\hline SLE (term loans, adjusted) & 9,213 & 180.77 & 180.77 & 0.00 & 0.00 & 4.19 & 54.56 & 13179.62 \\
\hline \multicolumn{9}{|l|}{ B. Regression variables } \\
\hline \multicolumn{9}{|l|}{ Within-pair } \\
\hline Log-SLE & 9,213 & 3.44 & 1.93 & 0.08 & 1.95 & 3.14 & 4.76 & 9.58 \\
\hline Log-non-SLE & 9,213 & 5.86 & 2.41 & 0.00 & 4.04 & 5.92 & 7.55 & 12.41 \\
\hline Log-real (bilateral) trade & 9,213 & 7.06 & 2.26 & 0.00 & 5.90 & 7.35 & 8.56 & 12.77 \\
\hline 1: Common language & 9,213 & 0.13 & 0.34 & 0.00 & 0.00 & 0.00 & - & 1.00 \\
\hline Log-geographical distance & 9,213 & 8.18 & 1.08 & 4.09 & 7.33 & 8.40 & 9.11 & 9.88 \\
\hline 1: Foreign affiliate & 9,213 & 0.39 & 0.49 & 0.00 & 0.00 & 0.00 & - & 1.00 \\
\hline \multicolumn{9}{|l|}{ Lender characteristics } \\
\hline Log-per capita GDP & 9,213 & 9.90 & 0.63 & 7.65 & 9.74 & 10.09 & 10.22 & 10.73 \\
\hline Bank assets (\% GDP) & 9,213 & 89.97 & 46.85 & 26.28 & 58.40 & 85.49 & 106.35 & 245.07 \\
\hline Bank capital-to-asset ratio & 9,213 & 6.33 & 2.39 & 2.40 & 4.90 & 6.00 & 7.00 & 13.40 \\
\hline Net interest margin & 8,464 & 4.90 & 3.39 & 2.13 & 2.34 & 3.88 & 5.23 & 11.19 \\
\hline Liquid assets (\% deposits and ST funding) & 8,464 & 43.60 & 21.22 & 13.80 & 27.51 & 38.22 & 56.76 & 78.30 \\
\hline Return on assets & 8,464 & 1.11 & 0.97 & -0.09 & 0.40 & 1.09 & 1.45 & 3.37 \\
\hline Loan loss reserves (\% gross loans) & 8,363 & 3.80 & 2.40 & 1.39 & 2.31 & 2.91 & 5.47 & 8.90 \\
\hline Net charge-offs (\% gross loans) & 7,185 & 1.14 & 0.79 & 0.20 & 0.34 & 1.09 & 1.67 & 2.55 \\
\hline \multicolumn{9}{|l|}{ Borrower characteristics } \\
\hline Log-per capita GDP & 9,213 & 9.42 & 0.86 & 6.90 & 8.77 & 9.45 & 10.19 & 11.27 \\
\hline Bank assets (\% GDP) & 9,213 & 74.33 & 47.30 & 4.93 & 31.67 & 69.79 & 104.73 & 187.44 \\
\hline Institutional quality & 9,213 & 5.92 & 6.11 & -10.00 & 6.00 & 9.00 & 10.00 & 10.00 \\
\hline Capital account openness & 9,213 & 77.96 & 25.48 & 25.00 & 50.00 & 87.50 & 100.00 & 100.00 \\
\hline Exchange rate volatilty & 6,654 & 7.15 & 23.27 & 0.00 & 0.02 & 0.16 & 1.49 & 141.15 \\
\hline Stock market capitalization ( $\%$ GDP) & 9,000 & 58.44 & 51.78 & 0.62 & 22.11 & 40.22 & 80.68 & 238.91 \\
\hline Stock market return volatility & 3,042 & 184.98 & 358.91 & 6.28 & 31.90 & 74.85 & 199.75 & 1617.70 \\
\hline S\&P Sovereign credit rating & 8,801 & 19.76 & 14.67 & 1.00 & 3.00 & 19.00 & 30.00 & 60.00 \\
\hline$\%$ internationally-rated banks & 7,549 & 68.10 & 32.42 & 0.00 & 50.00 & 80.00 & 100.00 & 100.00 \\
\hline
\end{tabular}

Notes: The table reports summary statistics for selected variables used in the empirical analysis. The summary statistics are computed for the regression sample (corresponding to column 1 in Table 4). All aggregates in Panel A are expressed in millions of constant U.S. dollars (2005 prices). See Table 2 for variable definitions and sources. 
Table 4. Drivers of syndicated and non-syndicated loan exposures - Baseline

\begin{tabular}{|c|c|c|c|c|c|c|}
\hline \multirow[b]{4}{*}{ Within-pair } & $(1)$ & $(2)$ & (3) & (4) & $(5)$ & (6) \\
\hline & \multicolumn{3}{|c|}{ Dependent variable: Log-SLE } & \multicolumn{3}{|c|}{ Dependent variable: Log-non-SLE } \\
\hline & Full & $\begin{array}{c}\mathrm{AE} \\
\text { borrowers } \\
\end{array}$ & $\begin{array}{c}\text { EME } \\
\text { borrowers }\end{array}$ & Full & $\begin{array}{c}\mathrm{AE} \\
\text { borrowers } \\
\end{array}$ & $\begin{array}{c}\text { EME } \\
\text { borrowers }\end{array}$ \\
\hline & & & & & & \\
\hline Log-real trade & $\begin{array}{c}0.241^{* * *} \\
(0.030)\end{array}$ & $\begin{array}{c}0.203^{\star * *} \\
(0.034)\end{array}$ & $\begin{array}{c}0.229^{* \star *} \\
(0.070)\end{array}$ & $\begin{array}{c}0.256^{\star \star *} \\
(0.039)\end{array}$ & $\begin{array}{c}0.159^{\star * *} \\
(0.038)\end{array}$ & $\begin{array}{c}0.433^{* * *} \\
(0.069)\end{array}$ \\
\hline 1: Common language & $\begin{array}{c}0.305^{\star * *} \\
(0.100)\end{array}$ & $\begin{array}{c}0.196^{*} \\
(0.112)\end{array}$ & $\begin{array}{c}0.541^{* * *} \\
(0.186)\end{array}$ & $\begin{array}{c}0.161 \\
(0.109)\end{array}$ & $\begin{array}{c}0.058 \\
(0.145)\end{array}$ & $\begin{array}{c}0.612^{\star * *} \\
(0.155)\end{array}$ \\
\hline Log-geographical distance & $\begin{array}{c}-0.405^{\star * *} \\
(0.057)\end{array}$ & $\begin{array}{c}-0.553^{* * *} \\
(0.079)\end{array}$ & $\begin{array}{c}-0.509^{* * *} \\
(0.136)\end{array}$ & $\begin{array}{c}-0.777^{* * *} \\
(0.065)\end{array}$ & $\begin{array}{c}-0.876^{* * *} \\
(0.086)\end{array}$ & $\begin{array}{c}-0.854^{* * *} \\
(0.121)\end{array}$ \\
\hline 1: Foreign affiliate & $\begin{array}{c}0.525^{\star \star *} \\
(0.062) \\
\end{array}$ & $\begin{array}{c}0.405^{\star \star \star} \\
(0.078) \\
\end{array}$ & $\begin{array}{c}0.465^{\star \star \star} \\
(0.097) \\
\end{array}$ & $\begin{array}{c}0.753^{* * *} \\
(0.068) \\
\end{array}$ & $\begin{array}{c}0.744^{* * *} \\
(0.098) \\
\end{array}$ & $\begin{array}{c}0.582^{* * *} \\
(0.089) \\
\end{array}$ \\
\hline \multicolumn{7}{|l|}{ Lender characteristics } \\
\hline Log-per capita GDP & $\begin{array}{l}-0.452 \\
(0.324)\end{array}$ & $\begin{array}{l}-0.247 \\
(0.450)\end{array}$ & $\begin{array}{l}-0.550 \\
(0.474)\end{array}$ & $\begin{array}{c}0.079 \\
(0.330)\end{array}$ & $\begin{array}{c}0.407 \\
(0.398)\end{array}$ & $\begin{array}{l}-0.359 \\
(0.516)\end{array}$ \\
\hline Bank assets (\% GDP) & $\begin{array}{l}-0.000 \\
(0.001)\end{array}$ & $\begin{array}{c}-0.000 \\
(0.001)\end{array}$ & $\begin{array}{c}0.000 \\
(0.001)\end{array}$ & $\begin{array}{l}-0.000 \\
(0.001)\end{array}$ & $\begin{array}{l}-0.001 \\
(0.001)\end{array}$ & $\begin{array}{l}0.002^{*} \\
(0.001)\end{array}$ \\
\hline Bank capital-to-assets ratio & $\begin{array}{c}-0.049^{* * *} \\
(0.015)\end{array}$ & $\begin{array}{c}-0.055^{\star * *} \\
(0.020)\end{array}$ & $\begin{array}{c}-0.048^{\star *} \\
(0.022)\end{array}$ & $\begin{array}{l}-0.010 \\
(0.018)\end{array}$ & $\begin{array}{c}0.016 \\
(0.023)\end{array}$ & $\begin{array}{l}0.049^{*} \\
(0.025)\end{array}$ \\
\hline Log-total other lending & $\begin{array}{c}0.617^{\star \star \star} \\
(0.030) \\
\end{array}$ & $\begin{array}{c}0.651^{\star \star *} \\
(0.055) \\
\end{array}$ & $\begin{array}{c}0.592^{\star \star \star} \\
(0.037) \\
\end{array}$ & $\begin{array}{c}0.034 \\
(0.041) \\
\end{array}$ & $\begin{array}{c}-0.128^{\star *} \\
(0.060) \\
\end{array}$ & $\begin{array}{c}0.181^{* * *} \\
(0.045) \\
\end{array}$ \\
\hline \multicolumn{7}{|l|}{ Borrower characteristics } \\
\hline Log-per capita GDP & $\begin{array}{l}-0.105 \\
(0.197)\end{array}$ & $\begin{array}{l}-0.852^{*} \\
(0.472)\end{array}$ & $\begin{array}{l}-0.052 \\
(0.296)\end{array}$ & $\begin{array}{c}0.704^{\star * *} \\
(0.192)\end{array}$ & $\begin{array}{c}1.719^{\star * *} \\
(0.578)\end{array}$ & $\begin{array}{c}0.080 \\
(0.280)\end{array}$ \\
\hline Bank assets (\% GDP) & $\begin{array}{l}0.002^{\star \star} \\
(0.001)\end{array}$ & $\begin{array}{c}0.001 \\
(0.001)\end{array}$ & $\begin{array}{c}0.003 \\
(0.002)\end{array}$ & $\begin{array}{c}0.006^{\star * *} \\
(0.001)\end{array}$ & $\begin{array}{c}0.004^{\star \star \star} \\
(0.001)\end{array}$ & $\begin{array}{c}0.008^{\star * *} \\
(0.002)\end{array}$ \\
\hline Institutional quality & $\begin{array}{c}0.009 \\
(0.012)\end{array}$ & $\begin{array}{c}0.006 \\
(0.065)\end{array}$ & $\begin{array}{l}0.025^{* *} \\
(0.011)\end{array}$ & $\begin{array}{c}0.005 \\
(0.012)\end{array}$ & $\begin{array}{c}0.135 \\
(0.086)\end{array}$ & $\begin{array}{c}0.013 \\
(0.012)\end{array}$ \\
\hline Capital account openness & $\begin{array}{c}0.002 \\
(0.002)\end{array}$ & $\begin{array}{c}0.004 \\
(0.005)\end{array}$ & $\begin{array}{c}0.002 \\
(0.002)\end{array}$ & $\begin{array}{c}0.009^{\star * *} \\
(0.002)\end{array}$ & $\begin{array}{l}-0.004 \\
(0.005)\end{array}$ & $\begin{array}{c}0.009^{\star * *} \\
(0.002)\end{array}$ \\
\hline Log-total other borrowing & $\begin{array}{l}0.107^{\star * *} \\
(0.038)\end{array}$ & $\begin{array}{l}0.193^{\star \star *} \\
(0.053)\end{array}$ & $\begin{array}{c}0.075 \\
(0.049) \\
\end{array}$ & $\begin{array}{c}0.075 \\
(0.067) \\
\end{array}$ & $\begin{array}{c}0.008 \\
(0.097)\end{array}$ & $\begin{array}{c}0.130 \\
(0.091) \\
\end{array}$ \\
\hline Observations & 9,213 & 4,601 & 4,200 & 9,213 & 4,601 & 4,200 \\
\hline R-squared & 0.811 & 0.853 & 0.748 & 0.786 & 0.762 & 0.717 \\
\hline
\end{tabular}

Notes: The dependent variable is log-SLE (columns 1-3) and log-non-SLE (columns 4-6). Sample period: 1995-2012. All regressions include country and year fixed effects. Standard errors are clustered on country pair. See Table 2 for variable definitions and sources. 
Table 5. Drivers of syndicated and non-syndicated loan exposures - Interactions with indicator for global financial crisis

\begin{tabular}{|c|c|c|c|c|c|c|c|c|c|c|c|c|}
\hline & (1) & (2) & (3) & (4) & (5) & (6) & (7) & (8) & (9) & $(10)$ & (11) & (12) \\
\hline & \multicolumn{6}{|c|}{ Dependent variable: Log-SLE } & \multicolumn{6}{|c|}{ Dependent variable: Log-non-SLE } \\
\hline & Full & Full & Full & Full & Full & Full & Full & Full & Full & Full & Full & Full \\
\hline \multicolumn{13}{|l|}{ Within-pair } \\
\hline Log-real trade & $\begin{array}{c}0.230^{\star \star \star} \\
(0.030)\end{array}$ & $\begin{array}{c}0.239^{\star \star *} \\
(0.030)\end{array}$ & $\begin{array}{c}0.241^{\star \star *} \\
(0.030)\end{array}$ & $\begin{array}{c}0.241^{\star \star \star} \\
(0.030)\end{array}$ & $\begin{array}{c}0.242^{\star \star \star} \\
(0.030)\end{array}$ & $\begin{array}{c}0.230^{\star \star *} \\
(0.030)\end{array}$ & $\begin{array}{c}0.246^{\star \star *} \\
(0.038)\end{array}$ & $\begin{array}{c}0.253^{\star \star \star} \\
(0.039)\end{array}$ & $\begin{array}{c}0.256^{\star \star \star} \\
(0.039)\end{array}$ & $\begin{array}{c}0.254^{\star \star \star} \\
(0.039)\end{array}$ & $\begin{array}{c}0.256^{\star * *} \\
(0.039)\end{array}$ & $\begin{array}{c}0.245^{\star \star *} \\
(0.039)\end{array}$ \\
\hline 1: Common language & $\begin{array}{c}0.303^{* * *} \\
(0.100)\end{array}$ & $\begin{array}{c}0.308^{* * *} \\
(0.100)\end{array}$ & $\begin{array}{c}0.305^{\star \star *} \\
(0.100)\end{array}$ & $\begin{array}{c}0.307^{\star * *} \\
(0.100)\end{array}$ & $\begin{array}{c}0.304^{\star * *} \\
(0.100)\end{array}$ & $\begin{array}{c}0.305^{\star \star \star} \\
(0.100)\end{array}$ & $\begin{array}{c}0.160 \\
(0.109)\end{array}$ & $\begin{array}{c}0.165 \\
(0.109)\end{array}$ & $\begin{array}{c}0.161 \\
(0.109)\end{array}$ & $\begin{array}{c}0.163 \\
(0.109)\end{array}$ & $\begin{array}{c}0.161 \\
(0.109)\end{array}$ & $\begin{array}{c}0.162 \\
(0.109)\end{array}$ \\
\hline Log-geographical distance & $\begin{array}{c}-0.392^{* * *} \\
(0.057)\end{array}$ & $\begin{array}{c}-0.384^{\star \star *} \\
(0.057)\end{array}$ & $\begin{array}{c}-0.405^{\star \star \star} \\
(0.057)\end{array}$ & $\begin{array}{c}-0.406^{* * *} \\
(0.057)\end{array}$ & $\begin{array}{c}-0.404^{* * *} \\
(0.057)\end{array}$ & $\begin{array}{c}-0.392^{\star * *} \\
(0.058)\end{array}$ & $\begin{array}{c}-0.765^{\star * *} \\
(0.064)\end{array}$ & $\begin{array}{c}-0.751^{* * *} \\
(0.066)\end{array}$ & $\begin{array}{c}-0.777^{\star * *} \\
(0.065)\end{array}$ & $\begin{array}{c}-0.779^{* \star *} \\
(0.065)\end{array}$ & $\begin{array}{c}-0.777^{\star * *} \\
(0.065)\end{array}$ & $\begin{array}{c}-0.759^{\star \star \star} \\
(0.065)\end{array}$ \\
\hline 1: Foreign affiliate & $\begin{array}{c}0.523^{\star \star *} \\
(0.062)\end{array}$ & $\begin{array}{c}0.519^{\star * *} \\
(0.062)\end{array}$ & $\begin{array}{c}0.525^{\star \star *} \\
(0.062)\end{array}$ & $\begin{array}{c}0.520^{* * *} \\
(0.062) \\
\end{array}$ & $\begin{array}{c}0.523^{* \star *} \\
(0.062)\end{array}$ & $\begin{array}{c}0.518^{\star \star *} \\
(0.062)\end{array}$ & $\begin{array}{c}0.752^{* * *} \\
(0.068) \\
\end{array}$ & $\begin{array}{c}0.746^{\star * *} \\
(0.068) \\
\end{array}$ & $\begin{array}{c}0.753^{* * *} \\
(0.068) \\
\end{array}$ & $\begin{array}{c}0.746^{* * *} \\
(0.068) \\
\end{array}$ & $\begin{array}{c}0.749^{* * *} \\
(0.068)\end{array}$ & $\begin{array}{c}0.743^{* * *} \\
(0.068) \\
\end{array}$ \\
\hline \multicolumn{13}{|l|}{ Lender characteristics } \\
\hline Log-per capita GDP & $\begin{array}{l}-0.250 \\
(0.322)\end{array}$ & $\begin{array}{l}-0.502 \\
(0.323)\end{array}$ & $\begin{array}{l}-0.449 \\
(0.324)\end{array}$ & $\begin{array}{l}-0.450 \\
(0.322)\end{array}$ & $\begin{array}{l}-0.458 \\
(0.324)\end{array}$ & $\begin{array}{l}-0.274 \\
(0.323)\end{array}$ & $\begin{array}{c}0.262 \\
(0.330)\end{array}$ & $\begin{array}{c}0.024 \\
(0.331)\end{array}$ & $\begin{array}{c}0.089 \\
(0.330)\end{array}$ & $\begin{array}{c}0.087 \\
(0.330)\end{array}$ & $\begin{array}{c}0.073 \\
(0.331)\end{array}$ & $\begin{array}{c}0.218 \\
(0.332)\end{array}$ \\
\hline Bank assets (\% GDP) & $\begin{array}{c}0.000 \\
(0.001)\end{array}$ & $\begin{array}{l}-0.000 \\
(0.001)\end{array}$ & $\begin{array}{l}-0.000 \\
(0.001)\end{array}$ & $\begin{array}{l}-0.000 \\
(0.001)\end{array}$ & $\begin{array}{l}-0.000 \\
(0.001)\end{array}$ & $\begin{array}{c}0.000 \\
(0.001)\end{array}$ & $\begin{array}{c}0.000 \\
(0.001)\end{array}$ & $\begin{array}{l}-0.000 \\
(0.001)\end{array}$ & $\begin{array}{l}-0.000 \\
(0.001)\end{array}$ & $\begin{array}{l}-0.000 \\
(0.001)\end{array}$ & $\begin{array}{l}-0.000 \\
(0.001)\end{array}$ & $\begin{array}{c}0.000 \\
(0.001)\end{array}$ \\
\hline Bank capital-to-assets ratio & $\begin{array}{c}-0.046^{* \star *} \\
(0.015)\end{array}$ & $\begin{array}{c}-0.046^{\star \star *} \\
(0.015)\end{array}$ & $\begin{array}{c}-0.051^{\star * \star} \\
(0.016)\end{array}$ & $\begin{array}{c}-0.048^{* * *} \\
(0.015)\end{array}$ & $\begin{array}{c}-0.049^{* * *} \\
(0.015)\end{array}$ & $\begin{array}{c}-0.045^{\star * *} \\
(0.015)\end{array}$ & $\begin{array}{l}-0.008 \\
(0.017)\end{array}$ & $\begin{array}{l}-0.007 \\
(0.017)\end{array}$ & $\begin{array}{l}-0.016 \\
(0.018)\end{array}$ & $\begin{array}{l}-0.009 \\
(0.018)\end{array}$ & $\begin{array}{l}-0.010 \\
(0.018)\end{array}$ & $\begin{array}{l}-0.011 \\
(0.018)\end{array}$ \\
\hline Log-total other lending & $\begin{array}{c}0.620^{\star \star \star} \\
(0.031)\end{array}$ & $\begin{array}{c}0.612^{\star \star *} \\
(0.030)\end{array}$ & $\begin{array}{c}0.617^{\star * \star} \\
(0.030)\end{array}$ & $\begin{array}{c}0.610^{\star * *} \\
(0.030)\end{array}$ & $\begin{array}{c}0.612^{\star * *} \\
(0.030)\end{array}$ & $\begin{array}{c}0.612^{\star \star \star} \\
(0.030)\end{array}$ & $\begin{array}{c}0.035 \\
(0.042)\end{array}$ & $\begin{array}{c}0.027 \\
(0.039)\end{array}$ & $\begin{array}{c}0.035 \\
(0.041)\end{array}$ & $\begin{array}{c}0.017 \\
(0.040)\end{array}$ & $\begin{array}{c}0.022 \\
(0.040)\end{array}$ & $\begin{array}{c}0.017 \\
(0.041)\end{array}$ \\
\hline \multicolumn{13}{|l|}{ Borrower characteristics } \\
\hline Log-per capita GDP & $\begin{array}{l}-0.044 \\
(0.198)\end{array}$ & $\begin{array}{l}-0.077 \\
(0.196)\end{array}$ & $\begin{array}{l}-0.104 \\
(0.197)\end{array}$ & $\begin{array}{l}-0.002 \\
(0.197)\end{array}$ & $\begin{array}{l}-0.066 \\
(0.196)\end{array}$ & $\begin{array}{c}0.038 \\
(0.196)\end{array}$ & $\begin{array}{c}0.759^{\star \star \star} \\
(0.194)\end{array}$ & $\begin{array}{c}0.746^{\star \star \star} \\
(0.191)\end{array}$ & $\begin{array}{c}0.706^{\star \star \star} \\
(0.192)\end{array}$ & $\begin{array}{c}0.855^{\star \star \star} \\
(0.191)\end{array}$ & $\begin{array}{c}0.790^{\star * *} \\
(0.190)\end{array}$ & $\begin{array}{c}0.899^{\star * *} \\
(0.190)\end{array}$ \\
\hline Bank assets (\% GDP) & $\begin{array}{l}0.001^{\star *} \\
(0.001)\end{array}$ & $\begin{array}{l}0.002^{\star \star} \\
(0.001)\end{array}$ & $\begin{array}{l}0.002^{\star *} \\
(0.001)\end{array}$ & $\begin{array}{l}0.001^{*} \\
(0.001)\end{array}$ & $\begin{array}{l}0.002^{\star \star} \\
(0.001)\end{array}$ & $\begin{array}{l}0.001^{*} \\
(0.001)\end{array}$ & $\begin{array}{l}0.006^{\star \star *} \\
(0.001)\end{array}$ & $\begin{array}{c}0.006^{\star \star \star} \\
(0.001)\end{array}$ & $\begin{array}{l}0.006^{\star \star *} \\
(0.001)\end{array}$ & $\begin{array}{l}0.006^{* * *} \\
(0.001)\end{array}$ & $\begin{array}{l}0.006^{* * *} \\
(0.001)\end{array}$ & $\begin{array}{l}0.005^{\star \star *} \\
(0.001)\end{array}$ \\
\hline Institutional quality & $\begin{array}{c}0.012 \\
(0.012)\end{array}$ & $\begin{array}{c}0.012 \\
(0.012)\end{array}$ & $\begin{array}{c}0.009 \\
(0.012)\end{array}$ & $\begin{array}{c}0.013 \\
(0.012)\end{array}$ & $\begin{array}{c}0.010 \\
(0.012)\end{array}$ & $\begin{array}{c}0.016 \\
(0.012)\end{array}$ & $\begin{array}{c}0.008 \\
(0.012)\end{array}$ & $\begin{array}{c}0.008 \\
(0.012)\end{array}$ & $\begin{array}{c}0.006 \\
(0.012)\end{array}$ & $\begin{array}{c}0.010 \\
(0.012)\end{array}$ & $\begin{array}{c}0.007 \\
(0.012)\end{array}$ & $\begin{array}{c}0.013 \\
(0.012)\end{array}$ \\
\hline Capital account openness & $\begin{array}{l}0.001 \\
(0.002)\end{array}$ & $\begin{array}{c}0.002 \\
(0.002)\end{array}$ & $\begin{array}{c}0.002 \\
(0.002)\end{array}$ & $\begin{array}{l}0.001 \\
(0.002)\end{array}$ & $\begin{array}{c}0.003 \\
(0.002)\end{array}$ & $\begin{array}{l}0.001 \\
(0.002)\end{array}$ & $\begin{array}{c}0.008^{\star * *} \\
(0.002)\end{array}$ & $\begin{array}{c}0.009^{\star * *} \\
(0.002)\end{array}$ & $\begin{array}{c}0.009^{\star \star *} \\
(0.002)\end{array}$ & $\begin{array}{l}0.008^{\star \star \star} \\
(0.002)\end{array}$ & $\begin{array}{l}0.010^{\star \star \star *} \\
(0.002)\end{array}$ & $\begin{array}{l}0.009^{* * *} \\
(0.002)\end{array}$ \\
\hline Log-total other borrowing & $\begin{array}{l}0.091^{* *} \\
(0.037)\end{array}$ & $\begin{array}{c}0.118^{* \star *} \\
(0.039)\end{array}$ & $\begin{array}{l}0.105^{\star * *} \\
(0.038)\end{array}$ & $\begin{array}{l}0.106^{* * *} \\
(0.038)\end{array}$ & $\begin{array}{l}0.107^{\star \star *} \\
(0.038)\end{array}$ & $\begin{array}{l}0.093^{* *} \\
(0.038)\end{array}$ & $\begin{array}{c}0.049 \\
(0.067) \\
\end{array}$ & $\begin{array}{c}0.091 \\
(0.068)\end{array}$ & $\begin{array}{c}0.060 \\
(0.069)\end{array}$ & $\begin{array}{c}0.071 \\
(0.067) \\
\end{array}$ & $\begin{array}{c}0.072 \\
(0.067) \\
\end{array}$ & $\begin{array}{c}0.044 \\
(0.070)\end{array}$ \\
\hline$\frac{\text { Interactions with GFC }}{\text { Log-real trade }{ }^{*} \text { GFC }}$ & $\begin{array}{c}0.081^{\star \star *} \\
(0.019)\end{array}$ & & & & & $\begin{array}{c}0.075^{\star \star *} \\
(0.020)\end{array}$ & $\begin{array}{c}0.074^{\star \star *} \\
(0.019)\end{array}$ & & & & & $\begin{array}{c}0.062^{\star \star *} \\
(0.021)\end{array}$ \\
\hline Log-geographical distance*GFC & & $\begin{array}{c}-0.084^{* * *} \\
(0.030)\end{array}$ & & & & $\begin{array}{l}-0.010 \\
(0.037)\end{array}$ & & $\begin{array}{l}-0.105^{\star * *} \\
(0.031)\end{array}$ & & & & $\begin{array}{l}-0.038 \\
(0.038)\end{array}$ \\
\hline Bank capital-to-assets ratio*GFC & & & $\begin{array}{l}0.006 \\
(0.016)\end{array}$ & & & $\begin{array}{l}-0.001 \\
(0.016)\end{array}$ & & & $\begin{array}{c}0.018 \\
(0.019)\end{array}$ & & & $\begin{array}{c}0.015 \\
(0.020)\end{array}$ \\
\hline Capital account openness*GFC & & & & $\begin{array}{l}0.005^{\star \star \star} \\
(0.002)\end{array}$ & & $\begin{array}{l}0.003^{*} \\
(0.002)\end{array}$ & & & & $\begin{array}{l}0.006^{* * *} \\
(0.002)\end{array}$ & & $\begin{array}{c}0.003 \\
(0.002)\end{array}$ \\
\hline Institutional quality ${ }^{\star} \mathrm{GFC}$ & & & & & $\begin{array}{c}0.014 \\
(0.011) \\
\end{array}$ & $\begin{array}{c}0.004 \\
(0.011) \\
\end{array}$ & & & & & $\begin{array}{c}0.027^{\star \star \star} \\
(0.009)\end{array}$ & $\begin{array}{l}0.016^{\star} \\
(0.009)\end{array}$ \\
\hline Observations & 9,213 & 9,213 & 9,213 & 9,213 & 9,213 & 9,213 & 9,213 & 9,213 & 9,213 & 9,213 & 9,213 & 9,213 \\
\hline R-squared & 0.812 & 0.811 & 0.811 & 0.811 & 0.811 & 0.812 & 0.787 & 0.786 & 0.786 & 0.787 & 0.786 & 0.787 \\
\hline
\end{tabular}

Notes: The dependent variable is log-SLE (columns 1-6) and log-non-SLE (columns 7-12) vis-à-vis all borrowers. Sample period: 1995-2012. Sample comprises all country-pairs. All regressions include year and country fixed effects. The effect of the global financial crisis dummy ("GFC") is subsumed in the year fixed effects. Standard errors are clustered on country pair. See Table 2 for variable definitions and sources. 
Table 6. Alternative estimation approach - country pair effects

\begin{tabular}{|c|c|c|c|c|c|c|}
\hline \multirow[b]{4}{*}{ Within-pair } & $(1)$ & $(2)$ & (3) & (4) & $(5)$ & $(6)$ \\
\hline & \multicolumn{3}{|c|}{ Dependent variable: Log-SLE } & \multicolumn{3}{|c|}{ Dependent variable: Log-non-SLE } \\
\hline & Full & $\begin{array}{c}\mathrm{AE} \\
\text { borrowers }\end{array}$ & $\begin{array}{c}\text { EME } \\
\text { borrowers }\end{array}$ & Full & $\begin{array}{c}\mathrm{AE} \\
\text { borrowers }\end{array}$ & $\begin{array}{c}\text { EME } \\
\text { borrowers }\end{array}$ \\
\hline & & & & & & \\
\hline Log-real trade & $\begin{array}{c}0.077^{\star \star *} \\
(0.028)\end{array}$ & $\begin{array}{l}0.057^{*} \\
(0.031)\end{array}$ & $\begin{array}{l}0.135^{*} \\
(0.073)\end{array}$ & $\begin{array}{l}0.024^{*} \\
(0.014)\end{array}$ & $\begin{array}{l}-0.010 \\
(0.016)\end{array}$ & $\begin{array}{l}0.165^{\star *} \\
(0.083)\end{array}$ \\
\hline 1: Foreign affiliate & $\begin{array}{c}0.042 \\
(0.055) \\
\end{array}$ & $\begin{array}{l}-0.026 \\
(0.077) \\
\end{array}$ & $\begin{array}{c}0.024 \\
(0.087) \\
\end{array}$ & $\begin{array}{l}0.132^{* *} \\
(0.061)\end{array}$ & $\begin{array}{c}0.067 \\
(0.079) \\
\end{array}$ & $\begin{array}{c}0.125 \\
(0.098) \\
\end{array}$ \\
\hline \multicolumn{7}{|l|}{ Lender characteristics } \\
\hline Log-per capita GDP & $\begin{array}{l}-0.305 \\
(0.330)\end{array}$ & $\begin{array}{l}-0.191 \\
(0.485)\end{array}$ & $\begin{array}{l}-0.781^{*} \\
(0.443)\end{array}$ & $\begin{array}{c}0.417 \\
(0.309)\end{array}$ & $\begin{array}{c}0.395 \\
(0.370)\end{array}$ & $\begin{array}{c}0.100 \\
(0.544)\end{array}$ \\
\hline Bank assets (\% GDP) & $\begin{array}{c}0.001 \\
(0.001)\end{array}$ & $\begin{array}{c}0.001^{*} \\
(0.001)\end{array}$ & $\begin{array}{l}-0.000 \\
(0.001)\end{array}$ & $\begin{array}{c}0.001 \\
(0.001)\end{array}$ & $\begin{array}{l}-0.000 \\
(0.001)\end{array}$ & $\begin{array}{l}0.003^{\star *} \\
(0.001)\end{array}$ \\
\hline Bank capital-to-assets ratio & $\begin{array}{c}-0.066^{\star * *} \\
(0.014)\end{array}$ & $\begin{array}{c}-0.070^{* * *} \\
(0.020)\end{array}$ & $\begin{array}{c}-0.063^{\star * \star} \\
(0.022)\end{array}$ & $\begin{array}{l}-0.028^{*} \\
(0.016)\end{array}$ & $\begin{array}{l}-0.026 \\
(0.021)\end{array}$ & $\begin{array}{l}-0.029 \\
(0.023)\end{array}$ \\
\hline Log-total other lending & $\begin{array}{c}0.735^{\star * *} \\
(0.030) \\
\end{array}$ & $\begin{array}{c}0.771^{\star * *} \\
(0.058) \\
\end{array}$ & $\begin{array}{c}0.661^{* * *} \\
(0.040)\end{array}$ & $\begin{array}{c}0.297^{\star \star *} \\
(0.062) \\
\end{array}$ & $\begin{array}{c}0.084 \\
(0.068) \\
\end{array}$ & $\begin{array}{c}0.336^{\star \star \star} \\
(0.042) \\
\end{array}$ \\
\hline \multicolumn{7}{|l|}{ Borrower characteristics } \\
\hline Log-per capita GDP & $\begin{array}{c}0.041 \\
(0.171)\end{array}$ & $\begin{array}{l}-0.538 \\
(0.475)\end{array}$ & $\begin{array}{c}0.237 \\
(0.283)\end{array}$ & $\begin{array}{c}0.680^{* * *} \\
(0.197)\end{array}$ & $\begin{array}{l}1.222^{* *} \\
(0.498)\end{array}$ & $\begin{array}{l}0.527^{*} \\
(0.308)\end{array}$ \\
\hline Bank assets (\% GDP) & $\begin{array}{c}0.001 \\
(0.001)\end{array}$ & $\begin{array}{l}-0.000 \\
(0.001)\end{array}$ & $\begin{array}{c}0.002 \\
(0.002)\end{array}$ & $\begin{array}{c}0.004^{\star \star *} \\
(0.001)\end{array}$ & $\begin{array}{c}0.002^{\star * \star} \\
(0.001)\end{array}$ & $\begin{array}{c}0.007^{\star \star \star} \\
(0.002)\end{array}$ \\
\hline Institutional quality & $\begin{array}{c}0.005 \\
(0.010)\end{array}$ & $\begin{array}{c}0.019 \\
(0.066)\end{array}$ & $\begin{array}{c}0.016 \\
(0.010)\end{array}$ & $\begin{array}{c}0.004 \\
(0.011)\end{array}$ & $\begin{array}{c}0.016 \\
(0.070)\end{array}$ & $\begin{array}{c}0.008 \\
(0.012)\end{array}$ \\
\hline Capital account openness & $\begin{array}{c}0.001 \\
(0.002)\end{array}$ & $\begin{array}{c}0.002 \\
(0.005)\end{array}$ & $\begin{array}{c}0.001 \\
(0.002)\end{array}$ & $\begin{array}{c}0.008^{\star \star \star} \\
(0.002)\end{array}$ & $\begin{array}{l}-0.005 \\
(0.005)\end{array}$ & $\begin{array}{l}0.009^{\star \star \star} \\
(0.002)\end{array}$ \\
\hline Log-total other borrowing & $\begin{array}{l}0.200^{\star \star \star *} \\
(0.038)\end{array}$ & $\begin{array}{c}0.286^{\star * *} \\
(0.059)\end{array}$ & $\begin{array}{l}0.122^{\star \star \star} \\
(0.044)\end{array}$ & $\begin{array}{c}0.365^{\star \star \star} \\
(0.056)\end{array}$ & $\begin{array}{c}0.479^{* * *} \\
(0.078)\end{array}$ & $\begin{array}{l}0.259^{\star \star \star} \\
(0.087)\end{array}$ \\
\hline Observations & 9,213 & 4,601 & 4,200 & 9,213 & 4,601 & 4,200 \\
\hline R-squared & 0.938 & 0.942 & 0.915 & 0.919 & 0.917 & 0.866 \\
\hline
\end{tabular}

Notes: The dependent variable is log-SLE (columns 1-3) and log-non-SLE (columns 4-6). Sample period: 1995-2012. All regressions include year and country-pair fixed effects. Standard errors are clustered on country pair. See Table 2 for variable definitions and sources. 
Table 7. Alternative specifications - Additional lender country characteristics

\begin{tabular}{|c|c|c|c|c|c|c|c|c|c|c|c|c|}
\hline & (1) & $(2)$ & (3) & (4) & (5) & (6) & (7) & $(8)$ & (9) & (10) & $(11)$ & (12) \\
\hline & \multicolumn{6}{|c|}{ Dependent variable: Log-SLE } & \multicolumn{6}{|c|}{ Dependent variable: Log-non-SLE } \\
\hline & Full & Full & Full & Full & Full & Full & Full & Full & Full & Full & Full & Full \\
\hline Within-pair & & & & & & & & & & & & \\
\hline Log-real trade & $\begin{array}{c}0.3142^{\star \star \star} \\
(0.036)\end{array}$ & $\begin{array}{c}0.3147^{\star \star *} \\
(0.036)\end{array}$ & $\begin{array}{c}0.3144^{\star \star *} \\
(0.036)\end{array}$ & $\begin{array}{c}0.3163^{\star \star \star} \\
(0.036)\end{array}$ & $\begin{array}{c}0.3678^{\star \star \star} \\
(0.045)\end{array}$ & $\begin{array}{c}0.3670^{\star * *} \\
(0.045)\end{array}$ & $\begin{array}{c}0.3852^{\star \star \star} \\
(0.047)\end{array}$ & $\begin{array}{c}0.3849^{* * *} \\
(0.047)\end{array}$ & $\begin{array}{c}0.3846^{\star \star *} \\
(0.047)\end{array}$ & $\begin{array}{c}0.3867^{* \star *} \\
(0.047)\end{array}$ & $\begin{array}{c}0.4952^{* * *} \\
(0.057)\end{array}$ & $\begin{array}{c}0.4950^{\star * *} \\
(0.057)\end{array}$ \\
\hline 1: Common language & $\begin{array}{c}0.2616^{\star \star *} \\
(0.099)\end{array}$ & $\begin{array}{c}0.2601^{* * *} \\
(0.099)\end{array}$ & $\begin{array}{c}0.2611^{* * *} \\
(0.099)\end{array}$ & $\begin{array}{c}0.2609^{* * *} \\
(0.099)\end{array}$ & $\begin{array}{c}0.2806^{\star * *} \\
(0.103)\end{array}$ & $\begin{array}{c}0.2795^{\star * *} \\
(0.103)\end{array}$ & $\begin{array}{l}0.1115 \\
(0.110)\end{array}$ & $\begin{array}{l}0.1113 \\
(0.110)\end{array}$ & $\begin{array}{l}0.1114 \\
(0.110)\end{array}$ & $\begin{array}{l}0.1191 \\
(0.110)\end{array}$ & $\begin{array}{l}0.0643 \\
(0.115)\end{array}$ & $\begin{array}{l}0.0633 \\
(0.115)\end{array}$ \\
\hline Log-geographical distance & $\begin{array}{c}-0.3460^{* * *} \\
(0.061)\end{array}$ & $\begin{array}{c}-0.3455^{\star * *} \\
(0.061)\end{array}$ & $\begin{array}{c}-0.3450^{* * *} \\
(0.061)\end{array}$ & $\begin{array}{c}-0.3435^{\star * *} \\
(0.061)\end{array}$ & $\begin{array}{c}-0.3022^{* * *} \\
(0.067)\end{array}$ & $\begin{array}{c}-0.3032^{* \star *} \\
(0.067)\end{array}$ & $\begin{array}{c}-0.6524^{* * *} \\
(0.070)\end{array}$ & $\begin{array}{c}-0.6525^{\star * *} \\
(0.070)\end{array}$ & $\begin{array}{c}-0.6525^{\star * *} \\
(0.070)\end{array}$ & $\begin{array}{c}-0.6467^{* * *} \\
(0.069)\end{array}$ & $\begin{array}{c}-0.5385^{\star * *} \\
(0.076)\end{array}$ & $\begin{array}{c}-0.5384^{* * *} \\
(0.076)\end{array}$ \\
\hline 1: Foreign affiliate & $\begin{array}{c}0.5253^{\star * *} \\
(0.062)\end{array}$ & $\begin{array}{c}0.5263^{\star * *} \\
(0.062)\end{array}$ & $\begin{array}{c}0.5306^{\star \star *} \\
(0.062)\end{array}$ & $\begin{array}{c}0.5243^{* * *} \\
(0.062)\end{array}$ & $\begin{array}{c}0.5337^{\star * *} \\
(0.068)\end{array}$ & $\begin{array}{c}0.5343^{\star * *} \\
(0.068)\end{array}$ & $\begin{array}{c}0.7681^{\star * *} \\
(0.068)\end{array}$ & $\begin{array}{c}0.7666^{* \star *} \\
(0.067)\end{array}$ & $\begin{array}{c}0.7704^{* * *} \\
(0.068)\end{array}$ & $\begin{array}{c}0.7649^{* * *} \\
(0.067)\end{array}$ & $\begin{array}{c}0.8240^{* * *} \\
(0.073)\end{array}$ & $\begin{array}{c}0.8258^{* * *} \\
(0.074)\end{array}$ \\
\hline Lender characteristics & & & & & & & & & & & & \\
\hline Log-per capita GDP & $\begin{array}{l}-0.4881 \\
(0.353)\end{array}$ & $\begin{array}{l}-0.5405 \\
(0.357)\end{array}$ & $\begin{array}{l}-0.5259 \\
(0.353)\end{array}$ & $\begin{array}{l}-0.4999 \\
(0.363)\end{array}$ & $\begin{array}{l}-0.3453 \\
(0.379)\end{array}$ & $\begin{array}{l}-0.5726 \\
(0.392)\end{array}$ & $\begin{array}{l}-0.2276 \\
(0.345)\end{array}$ & $\begin{array}{l}-0.2747 \\
(0.353)\end{array}$ & $\begin{array}{l}-0.2764 \\
(0.347)\end{array}$ & $\begin{array}{l}-0.2403 \\
(0.354)\end{array}$ & $\begin{array}{l}-0.3672 \\
(0.379)\end{array}$ & $\begin{array}{l}-0.5098 \\
(0.401)\end{array}$ \\
\hline Bank assets (\% GDP) & $\begin{array}{l}-0.0000 \\
(0.001)\end{array}$ & $\begin{array}{l}0.0000 \\
(0.001)\end{array}$ & $\begin{array}{l}0.0000 \\
(0.001)\end{array}$ & $\begin{array}{l}0.0002 \\
(0.001)\end{array}$ & $\begin{array}{l}0.0003 \\
(0.001)\end{array}$ & $\begin{array}{l}0.0006 \\
(0.001)\end{array}$ & $\begin{array}{l}-0.0003 \\
(0.001)\end{array}$ & $\begin{array}{l}-0.0002 \\
(0.001)\end{array}$ & $\begin{array}{l}-0.0002 \\
(0.001)\end{array}$ & $\begin{array}{l}-0.0003 \\
(0.001)\end{array}$ & $\begin{array}{l}-0.0004 \\
(0.001)\end{array}$ & $\begin{array}{l}-0.0001 \\
(0.001)\end{array}$ \\
\hline Bank capital-to-assets ratio & $\begin{array}{c}-0.0416^{\star \star \star} \\
(0.015)\end{array}$ & $\begin{array}{c}-0.0367^{\star \star} \\
(0.015)\end{array}$ & $\begin{array}{c}-0.0391^{\star \star} \\
(0.015)\end{array}$ & $\begin{array}{c}-0.0365^{\star \star} \\
(0.016)\end{array}$ & $\begin{array}{l}-0.0214 \\
(0.017)\end{array}$ & $\begin{array}{l}-0.0243 \\
(0.017)\end{array}$ & $\begin{array}{l}-0.0146 \\
(0.017)\end{array}$ & $\begin{array}{l}-0.0122 \\
(0.018)\end{array}$ & $\begin{array}{l}-0.0129 \\
(0.017)\end{array}$ & $\begin{array}{c}-0.0159 \\
(0.017)\end{array}$ & $\begin{array}{l}-0.0005 \\
(0.018)\end{array}$ & $\begin{array}{l}0.0000 \\
(0.019)\end{array}$ \\
\hline Log-total other lending & $\begin{array}{c}0.6144^{\star \star *} \\
(0.031)\end{array}$ & $\begin{array}{c}0.6137^{\star * *} \\
(0.031)\end{array}$ & $\begin{array}{c}0.6138^{* * *} \\
(0.031)\end{array}$ & $\begin{array}{c}0.6099^{* * *} \\
(0.031)\end{array}$ & $\begin{array}{c}0.6006^{\star * *} \\
(0.032)\end{array}$ & $\begin{array}{c}0.6009^{* * *} \\
(0.032)\end{array}$ & $\begin{array}{l}0.0245 \\
(0.039)\end{array}$ & $\begin{array}{l}0.0246 \\
(0.039)\end{array}$ & $\begin{array}{l}0.0243 \\
(0.039)\end{array}$ & $\begin{array}{l}0.0195 \\
(0.039)\end{array}$ & $\begin{array}{l}0.0072 \\
(0.039)\end{array}$ & $\begin{array}{l}0.0071 \\
(0.039)\end{array}$ \\
\hline Net interest margin & $\begin{array}{l}-0.0477 \\
(0.050)\end{array}$ & & & & & $\begin{array}{c}-0.0673 \\
(0.057)\end{array}$ & $\begin{array}{l}0.0224 \\
(0.048)\end{array}$ & & & & & $\begin{array}{l}0.0218 \\
(0.053)\end{array}$ \\
\hline Liquid assets & & $\begin{array}{l}0.0025 \\
(0.002)\end{array}$ & & & & $\begin{array}{l}-0.0007 \\
(0.002)\end{array}$ & & $\begin{array}{l}0.0017 \\
(0.002)\end{array}$ & & & & $\begin{array}{l}0.0004 \\
(0.003)\end{array}$ \\
\hline Return on assets & & & $\begin{array}{l}0.0528 \\
(0.034)\end{array}$ & & & $\begin{array}{l}0.0589 \\
(0.038)\end{array}$ & & & $\begin{array}{l}0.0542 \\
(0.039)\end{array}$ & & & $\begin{array}{l}0.0152 \\
(0.043)\end{array}$ \\
\hline Loan loss reserves (\% gross loans) & & & & $\begin{array}{l}-0.0069 \\
(0.017)\end{array}$ & & $\begin{array}{l}-0.0329 \\
(0.022)\end{array}$ & & & & $\begin{array}{l}-0.0028 \\
(0.019)\end{array}$ & & $\begin{array}{l}-0.0280 \\
(0.024)\end{array}$ \\
\hline Net charge-offs (\% gross loans) & & & & & $\begin{array}{c}0.0603^{\star *} \\
(0.030)\end{array}$ & $\begin{array}{c}0.0724^{\star *} \\
(0.031)\end{array}$ & & & & & $\begin{array}{l}0.0453 \\
(0.036)\end{array}$ & $\begin{array}{l}0.0489 \\
(0.037)\end{array}$ \\
\hline Borrower characteristics & & & & & & & & & & & & \\
\hline Log-per capita GDP & $\begin{array}{l}-0.1302 \\
(0.224)\end{array}$ & $\begin{array}{l}-0.1397 \\
(0.224)\end{array}$ & $\begin{array}{l}-0.1380 \\
(0.224)\end{array}$ & $\begin{array}{l}-0.1440 \\
(0.226)\end{array}$ & $\begin{array}{l}-0.0582 \\
(0.272)\end{array}$ & $\begin{array}{l}-0.0559 \\
(0.273)\end{array}$ & $\begin{array}{c}0.7560^{\star \star \star} \\
(0.211)\end{array}$ & $\begin{array}{c}0.7555^{\star \star \star} \\
(0.211)\end{array}$ & $\begin{array}{c}0.7566^{\star \star \star} \\
(0.211)\end{array}$ & $\begin{array}{c}0.7662^{\star \star \star} \\
(0.213)\end{array}$ & $\begin{array}{c}0.6918^{\star \star \star} \\
(0.253)\end{array}$ & $\begin{array}{c}0.6850^{\star * *} \\
(0.254)\end{array}$ \\
\hline Bank assets (\% GDP) & $\begin{array}{c}0.0014^{\star *} \\
(0.001)\end{array}$ & $\begin{array}{c}0.0014^{* *} \\
(0.001)\end{array}$ & $\begin{array}{c}0.0015^{\star *} \\
(0.001)\end{array}$ & $\begin{array}{l}0.0013^{*} \\
(0.001)\end{array}$ & $\begin{array}{l}0.0008 \\
(0.001)\end{array}$ & $\begin{array}{l}0.0008 \\
(0.001)\end{array}$ & $\begin{array}{c}0.0057^{\star * *} \\
(0.001)\end{array}$ & $\begin{array}{c}0.0057^{\star * *} \\
(0.001)\end{array}$ & $\begin{array}{c}0.0057^{\star * *} \\
(0.001)\end{array}$ & $\begin{array}{c}0.0054^{\star * *} \\
(0.001)\end{array}$ & $\begin{array}{c}0.0049^{* * *} \\
(0.001)\end{array}$ & $\begin{array}{c}0.0049^{* * *} \\
(0.001)\end{array}$ \\
\hline Institutional quality & $\begin{array}{l}0.0072 \\
(0.014)\end{array}$ & $\begin{array}{l}0.0068 \\
(0.014)\end{array}$ & $\begin{array}{l}0.0070 \\
(0.014)\end{array}$ & $\begin{array}{l}0.0066 \\
(0.014)\end{array}$ & $\begin{array}{l}0.0109 \\
(0.018)\end{array}$ & $\begin{array}{l}0.0102 \\
(0.017)\end{array}$ & $\begin{array}{l}0.0048 \\
(0.013)\end{array}$ & $\begin{array}{l}0.0046 \\
(0.013)\end{array}$ & $\begin{array}{l}0.0045 \\
(0.013)\end{array}$ & $\begin{array}{l}0.0076 \\
(0.014)\end{array}$ & $\begin{array}{l}0.0131 \\
(0.015)\end{array}$ & $\begin{array}{l}0.0126 \\
(0.015)\end{array}$ \\
\hline Capital account openness & $\begin{array}{l}0.0014 \\
(0.002)\end{array}$ & $\begin{array}{l}0.0013 \\
(0.002)\end{array}$ & $\begin{array}{l}0.0013 \\
(0.002)\end{array}$ & $\begin{array}{l}0.0016 \\
(0.002)\end{array}$ & $\begin{array}{l}0.0020 \\
(0.002)\end{array}$ & $\begin{array}{l}0.0020 \\
(0.002)\end{array}$ & $\begin{array}{c}0.0089^{* * *} \\
(0.002)\end{array}$ & $\begin{array}{c}0.0090^{* * *} \\
(0.002)\end{array}$ & $\begin{array}{c}0.0090^{\star \star \star} \\
(0.002)\end{array}$ & $\begin{array}{c}0.0087^{\star \star \star} \\
(0.002)\end{array}$ & $\begin{array}{c}0.0083^{\star \star \star} \\
(0.003)\end{array}$ & $\begin{array}{c}0.0082^{\star \star *} \\
(0.003)\end{array}$ \\
\hline Log-total other borrowing & $\begin{array}{c}0.0772^{\star *} \\
(0.039)\end{array}$ & $\begin{array}{c}0.0797^{\star \star} \\
(0.040)\end{array}$ & $\begin{array}{c}0.0805^{\star \star} \\
(0.039)\end{array}$ & $\begin{array}{c}0.0817^{\star \star} \\
(0.040)\end{array}$ & $\begin{array}{l}0.0671 \\
(0.041)\end{array}$ & $\begin{array}{l}0.0635 \\
(0.041)\end{array}$ & $\begin{array}{l}-0.0137 \\
(0.072) \\
\end{array}$ & $\begin{array}{l}-0.0320 \\
(0.078) \\
\end{array}$ & $\begin{array}{l}-0.0153 \\
(0.072)\end{array}$ & $\begin{array}{r}0.0049 \\
(0.070) \\
\end{array}$ & $\begin{array}{l}-0.0457 \\
(0.081) \\
\end{array}$ & $\begin{array}{c}-0.0494 \\
(0.083)\end{array}$ \\
\hline Observations & 8,464 & 8,464 & 8,464 & 8,363 & 7,185 & 7,185 & 8,464 & 8,464 & 8,464 & 8,363 & 7,185 & 7,185 \\
\hline R-squared & 0.816 & 0.816 & 0.816 & 0.817 & 0.820 & 0.820 & 0.790 & 0.790 & 0.790 & 0.793 & 0.791 & 0.791 \\
\hline
\end{tabular}

Notes: The dependent variable is log-SLE (columns 1-6) and log-non-SLE (columns 7-12). Sample period: 1995-2012. All regressions include year and country fixed effects. Standard errors are clustered on country pair. See Table 2 for variable definitions and sources. 
Table 8. Alternative specifications - Additional borrower country characteristics

\begin{tabular}{|c|c|c|c|c|c|c|c|c|c|c|c|c|}
\hline & (1) & (2) & (3) & (4) & (5) & (6) & (7) & (8) & (9) & (10) & (11) & (12) \\
\hline & \multicolumn{6}{|c|}{ Dependent variable: Log-SLE } & \multicolumn{6}{|c|}{ Dependent variable: Log-non-SLE } \\
\hline & Full & Full & Full & Full & Full & Full & Full & Full & Full & Full & Full & Full \\
\hline Within-pair & & & & & & & & & & & & \\
\hline Log-real trade & $\begin{array}{c}0.3475^{* * *} \\
(0.046)\end{array}$ & $\begin{array}{c}0.2327^{* * *} \\
(0.030)\end{array}$ & $\begin{array}{c}0.3085^{\star * *} \\
(0.096)\end{array}$ & $\begin{array}{c}0.2393^{* * *} \\
(0.029)\end{array}$ & $\begin{array}{c}0.2359^{* * *} \\
(0.029)\end{array}$ & $\begin{array}{c}0.3910^{* * *} \\
(0.092)\end{array}$ & $\begin{array}{c}0.4928^{* * *} \\
(0.055)\end{array}$ & $\begin{array}{c}0.2461^{* * *} \\
(0.038)\end{array}$ & $\begin{array}{c}0.3658^{* * *} \\
(0.082)\end{array}$ & $\begin{array}{c}0.2494^{* * *} \\
(0.039)\end{array}$ & $\begin{array}{c}0.2413^{* * *} \\
(0.038)\end{array}$ & $\begin{array}{c}0.4170^{\star * *} \\
(0.096)\end{array}$ \\
\hline 1: Common language & $\begin{array}{c}0.4608^{* * *} \\
(0.123)\end{array}$ & $\begin{array}{c}0.2720^{* * *} \\
(0.101)\end{array}$ & $\begin{array}{c}0.4300^{* *} \\
(0.191)\end{array}$ & $\begin{array}{c}0.2820^{* * *} \\
(0.099)\end{array}$ & $\begin{array}{c}0.2782^{* * *} \\
(0.101)\end{array}$ & $\begin{array}{l}0.2986 \\
(0.190)\end{array}$ & $\begin{array}{l}0.2405^{\star} \\
(0.131)\end{array}$ & $\begin{array}{l}0.1599 \\
(0.111)\end{array}$ & $\begin{array}{c}0.5174^{* * *} \\
(0.167)\end{array}$ & $\begin{array}{l}0.1563 \\
(0.110)\end{array}$ & $\begin{array}{l}0.0949 \\
(0.112)\end{array}$ & $\begin{array}{c}0.4258^{\star *} \\
(0.180)\end{array}$ \\
\hline Log-geographical distance & $\begin{array}{c}-0.3162^{* * *} \\
(0.076)\end{array}$ & $\begin{array}{c}-0.4234^{* * *} \\
(0.056)\end{array}$ & $\begin{array}{c}-0.5095^{\star * *} \\
(0.160)\end{array}$ & $\begin{array}{c}-0.4255^{\star * *} \\
(0.056)\end{array}$ & $\begin{array}{c}-0.4202^{* * *} \\
(0.059)\end{array}$ & $\begin{array}{c}-0.4872^{* * *} \\
(0.150)\end{array}$ & $\begin{array}{c}-0.5973^{* * *} \\
(0.089)\end{array}$ & $\begin{array}{c}-0.7918^{* * *} \\
(0.065)\end{array}$ & $\begin{array}{c}-0.8530^{* * *} \\
(0.138)\end{array}$ & $\begin{array}{c}-0.7836^{* * *} \\
(0.065)\end{array}$ & $\begin{array}{c}-0.7989^{* * *} \\
(0.067)\end{array}$ & $\begin{array}{c}-0.8659^{* * *} \\
(0.156)\end{array}$ \\
\hline 1: Foreign affiliate & $\begin{array}{c}0.4957^{\star \star \star} \\
(0.069)\end{array}$ & $\begin{array}{c}0.5237^{\star \star \star} \\
(0.062)\end{array}$ & $\begin{array}{c}0.4125^{\star \star \star} \\
(0.110)\end{array}$ & $\begin{array}{c}0.5007^{\star \star \star} \\
(0.061)\end{array}$ & $\begin{array}{c}0.5080^{\star \star \star} \\
(0.064)\end{array}$ & $\begin{array}{c}0.4573^{\star * *} \\
(0.114)\end{array}$ & $\begin{array}{c}0.6416^{\star \star \star} \\
(0.071)\end{array}$ & $\begin{array}{c}0.7226^{\star * \star} \\
(0.069)\end{array}$ & $\begin{array}{c}0.5549^{\star * *} \\
(0.102)\end{array}$ & $\begin{array}{c}0.7651^{\star * *} \\
(0.069)\end{array}$ & $\begin{array}{c}0.7771^{\star \star \star} \\
(0.073)\end{array}$ & $\begin{array}{c}0.6077^{\star \star *} \\
(0.113)\end{array}$ \\
\hline Lender characteristics & & & & & & & & & & & & \\
\hline Log-per capita GDP & $\begin{array}{c}-0.9297^{\star *} \\
(0.393)\end{array}$ & $\begin{array}{l}-0.4657 \\
(0.325)\end{array}$ & $\begin{array}{l}0.0212 \\
(0.519)\end{array}$ & $\begin{array}{l}-0.3190 \\
(0.329)\end{array}$ & $\begin{array}{l}-0.3604 \\
(0.365)\end{array}$ & $\begin{array}{l}0.7289 \\
(0.630)\end{array}$ & $\begin{array}{l}-0.5519 \\
(0.390)\end{array}$ & $\begin{array}{l}0.0746 \\
(0.330)\end{array}$ & $\begin{array}{l}-0.5036 \\
(0.627)\end{array}$ & $\begin{array}{l}0.0911 \\
(0.331)\end{array}$ & $\begin{array}{l}0.0657 \\
(0.364)\end{array}$ & $\begin{array}{l}-1.1005 \\
(0.703)\end{array}$ \\
\hline Bank assets (\% GDP) & $\begin{array}{l}-0.0004 \\
(0.001)\end{array}$ & $\begin{array}{l}-0.0002 \\
(0.001)\end{array}$ & $\begin{array}{l}-0.0001 \\
(0.001)\end{array}$ & $\begin{array}{l}-0.0002 \\
(0.001)\end{array}$ & $\begin{array}{l}-0.0004 \\
(0.001)\end{array}$ & $\begin{array}{l}-0.0010 \\
(0.002)\end{array}$ & $\begin{array}{l}0.0007 \\
(0.001)\end{array}$ & $\begin{array}{l}0.0001 \\
(0.001)\end{array}$ & $\begin{array}{l}0.0028^{\star} \\
(0.002)\end{array}$ & $\begin{array}{l}-0.0001 \\
(0.001)\end{array}$ & $\begin{array}{l}0.0000 \\
(0.001)\end{array}$ & $\begin{array}{l}0.0023 \\
(0.002)\end{array}$ \\
\hline Bank capital-to-assets ratio & $\begin{array}{c}-0.0513^{\star * *} \\
(0.018)\end{array}$ & $\begin{array}{c}-0.0512^{* * *} \\
(0.016)\end{array}$ & $\begin{array}{c}-0.1001^{* * *} \\
(0.023)\end{array}$ & $\begin{array}{c}-0.0533^{* * *} \\
(0.015)\end{array}$ & $\begin{array}{c}-0.0517^{* * *} \\
(0.016)\end{array}$ & $\begin{array}{c}-0.1332^{* * *} \\
(0.027)\end{array}$ & $\begin{array}{l}-0.0139 \\
(0.021)\end{array}$ & $\begin{array}{l}-0.0144 \\
(0.018)\end{array}$ & $\begin{array}{l}-0.0305 \\
(0.029)\end{array}$ & $\begin{array}{l}-0.0074 \\
(0.018)\end{array}$ & $\begin{array}{l}0.0026 \\
(0.021)\end{array}$ & $\begin{array}{c}-0.0292 \\
(0.031)\end{array}$ \\
\hline Log-total other lending & $\begin{array}{c}0.5781^{\star * *} \\
(0.033)\end{array}$ & $\begin{array}{c}0.6348^{* * *} \\
(0.031)\end{array}$ & $\begin{array}{c}0.5816^{\star * *} \\
(0.061)\end{array}$ & $\begin{array}{c}0.6354^{\star * *} \\
(0.031)\end{array}$ & $\begin{array}{c}0.6299^{* * *} \\
(0.036)\end{array}$ & $\begin{array}{c}0.5340^{* * *} \\
(0.062)\end{array}$ & $\begin{array}{l}0.0584 \\
(0.044)\end{array}$ & $\begin{array}{l}0.0568 \\
(0.045)\end{array}$ & $\begin{array}{l}-0.0231 \\
(0.055)\end{array}$ & $\begin{array}{l}0.0416 \\
(0.044)\end{array}$ & $\begin{array}{l}-0.0406 \\
(0.044)\end{array}$ & $\begin{array}{c}-0.0820^{\star *} \\
(0.034)\end{array}$ \\
\hline Borrower characteristics & & & & & & & & & & & & \\
\hline Log-per capita GDP & $\begin{array}{l}0.0478 \\
(0.221)\end{array}$ & $\begin{array}{l}-0.1159 \\
(0.216)\end{array}$ & $\begin{array}{l}-0.1937 \\
(0.305)\end{array}$ & $\begin{array}{l}-0.1848 \\
(0.220)\end{array}$ & $\begin{array}{c}-0.3693^{\star} \\
(0.196)\end{array}$ & $\begin{array}{l}-0.5557 \\
(0.348)\end{array}$ & $\begin{array}{c}0.6591^{\star * *} \\
(0.212)\end{array}$ & $\begin{array}{c}0.7072^{\star * *} \\
(0.209)\end{array}$ & $\begin{array}{c}0.2657 \\
(0.291)\end{array}$ & $\begin{array}{c}0.7906^{\star * *} \\
(0.247)\end{array}$ & $\begin{array}{c}0.7697^{\star \star *} \\
(0.227)\end{array}$ & $\begin{array}{c}0.8854^{\star *} \\
(0.343)\end{array}$ \\
\hline Bank assets (\% GDP) & $\begin{array}{l}0.0013 \\
(0.001)\end{array}$ & $\begin{array}{c}0.0017^{\star \star} \\
(0.001)\end{array}$ & $\begin{array}{l}0.0030 \\
(0.003)\end{array}$ & $\begin{array}{c}0.0017^{\star \star} \\
(0.001)\end{array}$ & $\begin{array}{l}0.0010 \\
(0.001)\end{array}$ & $\begin{array}{l}0.0018 \\
(0.003)\end{array}$ & $\begin{array}{c}0.0053^{\star \star \star} \\
(0.001)\end{array}$ & $\begin{array}{c}0.0057^{\star \star *} \\
(0.001)\end{array}$ & $\begin{array}{c}0.0128^{\star \star *} \\
(0.003)\end{array}$ & $\begin{array}{c}0.0057^{\star \star \star} \\
(0.001)\end{array}$ & $\begin{array}{c}0.0068^{\star \star *} \\
(0.001)\end{array}$ & $\begin{array}{c}0.0130^{\star \star *} \\
(0.003)\end{array}$ \\
\hline Institutional quality & $\begin{array}{l}0.0112 \\
(0.014)\end{array}$ & $\begin{array}{l}0.0089 \\
(0.012)\end{array}$ & $\begin{array}{l}0.0180 \\
(0.011)\end{array}$ & $\begin{array}{l}0.0194^{\star} \\
(0.011)\end{array}$ & $\begin{array}{l}0.0172 \\
(0.011)\end{array}$ & $\begin{array}{l}0.0187 \\
(0.012)\end{array}$ & $\begin{array}{c}-0.0054 \\
(0.013)\end{array}$ & $\begin{array}{l}0.0058 \\
(0.012)\end{array}$ & $\begin{array}{l}0.0124 \\
(0.013)\end{array}$ & $\begin{array}{l}0.0106 \\
(0.013)\end{array}$ & $\begin{array}{l}0.0125 \\
(0.013)\end{array}$ & $\begin{array}{l}0.0221^{*} \\
(0.013)\end{array}$ \\
\hline Capital account openness & $\begin{array}{l}0.0020 \\
(0.002)\end{array}$ & $\begin{array}{l}0.0016 \\
(0.002)\end{array}$ & $\begin{array}{l}0.0011 \\
(0.002)\end{array}$ & $\begin{array}{l}0.0033^{*} \\
(0.002)\end{array}$ & $\begin{array}{l}0.0028 \\
(0.002)\end{array}$ & $\begin{array}{l}0.0042^{*} \\
(0.002)\end{array}$ & $\begin{array}{c}0.0087^{\star \star \star} \\
(0.002)\end{array}$ & $\begin{array}{c}0.0093^{\star * \star} \\
(0.002)\end{array}$ & $\begin{array}{c}0.0118^{\star \star *} \\
(0.002)\end{array}$ & $\begin{array}{c}0.0100^{\star \star *} \\
(0.002)\end{array}$ & $\begin{array}{c}0.0095^{\star \star *} \\
(0.002)\end{array}$ & $\begin{array}{c}0.0104^{\star \star *} \\
(0.003)\end{array}$ \\
\hline Log-total other borrowing & $\begin{array}{c}0.1363^{\star \star \star} \\
(0.046)\end{array}$ & $\begin{array}{c}0.1147^{\star \star \star} \\
(0.038)\end{array}$ & $\begin{array}{l}0.0659 \\
(0.059)\end{array}$ & $\begin{array}{c}0.1233^{\star \star \star} \\
(0.039)\end{array}$ & $\begin{array}{c}0.1346^{\star \star \star} \\
(0.043)\end{array}$ & $\begin{array}{c}0.1567^{\star \star} \\
(0.068)\end{array}$ & $\begin{array}{l}0.0614 \\
(0.074)\end{array}$ & $\begin{array}{l}0.0830 \\
(0.067)\end{array}$ & $\begin{array}{l}0.1049 \\
(0.096)\end{array}$ & $\begin{array}{l}0.0779 \\
(0.069)\end{array}$ & $\begin{array}{c}0.0298 \\
(0.074)\end{array}$ & $\begin{array}{c}-0.0378 \\
(0.106)\end{array}$ \\
\hline Exchange rate volatility (lagged) & $\begin{array}{l}-0.0000 \\
(0.000)\end{array}$ & & & & & $\begin{array}{l}-0.0000 \\
(0.000)\end{array}$ & $\begin{array}{l}0.0001 \\
(0.000)\end{array}$ & & & & & $\begin{array}{l}-0.0001 \\
(0.000)\end{array}$ \\
\hline Stock market capitalization (\% GDP) & & $\begin{array}{l}0.0005 \\
(0.001)\end{array}$ & & & & $\begin{array}{l}0.0009 \\
(0.001)\end{array}$ & & $\begin{array}{l}-0.0012 \\
(0.001)\end{array}$ & & & & $\begin{array}{l}-0.0013 \\
(0.002)\end{array}$ \\
\hline Stock market return volatility & & & $\begin{array}{c}-0.0002^{\star \star \star} \\
(0.000)\end{array}$ & & & $\begin{array}{c}-0.0002^{* *} \\
(0.000)\end{array}$ & & & $\begin{array}{c}-0.0002^{\star *} \\
(0.000)\end{array}$ & & & $\begin{array}{c}-0.0002^{\star *} \\
(0.000)\end{array}$ \\
\hline S\&P Sovereign credit rating & & & & $\begin{array}{l}0.0043 \\
(0.004)\end{array}$ & & $\begin{array}{c}0.0032 \\
(0.006)\end{array}$ & & & & $\begin{array}{l}0.0056 \\
(0.005)\end{array}$ & & $\begin{array}{l}-0.0042 \\
(0.008)\end{array}$ \\
\hline$\%$ internationally rated banks & & & & & $\begin{array}{l}0.0008 \\
(0.001)\end{array}$ & $\begin{array}{l}-0.0008 \\
(0.002)\end{array}$ & & & & & $\begin{array}{c}0.0033^{\star \star \star} \\
(0.001)\end{array}$ & $\begin{array}{c}0.0036^{\star *} \\
(0.002)\end{array}$ \\
\hline Observations & 6,654 & 9,000 & 3,042 & 8,801 & 7,549 & 2,150 & 6,654 & 9,000 & 3,042 & 8,801 & 7,549 & 2,150 \\
\hline R-squared & 0.801 & 0.812 & 0.750 & 0.816 & 0.819 & 0.775 & 0.778 & 0.782 & 0.716 & 0.787 & 0.790 & 0.727 \\
\hline
\end{tabular}

Notes: The dependent variable is log-SLE (columns 1-6) and log-non-SLE (columns 7-12). Sample period: 1995-2012. All regressions include year and country fixed effects. Standard errors are clustered on country pair. See Table 2 for variable definitions and sources. 


\section{APPENDIX (not for publication)}

\section{DAta SOURCES AND DESCRIPTION}

\section{A. Syndicated loans}

The syndicated loan data come from Dealogic's Loan Analytics. We downloaded data for 153,255 syndicated loan deals signed during the 1990-2012 period to compute cross-border exposures for 19952012. For each loan, the database offers detailed information on contractual characteristics including lender and borrower identity, loan type (credit line, term loan), size, maturity, interest rate, and currency.

Information on whether syndicated loans are credit lines (CL) or upfront term loans (TL) is available at the tranche level in the variable "tranche instrument type." When multiple classifications are available, we prioritize the first one in classifying the loan as CL or TL. Deals with tranches labeled as "multiple facility" are classified as CLs because they include revolvers and may not be fully drawn. Other facilities classified as CLs include Bridge Facility, Credit Facility, L/C Facility, Reducing Revolving Credit, and Revolving Credit. The main types of facilities classified as TL include "Term Loans" (A, B, $\mathrm{C}$, D, etc.). When in doubt, we were conservative and classified more of the tranches as CLs. For further details on how we processed syndicated loan data, see the appendix of Hale, Kapan and Minoiu (2014).

A major challenge in our analysis is to ensure that the way in which we split loan deal amounts across lenders-that is, by pro-rating them-does not generate systematic biases in estimated country-pair loan volumes (and hence exposures), and does not underperform relative to alternative data imputation methods.

We check the performance of our method with the following exercise. We limit the sample to loans issued during 2006-2010, for which we have individual loans shares, and compare the loan issuance volume in-sample with that obtained from three imputation methods: (i) splitting loan amounts equally across syndicate members ("pro-rata"); (ii) predicting the shares using a regression model of log-shares against a large number of loan characteristics ("regression") as in de Haas and van Horen (2013) and Kapan and Minoiu (2013); and (iii) assigning a larger share to lead banks (30 percent to mandated arrangers and 40 percent to bookrunners, representing the sample averages associated with these bank roles in our data) ("average-to-lead") in the spirit of de Haas and van Horen (2013). Then we pool the data over 2006-2010 for all lenders and sum up the bank-specific loan volumes at the country-pair level.

In Table A1 we report the cumulative share of lending associated with the top 100, top 200, top 300, etc. country-pairs, by loan origination amount, and the ratio between the total loan amount obtained from each imputation method and that obtained from the reported shares. We find that the average ratio between imputed and actual loan origination volume, where the imputation is the simple pro-rata rule, is 0.98 for the top 100 country pairs (by loan origination amount), which account for 41.6 percent of global issuance. Looking further down, the average ratio is 0.99 and 1 for country pairs that account up to 73.8 percent of global origination amount, and becomes 1.06 for country pairs that account for 94.2 percent. 
This suggests that for country-pairs that contribute small amounts to loan origination the biases become larger and tend to be positive; however, this pattern is common to all imputation methods.

Table A1 suggests that the errors associated with the pro-rata imputation method at the country-pair level of aggregation are not systematically worse than alternative methods and stay within error bounds that we deem acceptable for purposes of our analysis.

Table A1. Imputing loan shares, 2006-2010

\begin{tabular}{lcccc}
\hline & $(1)$ & $(2)$ & $(3)$ & $(4)$ \\
\cline { 2 - 5 } & $\begin{array}{c}\text { Cumulative share } \\
\text { in total lending }\end{array}$ & (i) Pro-rata & (ii) Regression & $\begin{array}{c}\text { (iii) Average-to- } \\
\text { lead }\end{array}$ \\
\cline { 2 - 5 } top 100 country pairs & $41.6 \%$ & 0.98 & 0.99 & 0.98 \\
top 200 country pairs & $54.3 \%$ & 0.99 & 0.99 & 0.99 \\
top 300 country pairs & $62.9 \%$ & 1.00 & 1.01 & 0.99 \\
top 400 country pairs & $69.0 \%$ & 1.00 & 1.00 & 0.98 \\
top 500 country pairs & $73.8 \%$ & 1.00 & 1.00 & 0.98 \\
top 1000 country pairs & $94.2 \%$ & 1.06 & 1.04 & 1.03 \\
Median & & & & 1.01 \\
\hline
\end{tabular}

Notes: Column 1 shows the cumulative share of total loan origination contributed by the top 100, top 200, top 300 , etc. country-pairs in terms of loan volume up to 94.2 percent of global issuance. Columns 2-4 report the average ratio between the total loan origination volume (based on reported loan shares) and the loan origination volume obtained by imputing the missing loan shares using three alternative methods. Sources: Dealogic Loan Analytics.

\section{B. Structure and evolution of the syndicated loan market (1995-2012)}

In Figure A1 we present charts on the structure (borrower composition, currency composition, loan terms for AE vs. EME borrowers, cross-border vs. domestic loans) for the syndicated loan market during 1995-2012. Cross-border loans are defined as loans in which at least one syndicate member is a foreign bank (that is, that its nationality is different from the borrower's nationality) (Gadanecz and von Kleist, 2002). 
Figure A1. The syndicated loan market, 1995-2012

A. Number of deals by borrower type

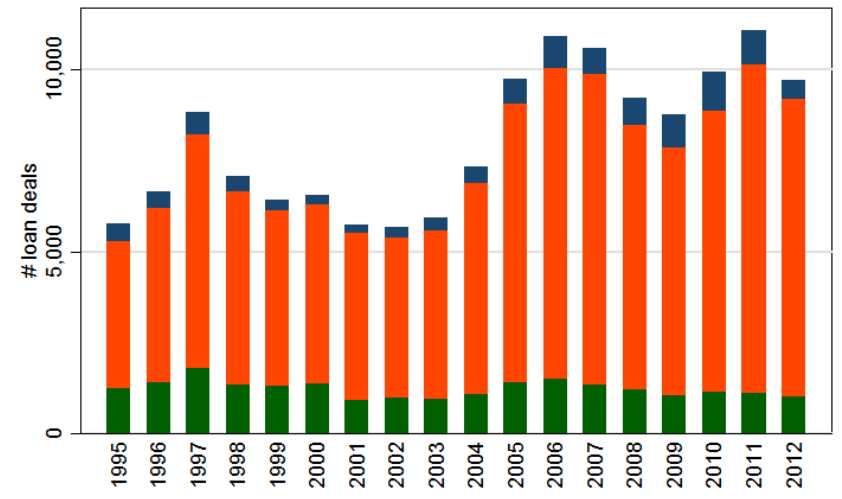

\begin{tabular}{|l|l|}
\hline Financial & Non-financial \\
Sovereign
\end{tabular}

C. Deal size: AE vs. EME borrowers

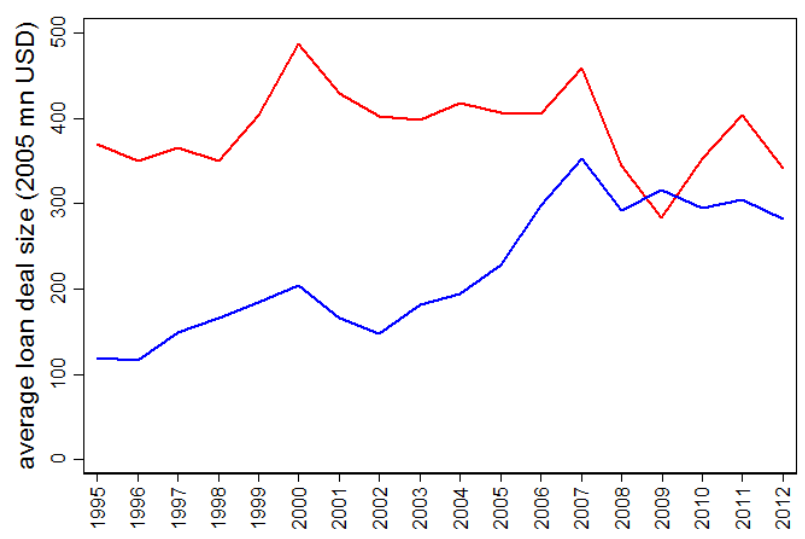

AE borrowers — EME borrowers

E. Deal price: AE vs. EME borrowers

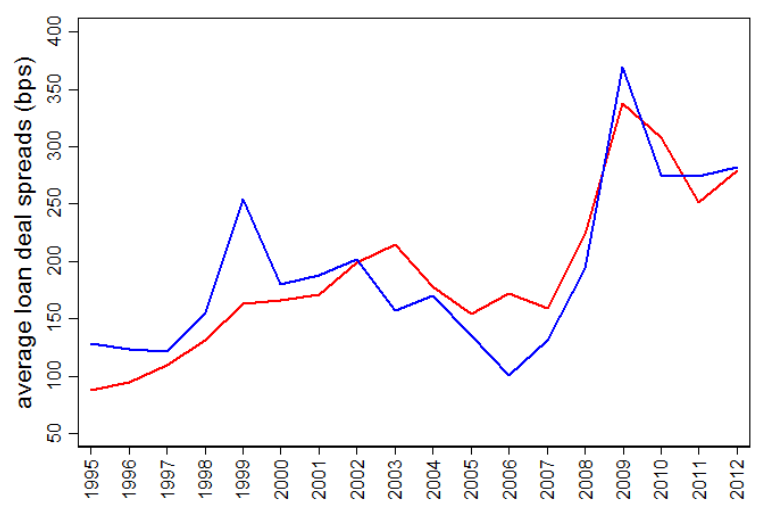

- $\mathrm{AE}$ borrowers — EME borrowers
B. Number of deals by currency
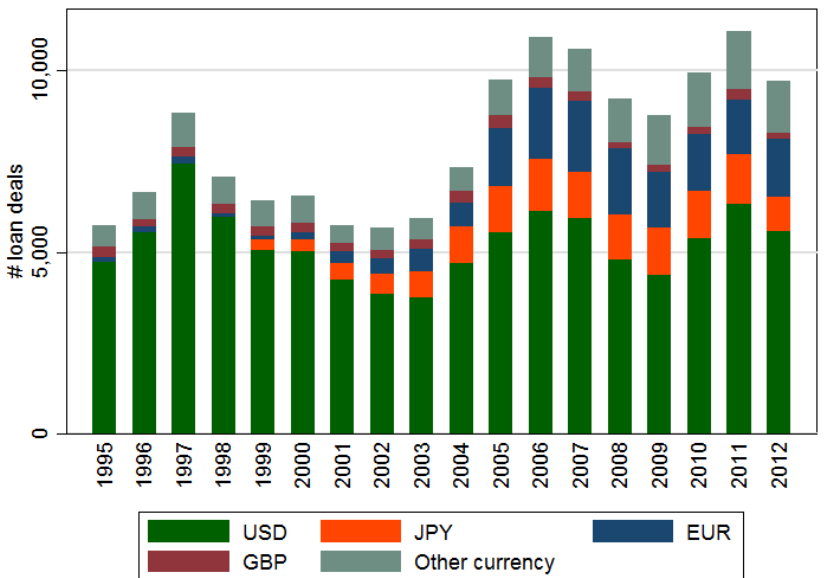

D. Deal maturity: AE vs. EME borrowers

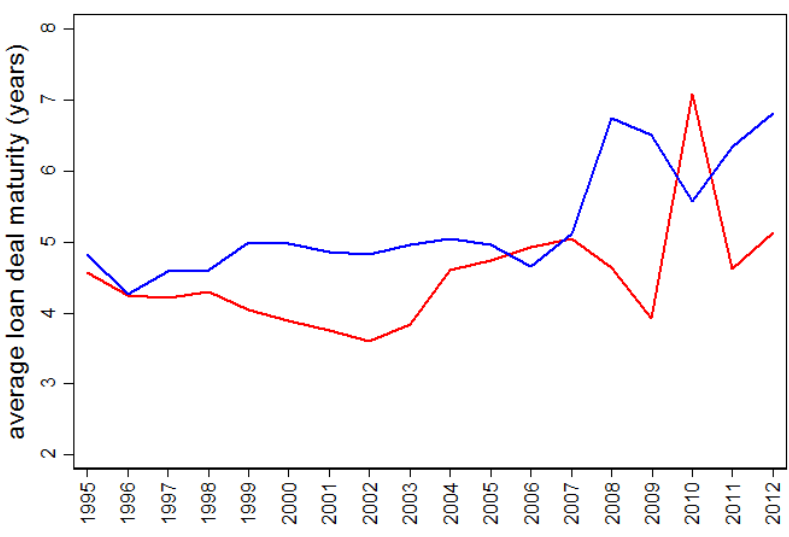

- AE borrowers — EME borrowers

F. Deal size: Domestic vs. cross-border loans

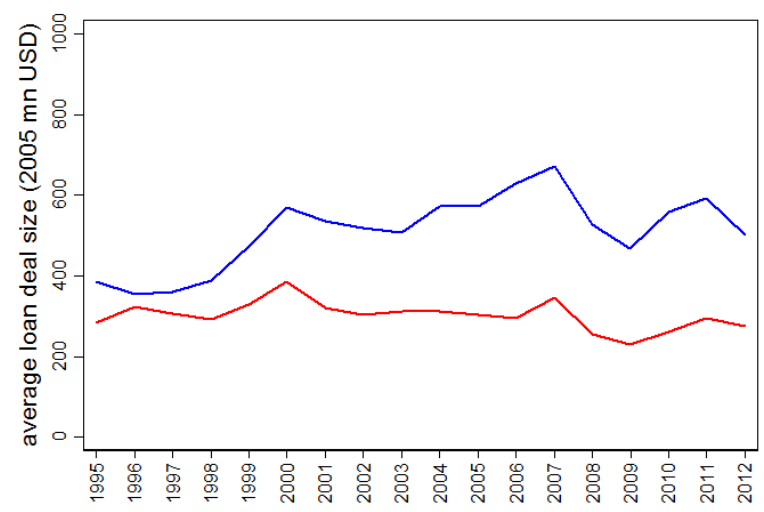

Domestic loans $\longrightarrow$ Cross-border loans 
G. Deal maturity: Domestic vs. cross-border loans

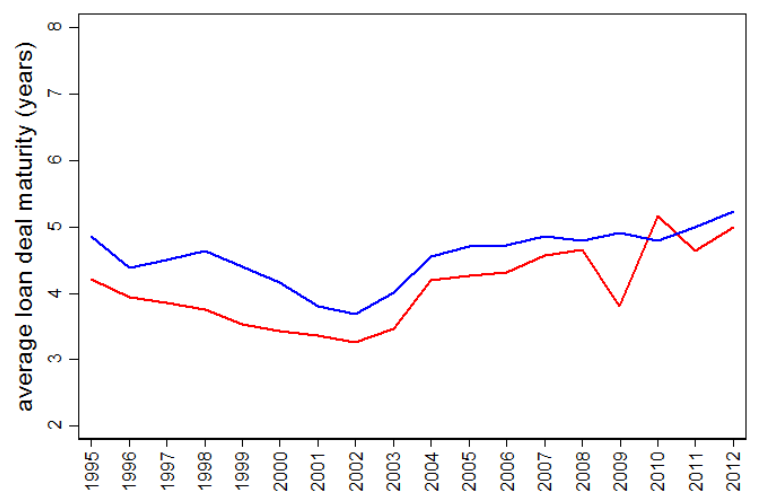

I. Borrower concentration:

Gini coefficient

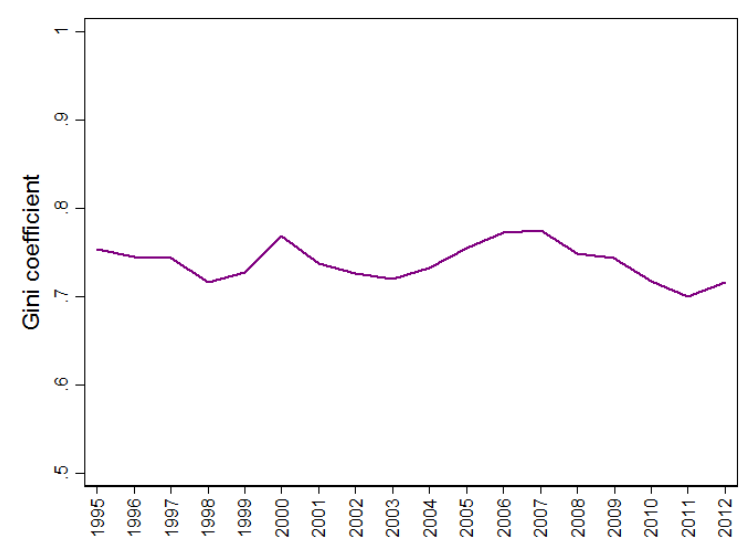

K. Syndicate size

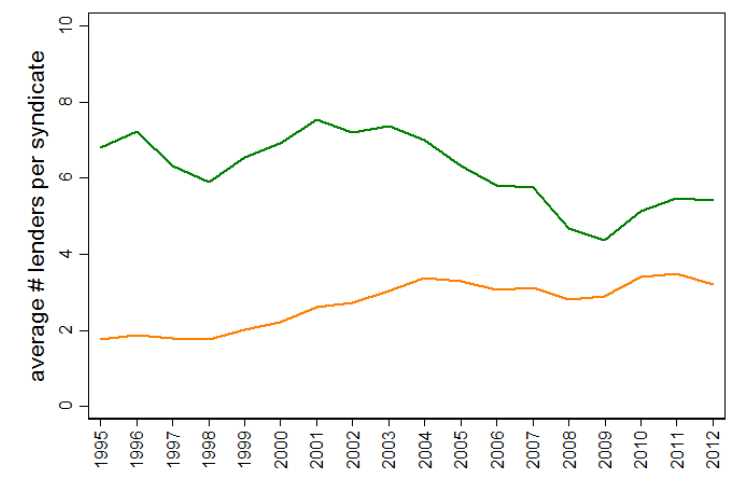

- All lenders $\longrightarrow$ Lead banks
H. Deal price: Domestic vs. cross-border loans

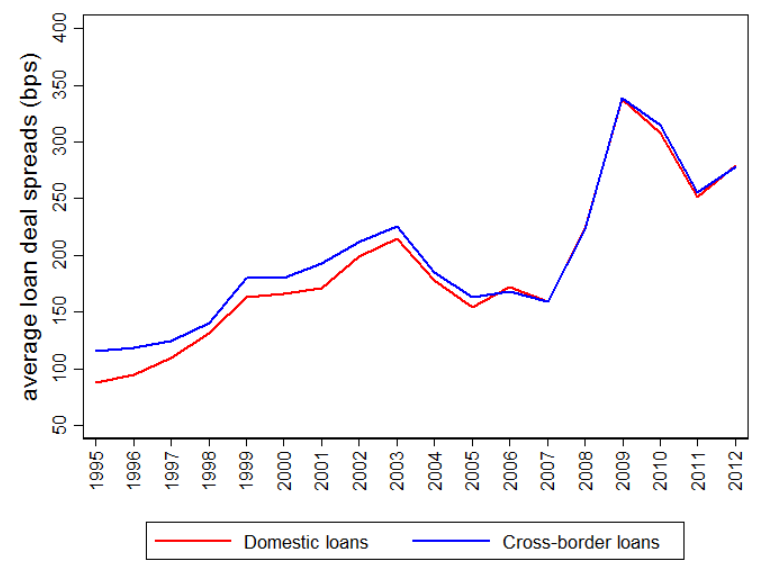

J. Borrower concentration:

Market share of largest 100 borrowers

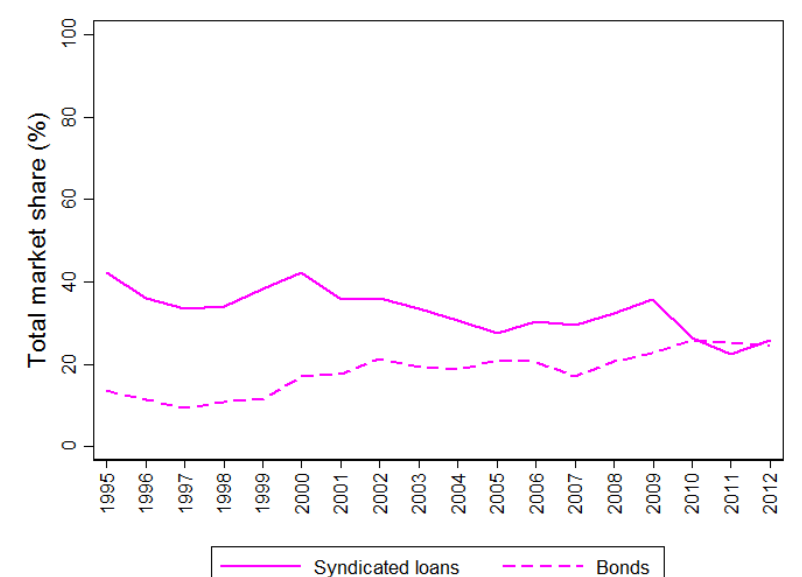

L. Domestic vs. foreign borrower deals

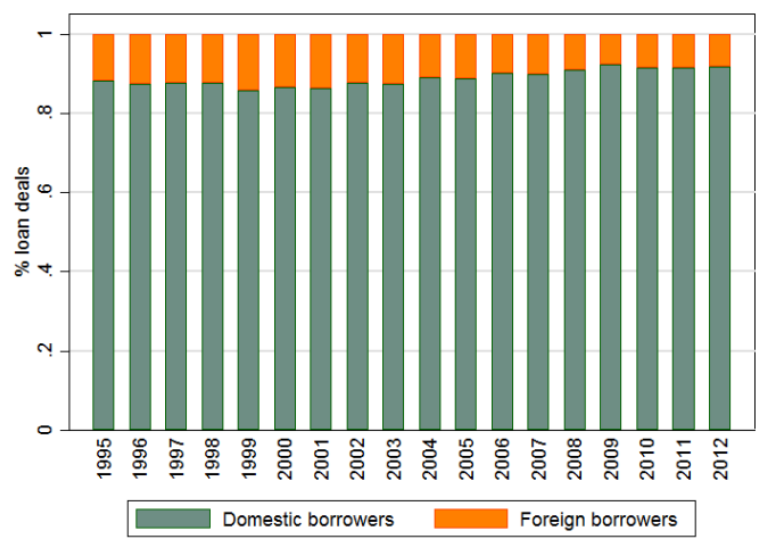

Notes: In Panels E and H, deal prices are average spreads (in basis points) over LIBOR for 5-year loans. In Panel F, G, and $\mathrm{H}$, cross-border loans are defined as loans for which at least one lender does not have the same nationality as the borrower. Panel I shows the Gini coefficient for the distribution of total deal amounts by individual borrowers. Panel J shows the total market share of the largest 100 borrowers (respectively, loan issuers). Both borrower concentration measures are computed at the borrower parent level. In Panel K "lead banks" refer to bookrunners and mandated arrangers. In Panel L "foreign borrowers" are borrowers whose nationality is different from their parent's nationality. Source: Dealogic Loan Analytics. 


\section{BIS International Banking Statistics}

The BIS IBS track internationally active banks' foreign positions through two main datasets: the BIS Consolidated Banking Statistics (CBS) and the BIS Locational Banking Statistics (LBS). For detailed information on these data sources, see Cerutti, Claessens, and McGuire (2012) and BIS (2009).

Locational Banking Statistics (LBS): The LBS captures the activities of all internationally active offices in a reporting country regardless of the nationality of the parent bank, with bank positions recorded on an unconsolidated basis-including those vis-à-vis their own offices in other countries. LBS data are residence-based (i.e., they follow balance-of-payments accounting). Bank positions are broken down by currency, sector (bank and non-bank), country of residence of the counterparty and nationality of reporting banks. Both domestically-owned and foreign-owned banking offices in reporting countries record their positions on a gross (unconsolidated) basis, including positions vis-à-vis own affiliates in other countries. See https://www.bis.org/statistics/bankstats.htm for more information on the LBS.

Consolidated Banking Statistics (CBS): The CBS track banks' worldwide consolidated gross claims and other exposures to individual countries and sectors. Before being aggregated at the creditor banking system -level, the bank-level data is based on domestically-owned banking group data for which intergroup positions are netted out and consolidated across offices worldwide. An advantage of the CBS is that banks separately report off-balance sheet items such as derivative contracts and contingent exposures (undisbursed credit commitments and guarantees). A disadvantage-and the reason why we do not use the CBS for our regression analysis-is that the available series are only consistent from the mid-2000s onwards. See https://www.bis.org/statistics/consstats.htm for more information on the CBS.

\section{AdJUSTMENTS to BIS AND LoAn ANALYTICS Data}

We performed four adjustments to our syndicated loan data to make the Loan Analytics SLEs comparable to the BIS total loan claims. These are: (i) aggregating syndicated loan data following the same criteria used in the case of CBS and LBS; (ii) comparing the same type of exposures-loans with loans; (iii) ensuring the same reporting group — only banks as lenders; and (iv) adjusting syndicated loan data for the fact that a large part of the loan commitments (credit lines) may not be drawn and would thus represent off-balance sheet exposures.

\section{A. Aggregating Syndicated Loans on a Consolidated and Locational Basis}

We use the individual lender and borrower nationalities, lender parent nationality, and loan amounts and maturities to construct SLEs at the individual lender-borrower level and then aggregate them at the lender-borrower country-pair level. We construct two bilateral SLE series: one that aggregates the data on a consolidated basis and the other on a locational basis. The latter series is the starting point for examining the relative importance of the loan syndication market in total cross-border loan exposures. 
Figure A2 shows a comparison between BIS locational claims and the estimated SLEs (before any adjustments) aggregated at the lender-borrower country pair level on locational basis.

Figure A2. Syndicated loan exposures and BIS total claims (trillions of U.S. dollars), 1995-2012

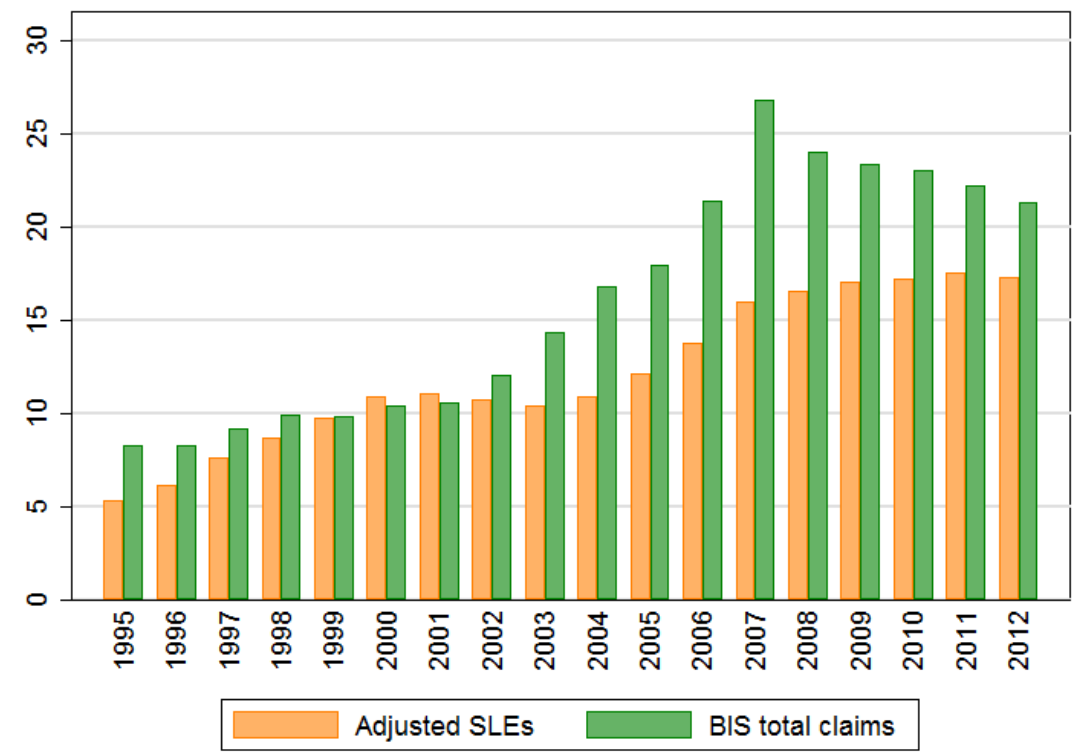

Notes: The chart shows (unadjusted) SLEs and total BIS total claims during 1995-2012. Figures are expressed in trillions of constant U.S. dollars (2005 prices). Sources: Dealogic's Loan Analytics, BIS locational banking statistics (Table 7A).

\section{B. Comparing the Same Type of Exposures: Loans with Loans}

The two series plotted in Figure A2 are not fully comparable. One reason is that the total BIS claims include not only bank loans, but also holdings of securities and other bank assets. As an intermediate step in moving towards a correct comparison with SLEs, we focus on the component of BIS claims that refers to bank loans only (BIS Table 6a). This comparison is shown in Figure 1 of the paper.

\section{Ensuring the Same Reporting Group: Banks vs. Non-Banks}

To further improve the comparability of the SLE series with the BIS total loan claims, we need to adjust the reporting entities in the SLE series. The BIS IBS only reports cross-border exposures of banks, which means that they exclude non-bank institutional lenders. However, these lenders often participate in syndicated loans, and their importance in the market has increased during the 2000s (Nandy and Shao, 2010; Nini, 2008). Loans extended by non-bank institutional lenders inflate our estimated SLEs. We can adjust the SLEs to reflect bank lending only by exploiting information about loan type. Syndicated loans that are reported as either credit lines or "Term Loan A"-type loans are extended almost exclusively by banks (Culp, 2013; Benmelech, Duglosz, and Ivashina, 2012; Nandy and Shao, 2010; Yago and 
McCarthy, 2004). Therefore, we further adjust the SLEs to retain only credit lines and term loans of type A. The latter represent, on average, 8 percent of total term loan volume over 1995-2012.

\section{Estimating Credit Line Usage Rates}

Many syndicated loan deals involve credit lines that are not fully drawn over the life of the loan. Undrawn credit lines amounts at a given point of time are recorded as off-balance sheet commitments. This means that they are not included in the LBS, which only refer to bank's on-balance sheet claims. The last adjustment needed to obtain fully comparable series concerns estimating credit line usage rates and applying them to our SLEs to remove the off-balance sheet component.

To estimate credit line usage rates, we compare the BIS undrawn portion of credit lines (available from the CBS for 18 reporting countries over 2005-2012) with syndicated credit lines on a consolidated basis. Under the assumption that most undrawn cross-border credit lines are syndicated (as opposed to bilateral), the ratio between BIS undrawn credit lines and (total) syndicated credit lines give us an estimate of (1-utilization rate). Our calculations indicate that utilization rates on syndicated credit lines increased from 2005 to 2012 from 25.6 percent to 52.1 percent (Table A2). We compute credit line usage rates for each year and borrower country. For 1995-2004 and each borrower country, we assume a credit line usage rate equal to the 2005-2007 average for that country.

These estimates are generally consistent with evidence that US firms' access to unused credit lines is linked to the business cycle, rising by about 17 percentage points when credit conditions are tight (Mian and Santos, 2012); and that significant credit line drawdowns by US firms started with the unfolding of the US subprime crisis (Berrospide and Meisenzahl, 2013). Correa, Sapriza, and Zlate (2013) document a usage ratio of about one third for US branches of foreign banks in 2010. While our credit line drawdown estimates are not directly comparable to those from earlier studies because of differences in data sources and methodology, we are reassured that the uncovered trend is consistent with the literature. 
Table A2. Average credit line usage rates, 2005-2012

\begin{tabular}{ccccccc}
\hline & $(1)$ & $(2)$ & $(3)$ & $(4)$ & $(5)$ & $(6)$ \\
\cline { 2 - 7 } & All borrowers & AE borrowers & EME borrowers & US firms & $\begin{array}{c}\text { US firms, } \\
\text { alternative source }\end{array}$ & Non-US firms \\
\cline { 2 - 7 } 2005 & 25.65 & 28.69 & 27.96 & 36.44 & 32.08 & 24.65 \\
2006 & 28.12 & 32.95 & 27.73 & 34.97 & 33.40 & 27.92 \\
2007 & 25.14 & 24.22 & 23.21 & 43.65 & 36.70 & 24.24 \\
2008 & 39.62 & 43.65 & 37.30 & 51.96 & 43.31 & 38.25 \\
2009 & 40.20 & 36.78 & 47.35 & 62.93 & 54.25 & 39.26 \\
2010 & 50.46 & 49.51 & 50.00 & 62.49 & 48.03 & 49.85 \\
2011 & 57.40 & 56.90 & 50.61 & 68.74 & 44.29 & 56.83 \\
2012 & 52.16 & 52.74 & 52.40 & 66.16 & 44.52 & 51.17 \\
\hline
\end{tabular}

Notes: Average credit line usage rates for columns 1-4 are obtained by comparing BIS off-balance sheet credit commitments and syndicated credit lines, both on a consolidated basis, over 2005-2012. The BIS off-balance sheet credit commitments are available for 18 reporting countries. Calculations are based on the data for which both variables were not missing and not zero. In column 5 credit line usage rates are obtained by comparing data on total outstanding and committed balances from the Shared National Credits Program 2013 Review, which collects information on syndicated loans to US borrowers in excess of 20 million U.S. dollars with at least three lenders (see http://www.federalreserve.gov/newsevents/press/bcreg/bcreg20131010a1.pdf, Appendix A, p. 10.). Sources: Dealogic Loan Analytics, BIS consolidated banking statistics, and Shared National Credits Program.

\section{E. Breaking Down Total Cross-Border Loan Exposures}

Total cross-border loan exposures comprise syndicated, bilateral, and intragroup loan exposures. In previous sections, we estimated SLEs. To gauge the size of intragroup lending, we analyze the breakdown of banks' international positions from the BIS locational statistics into the following components: assets vis-à-vis related offices, assets vis-à-vis unrelated banks, assets vis-à-vis non-banks, and assets vis-à-vis official monetary authorities (see Figure A3). We find that assets vis-à-vis related offices, which are indicative of intragroup lending activities, represented almost 30 percent of total loan exposures during 1995-2012.

Under the assumption that intragroup loans are rarely syndicated, we obtain cross-border bilateral loan exposures as the difference between BIS total loan claims, syndicated loan exposures, and intragroup loan exposures. Figure A4 plots the composition of cross-border bank loan claims based on this assumption. Figure A4 shows that during 1995-2012 syndicated loan exposures, bilateral loan exposures, and intragroup loan exposures each accounted for roughly one third of total cross-border bank loan claims. 
Figure A3. Composition of banks' international positions, 1995-2012

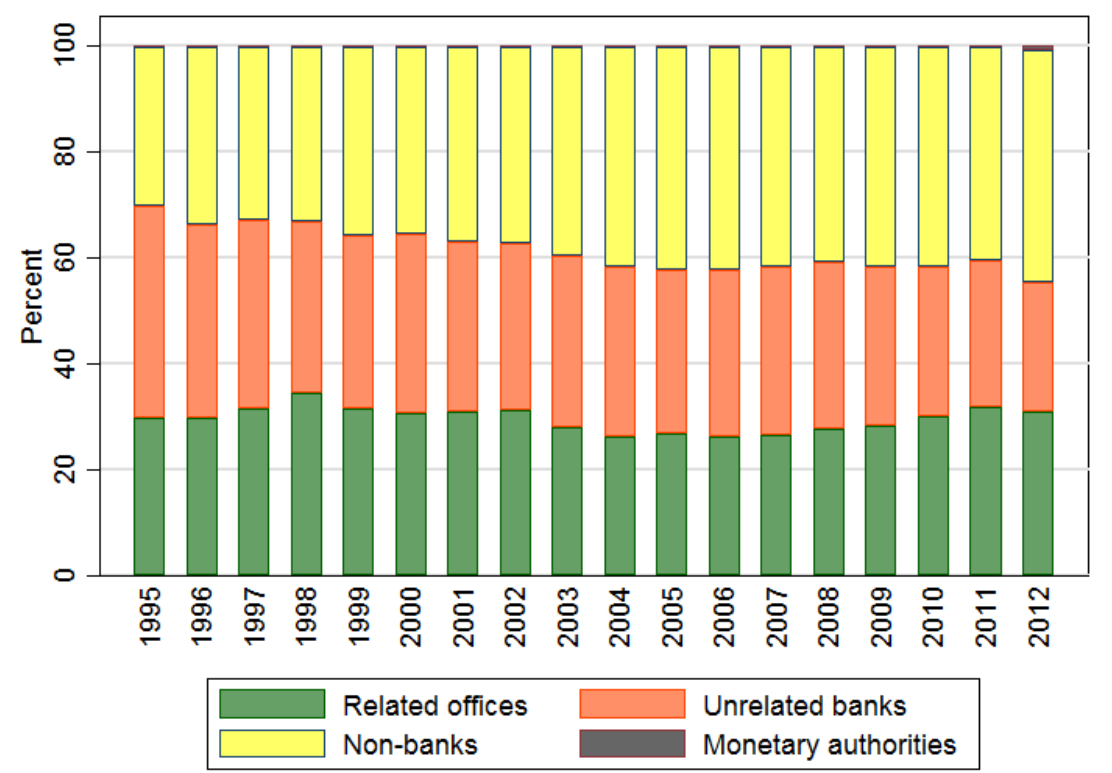

Source: BIS locational banking statistics (Table 8A).

Figure A4. Composition of bank cross-border loan exposures (trillions of U.S. dollars), 1995-2012

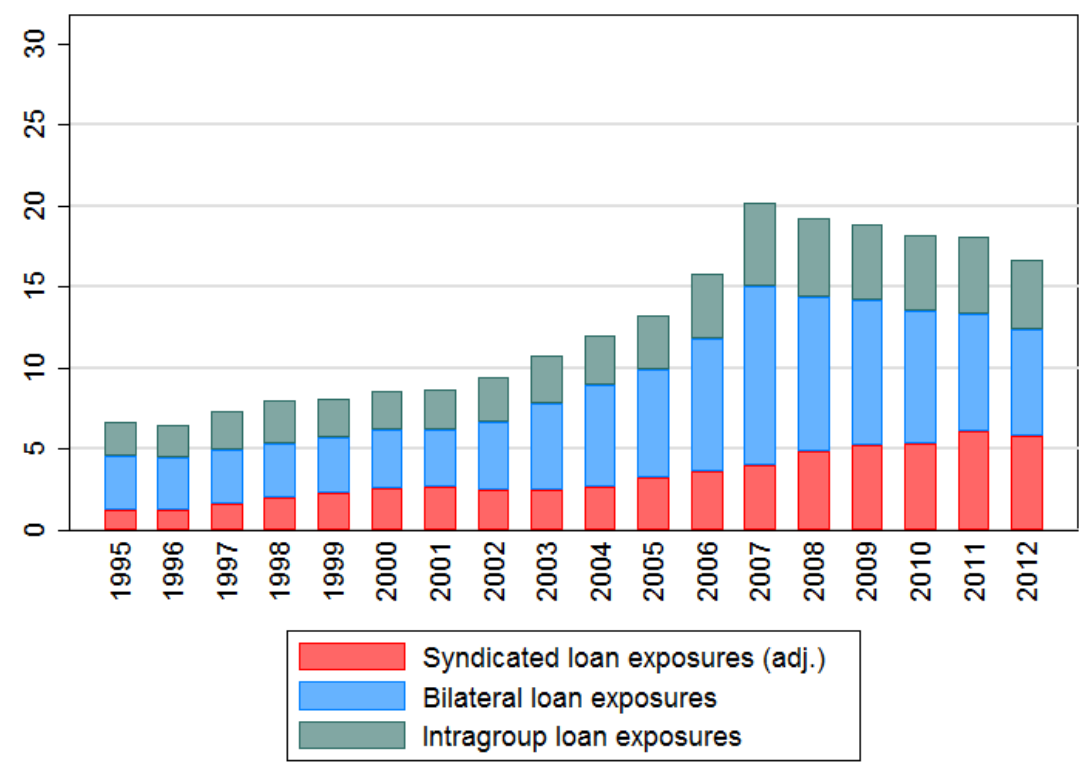

Notes: All figures are expressed in trillions of constant U.S. dollars (2005 prices). The figure is based on rough estimates that assume intragroup loans not to be syndicated. Bank cross-border claims on national monetary authorities are ignored for simplicity. Sources: Dealogic Loan Analytics and BIS locational banking statistics. 


\section{ADDITIONAL RESULTS}

Table B1. Co-movement between (unadjusted) SLEs and BIS total loan claims

\begin{tabular}{|c|c|c|c|c|c|c|c|c|}
\hline \multirow{3}{*}{$\begin{array}{l}\text { A. All } \\
\text { Log-SLE-Total }\end{array}$} & (1) & (2) & (3) & \multirow{3}{*}{$\begin{array}{c}(4) \\
\text { Before } \\
2008 \\
\\
0.652^{* * *} \\
(0.055)\end{array}$} & (5) & (6) & (7) & \multirow{3}{*}{$\begin{array}{c}(8) \\
\text { Before } \\
2008 \\
\end{array}$} \\
\hline & \multicolumn{3}{|c|}{ Full sample period } & & \multicolumn{3}{|c|}{ Full sample period } & \\
\hline & $\begin{array}{c}0.897^{\star \star *} \\
(0.042)\end{array}$ & $\begin{array}{l}0.901^{* * *} \\
(0.042)\end{array}$ & $\begin{array}{c}0.653^{* * *} \\
(0.050)\end{array}$ & & & & & \\
\hline Log-SLE-Credit lines & & & & & $\begin{array}{c}0.458^{\star \star *} \\
(0.031)\end{array}$ & $\begin{array}{c}0.458^{\star \star \star} \\
(0.031)\end{array}$ & $\begin{array}{c}0.273^{\star \star *} \\
(0.022)\end{array}$ & $\begin{array}{c}0.263^{\star * *} \\
(0.025)\end{array}$ \\
\hline Log-SLE-Term loans & & & & & $\begin{array}{c}0.359^{\star * *} \\
(0.045)\end{array}$ & $\begin{array}{c}0.362^{* * *} \\
(0.045)\end{array}$ & $\begin{array}{c}0.345^{\star * *} \\
(0.033)\end{array}$ & $\begin{array}{c}0.353^{\star * *} \\
(0.035)\end{array}$ \\
\hline $\begin{array}{l}\text { Observations } \\
\text { R-squared }\end{array}$ & $\begin{array}{c}28,251 \\
0.494\end{array}$ & $\begin{array}{c}28,251 \\
0.498\end{array}$ & $\begin{array}{c}28,251 \\
0.720\end{array}$ & $\begin{array}{c}19,323 \\
0.741\end{array}$ & $\begin{array}{c}28,251 \\
0.498\end{array}$ & $\begin{array}{c}28,251 \\
0.502\end{array}$ & $\begin{array}{c}28,251 \\
0.722\end{array}$ & $\begin{array}{c}19,323 \\
0.742\end{array}$ \\
\hline \multicolumn{9}{|l|}{ B. AE borrowers } \\
\hline Log-SLE-Total & $\begin{array}{c}0.873^{\star * *} \\
(0.054)\end{array}$ & $\begin{array}{c}0.878^{* * *} \\
(0.054)\end{array}$ & $\begin{array}{c}0.658^{\star * *} \\
(0.074)\end{array}$ & $\begin{array}{c}0.685^{\star * *} \\
(0.082)\end{array}$ & & & & \\
\hline Log-SLE-Credit lines & & & & & $\begin{array}{c}0.426^{\star * *} \\
(0.048)\end{array}$ & $\begin{array}{c}0.434^{* * *} \\
(0.047)\end{array}$ & $\begin{array}{c}0.289^{* * *} \\
(0.040)\end{array}$ & $\begin{array}{c}0.284^{* * *} \\
(0.043)\end{array}$ \\
\hline Log-SLE-Term loans & & & & & $\begin{array}{c}0.370^{\star * *} \\
(0.067)\end{array}$ & $\begin{array}{c}0.365^{\star * *} \\
(0.066)\end{array}$ & $\begin{array}{c}0.315^{\star * *} \\
(0.041)\end{array}$ & $\begin{array}{c}0.335^{\star * *} \\
(0.047)\end{array}$ \\
\hline Observations & 11,439 & 11,439 & 11,439 & 7,899 & 11,439 & 11,439 & 11,439 & 7,899 \\
\hline R-squared & 0.516 & 0.521 & 0.755 & 0.772 & 0.512 & 0.517 & 0.754 & 0.770 \\
\hline \multicolumn{9}{|l|}{ C. EME borrowers } \\
\hline Log-SLE-Total & $\begin{array}{c}0.827^{\star \star \star} \\
(0.039)\end{array}$ & $\begin{array}{c}0.827^{\star \star *} \\
(0.039)\end{array}$ & $\begin{array}{c}0.686^{\star * *} \\
(0.058)\end{array}$ & $\begin{array}{c}0.694^{\star * *} \\
(0.063)\end{array}$ & & & & \\
\hline Log-SLE-Credit lines & & & & & $\begin{array}{c}0.338^{\star * *} \\
(0.032)\end{array}$ & $\begin{array}{c}0.329^{\star * *} \\
(0.032)\end{array}$ & $\begin{array}{c}0.238^{\star * *} \\
(0.025)\end{array}$ & $\begin{array}{c}0.236^{* \star *} \\
(0.029)\end{array}$ \\
\hline Log-SLE-Term loans & & & & & $\begin{array}{c}0.434^{\star * *} \\
(0.038)\end{array}$ & $\begin{array}{c}0.443^{\star * *} \\
(0.037)\end{array}$ & $\begin{array}{c}0.421^{* * *} \\
(0.049)\end{array}$ & $\begin{array}{c}0.431^{* * *} \\
(0.049)\end{array}$ \\
\hline Observations & 11,951 & 11,951 & 11,951 & 8,153 & 11,951 & 11,951 & 11,951 & 8,153 \\
\hline R-squared & 0.465 & 0.471 & 0.643 & 0.664 & 0.472 & 0.478 & 0.647 & 0.666 \\
\hline Year FE & no & yes & yes & yes & no & yes & yes & yes \\
\hline Country-pair FE & no & no & yes & yes & no & no & yes & yes \\
\hline
\end{tabular}

Notes: The dependent variable is log-BIS cross-border bank loan claims. The sample period is 1995-2012. See Table 2 for variable definitions and sources. 
Figure B1. Share of SLEs in BIS total loan claims, 1995-2012

\section{A. By lender}

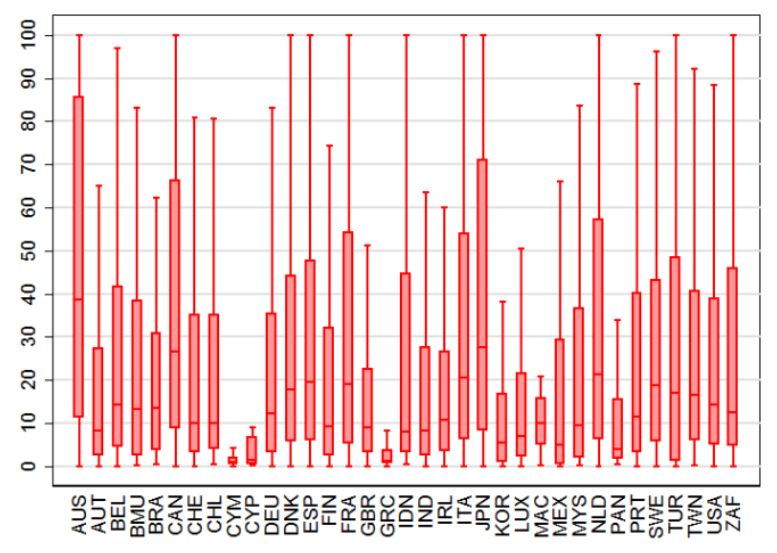

\section{By EME borrower}

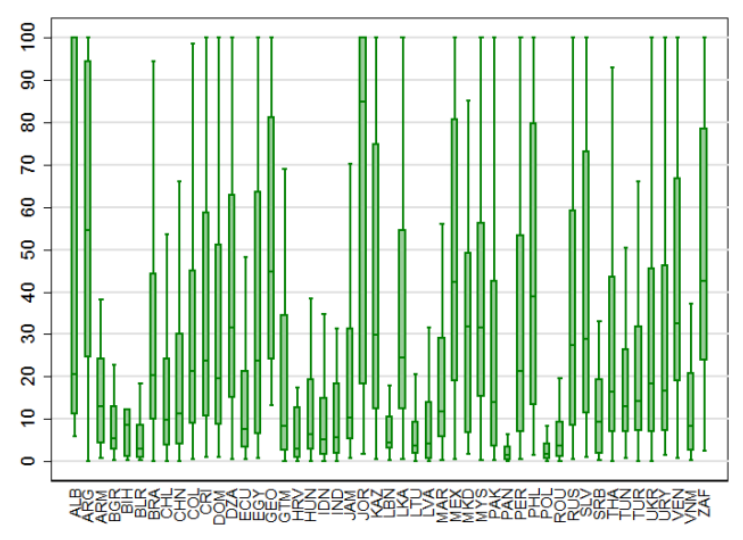

\section{B. By AE borrower}

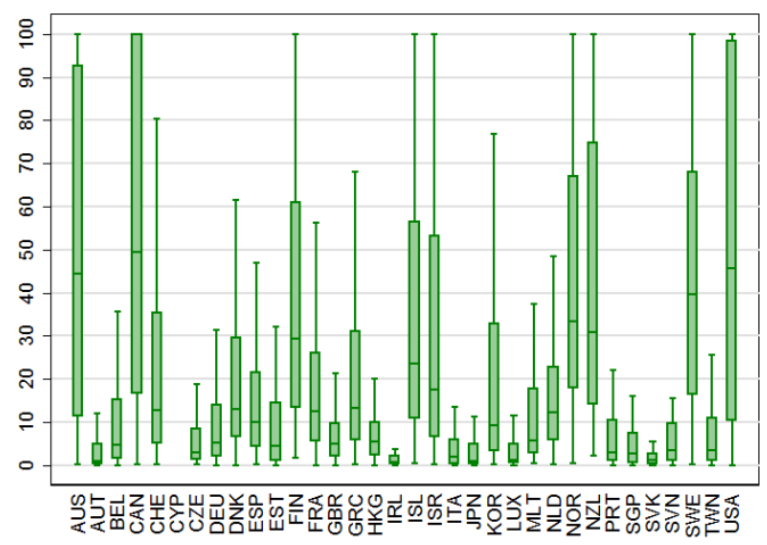

D. By year

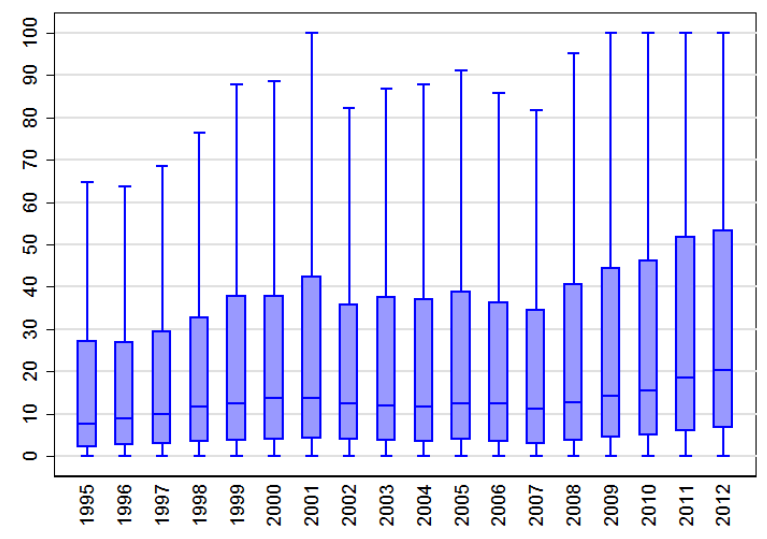

Notes: The figures show the distribution of the share of adjusted SLEs in BIS cross-border bank loan claims by lender country (Panel A), borrower country (Panels B and C) and year (Panel D). The sample includes all country pairs with (non-zero) cross-border syndicated activity. SLEs are adjusted for maximum comparability with BIS total loan claims (see manuscript and Appendix for details). The bars show the inter-quantile range with the median indicated by a horizontal line; the bars extend from the minimum to the maximum value of the ratio. The ratio is top-winsorized at the 90 th percentile. 


\section{Table B2. Unconditional correlation matrices for selected regression variables}

\begin{tabular}{|c|c|c|c|c|c|c|c|c|c|c|c|}
\hline A. Syndicated loan exposures & Log-SLE & Log-real trade & $\begin{array}{l}\text { 1: Common } \\
\text { language }\end{array}$ & $\begin{array}{l}\text { Log- } \\
\text { geographical } \\
\text { distance }\end{array}$ & $\begin{array}{l}\text { 1. Foreign } \\
\text { affiliate }\end{array}$ & $\begin{array}{l}\text { Lender log-pc } \\
\text { GDP }\end{array}$ & $\begin{array}{l}\text { Lender bank } \\
\text { assets (\% } \\
\text { GDP) }\end{array}$ & $\begin{array}{l}\text { Lender bank } \\
\text { capita-to- } \\
\text { assets }\end{array}$ & $\begin{array}{l}\text { Borrower log- } \\
\text { pc GDP }\end{array}$ & $\begin{array}{c}\text { Borrower } \\
\text { bank assets } \\
\text { (\% GDP) }\end{array}$ & $\begin{array}{l}\text { Borrower } \\
\text { institutional } \\
\text { quality }\end{array}$ \\
\hline Log-real trade & $0.6079^{*}$ & 1 & & & & & & & & & \\
\hline 1: Common language & $0.1216^{*}$ & $0.1451^{*}$ & 1 & & & & & & & & \\
\hline Log-geographical distance & $-0.2430^{\star}$ & $-0.2943^{\star}$ & 0.0188 & 1 & & & & & & & \\
\hline 1. Foreign affiliate & $0.3611^{*}$ & $0.3922^{*}$ & $0.2149^{*}$ & $-0.0459^{\star}$ & 1 & & & & & & \\
\hline Lender log-pc GDP & $0.1691^{*}$ & $-0.0987^{\star}$ & -0.0227 & $-0.0515^{\star}$ & 0.0196 & 1 & & & & & \\
\hline Lender bank assets (\% GDP) & $0.0868^{*}$ & $-0.0662^{*}$ & $-0.1198^{*}$ & -0.0219 & $0.0420^{*}$ & $0.2462^{*}$ & 1 & & & & \\
\hline Lender bank capita-to-assets & $-0.0596^{*}$ & 0.0114 & $-0.0790^{*}$ & -0.0162 & 0.0129 & $-0.0818^{*}$ & $0.0311^{*}$ & 1 & & & \\
\hline Borrower log-pc GDP & $0.3669^{*}$ & $0.3135^{\star}$ & -0.0268 & $-0.4811^{*}$ & $0.1567^{*}$ & -0.021 & 0.0028 & $0.0281^{*}$ & 1 & & \\
\hline Borrower bank assets (\% GDP) & $0.3462^{*}$ & $0.3791^{*}$ & 0.0217 & $-0.3008^{*}$ & $0.2144^{*}$ & -0.0251 & $0.0292^{*}$ & 0.009 & $0.6165^{\star}$ & 1 & \\
\hline Borrower institutional quality & $0.2159^{*}$ & $0.1272^{*}$ & $0.0404^{*}$ & $-0.2467^{*}$ & $0.1200^{*}$ & -0.0026 & $-0.0511^{*}$ & -0.0226 & $0.4677^{*}$ & $0.2802^{*}$ & 1 \\
\hline Borrower capital acct openness & $0.2026^{*}$ & $0.1260^{*}$ & $0.0575^{\star}$ & $-0.3836^{*}$ & $0.1051^{*}$ & 0.0033 & -0.0159 & -0.0065 & $0.6483^{*}$ & $0.3927^{*}$ & $0.5528^{*}$ \\
\hline $\begin{array}{c}\text { B. Non-syndicated loan } \\
\text { exposures }\end{array}$ & Log-non-SLE & Log-real trade & $\begin{array}{l}\text { 1: Common } \\
\text { language }\end{array}$ & $\begin{array}{c}\text { Log- } \\
\text { geographical } \\
\text { distance }\end{array}$ & $\begin{array}{l}\text { 1. Foreign } \\
\text { affiliate }\end{array}$ & $\begin{array}{l}\text { Lender log-pc } \\
\text { GDP }\end{array}$ & $\begin{array}{c}\text { Lender bank } \\
\text { assets (\% } \\
\text { GDP) }\end{array}$ & $\begin{array}{c}\text { Lender bank } \\
\text { capita-to- } \\
\text { assets } \\
\end{array}$ & $\begin{array}{l}\text { Borrower log- } \\
\text { pc GDP }\end{array}$ & $\begin{array}{c}\text { Borrower } \\
\text { bank assets } \\
(\% \text { GDP }) \\
\end{array}$ & $\begin{array}{c}\text { Borrower } \\
\text { institutional } \\
\text { quality }\end{array}$ \\
\hline Log-real trade & $0.5975^{\star}$ & 1 & & & & & & & & & \\
\hline 1: Common language & $0.1159^{*}$ & $0.1451^{*}$ & 1 & & & & & & & & \\
\hline Log-geographical distance & $-0.4817^{*}$ & $-0.2943^{*}$ & 0.0188 & 1 & & & & & & & \\
\hline 1. Foreign affiliate & $0.3680^{*}$ & $0.3922^{*}$ & $0.2149^{\star}$ & $-0.0459^{*}$ & 1 & & & & & & \\
\hline Lender log-pc GDP & $0.1472^{*}$ & $-0.0987^{\star}$ & -0.0227 & $-0.0515^{\star}$ & 0.0196 & 1 & & & & & \\
\hline Lender bank assets (\% GDP) & $0.0615^{\star}$ & $-0.0662^{*}$ & $-0.1198^{*}$ & -0.0219 & $0.0420^{*}$ & $0.2462^{*}$ & 1 & & & & \\
\hline Lender bank capita-to-assets & $-0.0714^{*}$ & 0.0114 & $-0.0790^{\star}$ & -0.0162 & 0.0129 & $-0.0818^{*}$ & $0.0311^{*}$ & 1 & & & \\
\hline Borrower log-pc GDP & $0.4942^{*}$ & $0.3135^{\star}$ & -0.0268 & $-0.4811^{*}$ & $0.1567^{\star}$ & -0.021 & 0.0028 & $0.0281^{*}$ & 1 & & \\
\hline Borrower bank assets (\% GDP) & $0.4739^{\star}$ & $0.3791^{*}$ & 0.0217 & $-0.3008^{*}$ & $0.2144^{*}$ & -0.0251 & $0.0292^{*}$ & 0.009 & $0.6165^{\star}$ & 1 & \\
\hline Borrower institutional quality & $0.2488^{*}$ & $0.1272^{*}$ & $0.0404^{*}$ & $-0.2467^{\star}$ & $0.1200^{*}$ & -0.0026 & $-0.0511^{*}$ & -0.0226 & $0.4677^{*}$ & $0.2802^{*}$ & 1 \\
\hline Borrower capital acct openness & $0.3434^{*}$ & $0.1260^{*}$ & $0.0575^{\star}$ & $-0.3836^{*}$ & $0.1051^{*}$ & 0.0033 & -0.0159 & -0.0065 & $0.6483^{*}$ & $0.3927^{*}$ & $0.5528^{*}$ \\
\hline
\end{tabular}

Notes: * indicates statistical significance at the 1 percent level. Correlations are computed for the regression sample. See Table 2 for variable definitions and sources. 
Table B3. Drivers of syndicated and non-syndicated loan exposures - Interactions with GFC - AE borrowers

\begin{tabular}{|c|c|c|c|c|c|c|c|c|c|c|c|c|}
\hline \multirow[b]{3}{*}{ Log-real trade } & (1) & (2) & (3) & (4) & (5) & (6) & (7) & (8) & (9) & $(10)$ & (11) & (12) \\
\hline & \multicolumn{6}{|c|}{ Dependent variable: Log-SLE } & \multicolumn{6}{|c|}{ Dependent variable: Log-non-SLE } \\
\hline & $\begin{array}{c}0.194^{* * *} \\
(0.033)\end{array}$ & $\begin{array}{c}0.203^{\star \star \star} \\
(0.034)\end{array}$ & $\begin{array}{c}0.203^{* \star *} \\
(0.034)\end{array}$ & $\begin{array}{c}0.204^{\star \star *} \\
(0.034)\end{array}$ & $\begin{array}{c}0.203^{* \star *} \\
(0.034)\end{array}$ & $\begin{array}{c}0.194^{* * *} \\
(0.033)\end{array}$ & $\begin{array}{l}0.150^{* \star *} \\
(0.036)\end{array}$ & $\begin{array}{c}0.159^{\star \star *} \\
(0.038)\end{array}$ & $\begin{array}{c}0.159^{\star \star \star} \\
(0.038)\end{array}$ & $\begin{array}{c}0.159^{\star * *} \\
(0.038)\end{array}$ & $\begin{array}{c}0.159^{\star * *} \\
(0.038)\end{array}$ & $\begin{array}{c}0.146^{\star \star *} \\
(0.036)\end{array}$ \\
\hline 1: Common language & $\begin{array}{c}0.187^{*} \\
(0.111)\end{array}$ & $\begin{array}{l}0.197^{\star} \\
(0.112)\end{array}$ & $\begin{array}{l}0.194^{\star} \\
(0.112)\end{array}$ & $\begin{array}{l}0.194^{*} \\
(0.112)\end{array}$ & $\begin{array}{l}0.196^{*} \\
(0.112)\end{array}$ & $\begin{array}{l}0.184^{*} \\
(0.111)\end{array}$ & $\begin{array}{c}0.050 \\
(0.143)\end{array}$ & $\begin{array}{c}0.057 \\
(0.144)\end{array}$ & $\begin{array}{c}0.057 \\
(0.144)\end{array}$ & $\begin{array}{c}0.059 \\
(0.145)\end{array}$ & $\begin{array}{c}0.058 \\
(0.145)\end{array}$ & $\begin{array}{c}0.049 \\
(0.143)\end{array}$ \\
\hline Log-geographical distance & $\begin{array}{c}-0.525^{* * *} \\
(0.078)\end{array}$ & $\begin{array}{c}-0.537^{\star * *} \\
(0.078)\end{array}$ & $\begin{array}{c}-0.553^{* * *} \\
(0.079)\end{array}$ & $\begin{array}{c}-0.553^{* * *} \\
(0.079)\end{array}$ & $\begin{array}{c}-0.553^{\star \star *} \\
(0.079)\end{array}$ & $\begin{array}{c}-0.515^{\star * *} \\
(0.077)\end{array}$ & $\begin{array}{c}-0.845^{* * *} \\
(0.084)\end{array}$ & $\begin{array}{c}-0.899^{* * *} \\
(0.087)\end{array}$ & $\begin{array}{c}-0.875^{\star \star *} \\
(0.085)\end{array}$ & $\begin{array}{c}-0.876^{* * *} \\
(0.086)\end{array}$ & $\begin{array}{c}-0.876^{* * *} \\
(0.085)\end{array}$ & $\begin{array}{c}-0.887^{\text {** }} \\
(0.085)\end{array}$ \\
\hline 1: Foreign affiliate & $\begin{array}{c}0.410^{\star \star *} \\
(0.078)\end{array}$ & $\begin{array}{c}0.405^{\star \star *} \\
(0.078)\end{array}$ & $\begin{array}{c}0.406^{\star \star *} \\
(0.078)\end{array}$ & $\begin{array}{c}0.406^{\star \star *} \\
(0.078)\end{array}$ & $\begin{array}{c}0.406^{\star \star *} \\
(0.078) \\
\end{array}$ & $\begin{array}{c}0.411^{\star \star *} \\
(0.077)\end{array}$ & $\begin{array}{c}0.749^{\star \star * *} \\
(0.098)\end{array}$ & $\begin{array}{c}0.744^{* \star \star} \\
(0.098)\end{array}$ & $\begin{array}{c}0.745^{\star \star \star \star} \\
(0.098) \\
\end{array}$ & $\begin{array}{c}0.744^{\star \star *} \\
(0.098)\end{array}$ & $\begin{array}{c}0.744^{\star * *} \\
(0.098)\end{array}$ & $\begin{array}{c}0.751^{* \star *} \\
(0.097)\end{array}$ \\
\hline \multicolumn{13}{|l|}{ Lender characteristics } \\
\hline Log-per capita GDP & $\begin{array}{c}0.003 \\
(0.445)\end{array}$ & $\begin{array}{l}-0.279 \\
(0.451)\end{array}$ & $\begin{array}{l}-0.234 \\
(0.447)\end{array}$ & $\begin{array}{l}-0.246 \\
(0.451)\end{array}$ & $\begin{array}{l}-0.249 \\
(0.450)\end{array}$ & $\begin{array}{l}-0.019 \\
(0.447)\end{array}$ & $\begin{array}{l}0.665^{*} \\
(0.403)\end{array}$ & $\begin{array}{c}0.459 \\
(0.397)\end{array}$ & $\begin{array}{c}0.423 \\
(0.397)\end{array}$ & $\begin{array}{c}0.403 \\
(0.397)\end{array}$ & $\begin{array}{c}0.407 \\
(0.398)\end{array}$ & $\begin{array}{l}0.827^{* *} \\
(0.410)\end{array}$ \\
\hline Bank assets (\% GDP) & $\begin{array}{l}-0.000 \\
(0.001)\end{array}$ & $\begin{array}{l}-0.000 \\
(0.001)\end{array}$ & $\begin{array}{l}-0.000 \\
(0.001)\end{array}$ & $\begin{array}{l}-0.000 \\
(0.001)\end{array}$ & $\begin{array}{l}-0.000 \\
(0.001)\end{array}$ & $\begin{array}{l}-0.000 \\
(0.001)\end{array}$ & $\begin{array}{l}-0.001 \\
(0.001)\end{array}$ & $\begin{array}{l}-0.001 \\
(0.001)\end{array}$ & $\begin{array}{l}-0.001 \\
(0.001)\end{array}$ & $\begin{array}{l}-0.001 \\
(0.001)\end{array}$ & $\begin{array}{l}-0.001 \\
(0.001)\end{array}$ & $\begin{array}{l}-0.001 \\
(0.001)\end{array}$ \\
\hline Bank capital-to-assets ratio & $\begin{array}{l}-0.050^{\star *} \\
(0.020)\end{array}$ & $\begin{array}{l}-0.051^{* *} \\
(0.020)\end{array}$ & $\begin{array}{c}-0.064^{\star \star \star} \\
(0.020)\end{array}$ & $\begin{array}{c}-0.055^{\star * *} \\
(0.020)\end{array}$ & $\begin{array}{c}-0.055^{\star * *} \\
(0.020)\end{array}$ & $\begin{array}{c}-0.059^{* * *} \\
(0.020)\end{array}$ & $\begin{array}{c}0.021 \\
(0.023)\end{array}$ & $\begin{array}{c}0.011 \\
(0.023)\end{array}$ & $\begin{array}{c}0.007 \\
(0.022)\end{array}$ & $\begin{array}{c}0.016 \\
(0.023)\end{array}$ & $\begin{array}{c}0.015 \\
(0.023)\end{array}$ & $\begin{array}{c}0.017 \\
(0.023)\end{array}$ \\
\hline Log-total other lending & $\begin{array}{c}0.660^{* * *} \\
(0.058)\end{array}$ & $\begin{array}{c}0.654^{\star * *} \\
(0.054)\end{array}$ & $\begin{array}{c}0.651^{* * *} \\
(0.055)\end{array}$ & $\begin{array}{c}0.644^{\star \star \star} \\
(0.055)\end{array}$ & $\begin{array}{c}0.647^{\star \star \star} \\
(0.055)\end{array}$ & $\begin{array}{c}0.647^{\star \star \star} \\
(0.059)\end{array}$ & $\begin{array}{c}-0.124^{*} \\
(0.058)\end{array}$ & $\begin{array}{c}-0.140^{\star *} \\
(0.062)\end{array}$ & $\begin{array}{c}-0.129^{* *} \\
(0.060)\end{array}$ & $\begin{array}{c}-0.124^{* *} \\
(0.060)\end{array}$ & $\begin{array}{l}-0.131^{\star *} \\
(0.061)\end{array}$ & $\begin{array}{c}-0.141^{\star *} \\
(0.062)\end{array}$ \\
\hline \multicolumn{13}{|l|}{ Borrower characteristics } \\
\hline$\overline{\text { Log-per capita GDP }}$ & $\begin{array}{l}-0.578 \\
(0.487)\end{array}$ & $\begin{array}{l}-0.901^{*} \\
(0.471)\end{array}$ & $\begin{array}{l}-0.845^{*} \\
(0.475)\end{array}$ & $\begin{array}{l}-0.871^{*} \\
(0.473)\end{array}$ & $\begin{array}{l}-0.864^{\star} \\
(0.471)\end{array}$ & $\begin{array}{l}-0.666 \\
(0.494)\end{array}$ & $\begin{array}{c}1.977^{\star \star *} \\
(0.572)\end{array}$ & $\begin{array}{c}1.828^{\star \star *} \\
(0.587)\end{array}$ & $\begin{array}{c}1.726^{* * *} \\
(0.578)\end{array}$ & $\begin{array}{c}1.714^{\star \star \star} \\
(0.578)\end{array}$ & $\begin{array}{c}1.720^{\star \star \star} \\
(0.580)\end{array}$ & $\begin{array}{c}2.264^{* * *} \\
(0.587)\end{array}$ \\
\hline Bank assets (\% GDP) & $\begin{array}{c}0.001 \\
(0.001)\end{array}$ & $\begin{array}{c}0.001 \\
(0.001)\end{array}$ & $\begin{array}{c}0.001 \\
(0.001)\end{array}$ & $\begin{array}{c}0.001 \\
(0.001)\end{array}$ & $\begin{array}{c}0.001 \\
(0.001)\end{array}$ & $\begin{array}{c}0.001 \\
(0.001)\end{array}$ & $\begin{array}{l}0.004^{\star * *} \\
(0.001)\end{array}$ & $\begin{array}{l}0.003^{\star \star \star} \\
(0.001)\end{array}$ & $\begin{array}{c}0.003^{\star \star *} \\
(0.001)\end{array}$ & $\begin{array}{c}0.003^{\star \star \star} \\
(0.001)\end{array}$ & $\begin{array}{l}0.004^{\star \star \star} \\
(0.001)\end{array}$ & $\begin{array}{l}0.004^{* * *} \\
(0.001)\end{array}$ \\
\hline Institutional quality & $\begin{array}{c}0.033 \\
(0.065)\end{array}$ & $\begin{array}{c}0.017 \\
(0.066)\end{array}$ & $\begin{array}{c}0.005 \\
(0.065)\end{array}$ & $\begin{array}{c}0.000 \\
(0.066)\end{array}$ & $\begin{array}{c}0.016 \\
(0.065)\end{array}$ & $\begin{array}{c}0.045 \\
(0.065)\end{array}$ & $\begin{array}{l}0.161^{*} \\
(0.088)\end{array}$ & $\begin{array}{c}0.119 \\
(0.086)\end{array}$ & $\begin{array}{c}0.135 \\
(0.087)\end{array}$ & $\begin{array}{c}0.138 \\
(0.086)\end{array}$ & $\begin{array}{l}0.153^{*} \\
(0.086)\end{array}$ & $\begin{array}{l}0.147^{*} \\
(0.087)\end{array}$ \\
\hline Capital account openness & $\begin{array}{c}0.004 \\
(0.005)\end{array}$ & $\begin{array}{c}0.004 \\
(0.005)\end{array}$ & $\begin{array}{c}0.004 \\
(0.005)\end{array}$ & $\begin{array}{c}0.003 \\
(0.005)\end{array}$ & $\begin{array}{c}0.004 \\
(0.005)\end{array}$ & $\begin{array}{c}0.003 \\
(0.005)\end{array}$ & $\begin{array}{l}-0.003 \\
(0.005)\end{array}$ & $\begin{array}{l}-0.005 \\
(0.005)\end{array}$ & $\begin{array}{l}-0.004 \\
(0.005)\end{array}$ & $\begin{array}{l}-0.003 \\
(0.005)\end{array}$ & $\begin{array}{l}-0.004 \\
(0.005)\end{array}$ & $\begin{array}{l}-0.005 \\
(0.005)\end{array}$ \\
\hline Log-total other borrowing & $\begin{array}{c}0.178^{\star \star \star} \\
(0.052) \\
\end{array}$ & $\begin{array}{c}0.207^{\star \star \star} \\
(0.055)\end{array}$ & $\begin{array}{c}0.183^{* \star \star} \\
(0.054) \\
\end{array}$ & $\begin{array}{c}0.194^{\star \star *} \\
(0.053) \\
\end{array}$ & $\begin{array}{c}0.192^{\star * *} \\
(0.053) \\
\end{array}$ & $\begin{array}{c}0.178^{\star \star \star} \\
(0.053) \\
\end{array}$ & $\begin{array}{l}-0.016 \\
(0.096)\end{array}$ & $\begin{array}{l}-0.019 \\
(0.099)\end{array}$ & $\begin{array}{l}-0.012 \\
(0.100)\end{array}$ & $\begin{array}{c}0.007 \\
(0.097)\end{array}$ & $\begin{array}{c}0.007 \\
(0.097)\end{array}$ & $\begin{array}{l}-0.073 \\
(0.100)\end{array}$ \\
\hline \multicolumn{13}{|l|}{ GFC and interactions } \\
\hline Log-real trade*GFC & $\begin{array}{c}0.119^{\star \star *} \\
(0.026)\end{array}$ & & & & & $\begin{array}{c}0.112^{\star \star *} \\
(0.028)\end{array}$ & $\begin{array}{c}0.125^{\star \star \star} \\
(0.031)\end{array}$ & & & & & $\begin{array}{c}0.158^{* * \star} \\
(0.033)\end{array}$ \\
\hline Geographical distance*GFC & & $\begin{array}{l}-0.057 \\
(0.038)\end{array}$ & & & & $\begin{array}{l}-0.042 \\
(0.046)\end{array}$ & & $\begin{array}{l}0.086^{*} \\
(0.046)\end{array}$ & & & & $\begin{array}{c}0.182^{* * *} \\
(0.055)\end{array}$ \\
\hline Bank capital-to-assets ratio*GFC & & & $\begin{array}{c}0.028^{*} \\
(0.017)\end{array}$ & & & $\begin{array}{l}0.033^{*} \\
(0.020)\end{array}$ & & & $\begin{array}{c}0.025 \\
(0.026)\end{array}$ & & & $\begin{array}{l}-0.012 \\
(0.028)\end{array}$ \\
\hline Capital account openness ${ }^{*}$ GFC & & & & $\begin{array}{c}-0.014 \\
(0.015)\end{array}$ & & $\begin{array}{l}-0.020 \\
(0.015)\end{array}$ & & & & $\begin{array}{c}0.010 \\
(0.014)\end{array}$ & & $\begin{array}{c}0.018 \\
(0.013)\end{array}$ \\
\hline Institutional quality ${ }^{*} \mathrm{GFC}$ & & & & & $\begin{array}{l}-0.023 \\
(0.018) \\
\end{array}$ & $\begin{array}{l}-0.031^{*} \\
(0.018)\end{array}$ & & & & & $\begin{array}{l}-0.035^{*} \\
(0.018)\end{array}$ & $\begin{array}{l}-0.017 \\
(0.020)\end{array}$ \\
\hline Observations & 4,601 & 4,601 & 4,601 & 4,601 & 4,601 & 4,601 & 4,601 & 4,601 & 4,601 & 4,601 & 4,601 & 4,601 \\
\hline R-squared & 0.855 & 0.853 & 0.853 & 0.853 & 0.853 & 0.855 & 0.764 & 0.763 & 0.762 & 0.762 & 0.762 & 0.765 \\
\hline
\end{tabular}

Notes: The dependent variable is log-SLE (columns 1-6) and log-non-SLE (columns 7-12). Sample period: 1995-2012. All regressions include year and country fixed effects. Standard errors are clustered on country pair. See Table 2 for variable definitions and sources. 
Table B4. Drivers of syndicated and non-syndicated loan exposures - Interactions with GFC - EME borrowers

\begin{tabular}{|c|c|c|c|c|c|c|c|c|c|c|c|c|}
\hline & (1) & (2) & (3) & $(4)$ & (5) & (6) & (7) & (8) & (9) & $(10)$ & (11) & (12) \\
\hline & \multicolumn{6}{|c|}{ Dependent variable: Log-SLE } & \multicolumn{6}{|c|}{ Dependent variable: Log-non-SLE } \\
\hline Log-real trade & $\begin{array}{c}0.223^{\star \star \star} \\
(0.071)\end{array}$ & $\begin{array}{c}0.229^{\star \star \star} \\
(0.070)\end{array}$ & $\begin{array}{c}0.229^{\star \star *} \\
(0.070)\end{array}$ & $\begin{array}{c}0.229^{\star \star \star} \\
(0.070)\end{array}$ & $\begin{array}{c}0.231^{\star \star *} \\
(0.070)\end{array}$ & $\begin{array}{c}0.216^{\star \star \star} \\
(0.071)\end{array}$ & $\begin{array}{c}0.436^{\star \star \star} \\
(0.071)\end{array}$ & $\begin{array}{c}0.430^{\star \star \star} \\
(0.069)\end{array}$ & $\begin{array}{c}0.433^{\star \star \star} \\
(0.069)\end{array}$ & $\begin{array}{c}0.432^{\star \star *} \\
(0.068)\end{array}$ & $\begin{array}{c}0.436^{\star * *} \\
(0.069)\end{array}$ & $\begin{array}{c}0.436^{\star \star \star} \\
(0.069)\end{array}$ \\
\hline 1: Common language & $\begin{array}{c}0.542^{\star * *} \\
(0.186)\end{array}$ & $\begin{array}{c}0.542^{* * \star} \\
(0.187)\end{array}$ & $\begin{array}{c}0.542^{* * *} \\
(0.186)\end{array}$ & $\begin{array}{c}0.540^{* * *} \\
(0.186)\end{array}$ & $\begin{array}{c}0.539 * * \star \\
(0.186)\end{array}$ & $\begin{array}{c}0.540^{\star \star *} \\
(0.186)\end{array}$ & $\begin{array}{c}0.611^{\star * \star} \\
(0.155)\end{array}$ & $\begin{array}{c}0.609^{\star * \star} \\
(0.155)\end{array}$ & $\begin{array}{c}0.612^{* * *} \\
(0.155)\end{array}$ & $\begin{array}{c}0.604^{* * *} \\
(0.154)\end{array}$ & $\begin{array}{c}0.604^{* \star *} \\
(0.154)\end{array}$ & $\begin{array}{l}0.599^{\star \star \star} \\
(0.154)\end{array}$ \\
\hline Log-geographical distance & $\begin{array}{c}-0.510^{\star \star \star} \\
(0.136)\end{array}$ & $\begin{array}{c}-0.488^{\star * *} \\
(0.139)\end{array}$ & $\begin{array}{c}-0.511^{\star \star \star} \\
(0.136)\end{array}$ & $\begin{array}{c}-0.510^{\star \star \star} \\
(0.136)\end{array}$ & $\begin{array}{c}-0.507^{\star \star \star} \\
(0.136)\end{array}$ & $\begin{array}{c}-0.503^{\star \star \star} \\
(0.141)\end{array}$ & $\begin{array}{c}-0.853^{\star \star \star} \\
(0.121)\end{array}$ & $\begin{array}{c}-0.770^{\star \star \star} \\
(0.122)\end{array}$ & $\begin{array}{c}-0.854^{\star \star \star} \\
(0.120)\end{array}$ & $\begin{array}{c}-0.850^{* \star *} \\
(0.120)\end{array}$ & $\begin{array}{c}-0.848^{\star \star \star} \\
(0.120)\end{array}$ & $\begin{array}{c}-0.762^{\star \star \star} \\
(0.122)\end{array}$ \\
\hline 1: Foreign affiliate & $\begin{array}{c}0.466^{* * *} \\
(0.097)\end{array}$ & $\begin{array}{c}0.460^{* \star *} \\
(0.097) \\
\end{array}$ & $\begin{array}{c}0.464^{* \star *} \\
(0.097) \\
\end{array}$ & $\begin{array}{c}0.461^{* * *} \\
(0.096)\end{array}$ & $\begin{array}{c}0.463^{* * *} \\
(0.097)\end{array}$ & $\begin{array}{c}0.458^{\star * \star} \\
(0.096) \\
\end{array}$ & $\begin{array}{c}0.581^{* * *} \\
(0.089) \\
\end{array}$ & $\begin{array}{c}0.561^{* * *} \\
(0.089) \\
\end{array}$ & $\begin{array}{c}0.582^{* * *} \\
(0.089) \\
\end{array}$ & $\begin{array}{c}0.576^{* \star *} \\
(0.089) \\
\end{array}$ & $\begin{array}{c}0.576^{* * *} \\
(0.089) \\
\end{array}$ & $\begin{array}{c}0.553^{\star * *} \\
(0.088) \\
\end{array}$ \\
\hline \multicolumn{13}{|l|}{ Lender characteristics } \\
\hline Log-per capita GDP & $\begin{array}{l}-0.477 \\
(0.476)\end{array}$ & $\begin{array}{l}-0.605 \\
(0.471)\end{array}$ & $\begin{array}{l}-0.562 \\
(0.471)\end{array}$ & $\begin{array}{l}-0.538 \\
(0.468)\end{array}$ & $\begin{array}{l}-0.566 \\
(0.476)\end{array}$ & $\begin{array}{l}-0.462 \\
(0.465)\end{array}$ & $\begin{array}{l}-0.396 \\
(0.523)\end{array}$ & $\begin{array}{l}-0.562 \\
(0.526)\end{array}$ & $\begin{array}{l}-0.357 \\
(0.515)\end{array}$ & $\begin{array}{l}-0.346 \\
(0.519)\end{array}$ & $\begin{array}{l}-0.390 \\
(0.519)\end{array}$ & $\begin{array}{l}-0.617 \\
(0.538)\end{array}$ \\
\hline Bank assets (\% GDP) & $\begin{array}{c}0.001 \\
(0.001)\end{array}$ & $\begin{array}{l}0.001 \\
(0.001)\end{array}$ & $\begin{array}{c}0.001 \\
(0.001)\end{array}$ & $\begin{array}{c}0.001 \\
(0.001)\end{array}$ & $\begin{array}{l}0.000 \\
(0.001)\end{array}$ & $\begin{array}{c}0.001 \\
(0.001)\end{array}$ & $\begin{array}{l}0.002^{*} \\
(0.001)\end{array}$ & $\begin{array}{l}0.003^{\star *} \\
(0.001)\end{array}$ & $\begin{array}{l}0.002^{*} \\
(0.001)\end{array}$ & $\begin{array}{l}0.002^{* *} \\
(0.001)\end{array}$ & $\begin{array}{l}0.002^{*} \\
(0.001)\end{array}$ & $\begin{array}{l}0.003^{* *} \\
(0.001)\end{array}$ \\
\hline Bank capital-to-assets ratio & $\begin{array}{c}-0.048^{\star *} \\
(0.022)\end{array}$ & $\begin{array}{c}-0.048^{* *} \\
(0.022)\end{array}$ & $\begin{array}{l}-0.043^{*} \\
(0.022)\end{array}$ & $\begin{array}{c}-0.046^{\star *} \\
(0.022)\end{array}$ & $\begin{array}{c}-0.048^{* *} \\
(0.022)\end{array}$ & $\begin{array}{l}-0.037^{*} \\
(0.022)\end{array}$ & $\begin{array}{l}-0.049^{*} \\
(0.025)\end{array}$ & $\begin{array}{c}-0.050^{* *} \\
(0.025)\end{array}$ & $\begin{array}{l}-0.050^{*} \\
(0.026)\end{array}$ & $\begin{array}{l}-0.047^{*} \\
(0.025)\end{array}$ & $\begin{array}{l}-0.049^{*} \\
(0.025)\end{array}$ & $\begin{array}{l}-0.047^{*} \\
(0.026)\end{array}$ \\
\hline Log-total other lending & $\begin{array}{l}0.594^{* * *} \\
(0.038)\end{array}$ & $\begin{array}{l}0.586^{* * *} \\
(0.038)\end{array}$ & $\begin{array}{c}0.591^{* * *} \\
(0.038)\end{array}$ & $\begin{array}{l}0.580^{* * *} \\
(0.038)\end{array}$ & $\begin{array}{c}0.580^{\star \star \star *} \\
(0.036)\end{array}$ & $\begin{array}{l}0.572^{\star \star \star *} \\
(0.037)\end{array}$ & $\begin{array}{c}0.180^{\star \star \star} \\
(0.046)\end{array}$ & $\begin{array}{c}0.144^{* * *} \\
(0.046)\end{array}$ & $\begin{array}{c}0.181^{* * *} \\
(0.045)\end{array}$ & $\begin{array}{l}0.148^{\star * *} \\
(0.049)\end{array}$ & $\begin{array}{l}0.157^{\star \star \star} \\
(0.047)\end{array}$ & $\begin{array}{l}0.107^{\star \star} \\
(0.050)\end{array}$ \\
\hline \multicolumn{13}{|l|}{ Borrower characteristics } \\
\hline$\overline{\text { Log-per capita GDP }}$ & $\begin{array}{l}-0.063 \\
(0.295)\end{array}$ & $\begin{array}{l}-0.052 \\
(0.294)\end{array}$ & $\begin{array}{l}-0.052 \\
(0.296)\end{array}$ & $\begin{array}{c}0.007 \\
(0.296)\end{array}$ & $\begin{array}{l}-0.019 \\
(0.297)\end{array}$ & $\begin{array}{c}0.002 \\
(0.295)\end{array}$ & $\begin{array}{c}0.086 \\
(0.279)\end{array}$ & $\begin{array}{c}0.109 \\
(0.278)\end{array}$ & $\begin{array}{c}0.080 \\
(0.281)\end{array}$ & $\begin{array}{c}0.184 \\
(0.280)\end{array}$ & $\begin{array}{c}0.157 \\
(0.277)\end{array}$ & $\begin{array}{c}0.229 \\
(0.275)\end{array}$ \\
\hline Bank assets (\% GDP) & $\begin{array}{c}0.003 \\
(0.002)\end{array}$ & $\begin{array}{c}0.003 \\
(0.002)\end{array}$ & $\begin{array}{c}0.003 \\
(0.002)\end{array}$ & $\begin{array}{l}0.004^{*} \\
(0.002)\end{array}$ & $\begin{array}{l}0.003^{*} \\
(0.002)\end{array}$ & $\begin{array}{l}0.004^{\star *} \\
(0.002)\end{array}$ & $\begin{array}{l}0.008^{\star \star \star} \\
(0.002)\end{array}$ & $\begin{array}{c}0.007^{\star * *} \\
(0.002)\end{array}$ & $\begin{array}{l}0.008^{\star \star \star} \\
(0.002)\end{array}$ & $\begin{array}{c}0.009^{\star * *} \\
(0.002)\end{array}$ & $\begin{array}{l}0.008^{\star * \star} \\
(0.002)\end{array}$ & $\begin{array}{l}0.008^{\star * \star} \\
(0.002)\end{array}$ \\
\hline Institutional quality & $\begin{array}{l}0.025^{\star \star} \\
(0.011)\end{array}$ & $\begin{array}{l}0.026^{* *} \\
(0.011)\end{array}$ & $\begin{array}{l}0.025^{\star \star} \\
(0.011)\end{array}$ & $\begin{array}{l}0.027^{\star *} \\
(0.011)\end{array}$ & $\begin{array}{l}0.025^{\star *} \\
(0.011)\end{array}$ & $\begin{array}{l}0.027^{\star *} \\
(0.011)\end{array}$ & $\begin{array}{c}0.012 \\
(0.012)\end{array}$ & $\begin{array}{c}0.014 \\
(0.012)\end{array}$ & $\begin{array}{c}0.013 \\
(0.012)\end{array}$ & $\begin{array}{c}0.015 \\
(0.012)\end{array}$ & $\begin{array}{c}0.013 \\
(0.012)\end{array}$ & $\begin{array}{c}0.016 \\
(0.012)\end{array}$ \\
\hline Capital account openness & $\begin{array}{c}0.002 \\
(0.002)\end{array}$ & $\begin{array}{c}0.002 \\
(0.002)\end{array}$ & $\begin{array}{c}0.002 \\
(0.002)\end{array}$ & $\begin{array}{c}0.000 \\
(0.002)\end{array}$ & $\begin{array}{c}0.002 \\
(0.002)\end{array}$ & $\begin{array}{c}0.000 \\
(0.002)\end{array}$ & $\begin{array}{l}0.010^{\star * \star} \\
(0.002)\end{array}$ & $\begin{array}{l}0.009^{\star \star \star} \\
(0.002)\end{array}$ & $\begin{array}{l}0.009^{\star \star *} \\
(0.002)\end{array}$ & $\begin{array}{l}0.008^{\star \star \star} \\
(0.002)\end{array}$ & $\begin{array}{l}0.011^{\star \star \star} \\
(0.002)\end{array}$ & $\begin{array}{c}0.009^{\star * *} \\
(0.002)\end{array}$ \\
\hline Log-total other borrowing & $\begin{array}{c}0.069 \\
(0.048) \\
\end{array}$ & $\begin{array}{c}0.078 \\
(0.049) \\
\end{array}$ & $\begin{array}{c}0.077 \\
(0.049) \\
\end{array}$ & $\begin{array}{c}0.079 \\
(0.049) \\
\end{array}$ & $\begin{array}{c}0.076 \\
(0.049) \\
\end{array}$ & $\begin{array}{c}0.073 \\
(0.048) \\
\end{array}$ & $\begin{array}{c}0.135 \\
(0.090) \\
\end{array}$ & $\begin{array}{c}0.130 \\
(0.091) \\
\end{array}$ & $\begin{array}{c}0.127 \\
(0.095) \\
\end{array}$ & $\begin{array}{c}0.129 \\
(0.091) \\
\end{array}$ & $\begin{array}{c}0.125 \\
(0.092) \\
\end{array}$ & $\begin{array}{c}0.133 \\
(0.095) \\
\end{array}$ \\
\hline \multicolumn{13}{|l|}{$\underline{\text { GFC } \text { and interactions }}$} \\
\hline$\overline{\text { Log-real trade }{ }^{\star} \mathrm{GFC}}$ & $\begin{array}{c}0.022 \\
(0.028)\end{array}$ & & & & & $\begin{array}{c}0.041 \\
(0.027)\end{array}$ & $\begin{array}{l}-0.012 \\
(0.029)\end{array}$ & & & & & $\begin{array}{l}-0.009 \\
(0.028)\end{array}$ \\
\hline Geographical distance*GFC & & $\begin{array}{l}-0.077 \\
(0.062)\end{array}$ & & & & $\begin{array}{l}-0.039 \\
(0.068)\end{array}$ & & $\begin{array}{c}-0.285^{\star * *} \\
(0.060)\end{array}$ & & & & $\begin{array}{c}-0.285^{\star * \star} \\
(0.062)\end{array}$ \\
\hline Bank capital-to-assets ratio*GFC & & & $\begin{array}{l}-0.016 \\
(0.024)\end{array}$ & & & $\begin{array}{l}-0.024 \\
(0.024)\end{array}$ & & & $\begin{array}{c}0.004 \\
(0.026)\end{array}$ & & & $\begin{array}{l}-0.005 \\
(0.025)\end{array}$ \\
\hline Capital account openness ${ }^{*}$ GFC & & & & $\begin{array}{l}0.006^{* *} \\
(0.002)\end{array}$ & & $\begin{array}{l}0.006^{\star *} \\
(0.002)\end{array}$ & & & & $\begin{array}{c}0.007^{\star \star \star} \\
(0.002)\end{array}$ & & $\begin{array}{c}0.003 \\
(0.002)\end{array}$ \\
\hline Institutional quality ${ }^{*} \mathrm{GFC}$ & & & & & $\begin{array}{c}0.016 \\
(0.012)\end{array}$ & $\begin{array}{c}0.011 \\
(0.012)\end{array}$ & & & & & $\begin{array}{c}0.030^{\star \star \star} \\
(0.011)\end{array}$ & $\begin{array}{c}0.028^{\star * *} \\
(0.011)\end{array}$ \\
\hline Observations & 4,200 & 4,200 & 4,200 & 4,200 & 4,200 & 4,200 & 4,200 & 4,200 & 4,200 & 4,200 & 4,200 & 4,200 \\
\hline R-squared & 0.748 & 0.749 & 0.748 & 0.749 & 0.749 & 0.750 & 0.717 & 0.720 & 0.717 & 0.719 & 0.718 & 0.721 \\
\hline
\end{tabular}

Notes: The dependent variable is log-SLE (columns 1-6) and log-non-SLE (columns 7-12). Sample period: 1995-2012. All regressions include year and country fixed effects. Standard errors are clustered on country pair. See Table 2 for variable definitions and sources. 
Table B5. Robustness to adding lagged dependent variable

\begin{tabular}{|c|c|c|c|c|c|c|}
\hline & $(1)$ & $(2)$ & (3) & $(4)$ & $(5)$ & $(6)$ \\
\hline & \multicolumn{3}{|c|}{ Dependent variable: Log-SLE } & \multicolumn{3}{|c|}{ Dependent variable: Log-non-SLE } \\
\hline & Full & Full & Full & Full & Full & Full \\
\hline & OLS & OLS & $\begin{array}{c}\text { Bias- } \\
\text { correction }\end{array}$ & OLS & OLS & $\begin{array}{c}\text { Bias- } \\
\text { correction }\end{array}$ \\
\hline \multicolumn{7}{|l|}{ Within-pair } \\
\hline Lagged dependent variable & $\begin{array}{c}0.780^{* * *} \\
(0.012)\end{array}$ & $\begin{array}{c}0.474^{* * *} \\
(0.019)\end{array}$ & $\begin{array}{c}0.545^{\star \star *} \\
(0.007)\end{array}$ & $\begin{array}{c}0.808^{\star * *} \\
(0.011)\end{array}$ & $\begin{array}{c}0.493^{\star * *} \\
(0.020)\end{array}$ & $\begin{array}{c}0.584^{\star \star \star} \\
(0.016)\end{array}$ \\
\hline Log-real trade & $\begin{array}{l}0.085^{\star \star \star} \\
(0.009)\end{array}$ & $\begin{array}{c}0.056^{\star \star *} \\
(0.015)\end{array}$ & $\begin{array}{c}0.054 \\
(0.057)\end{array}$ & $\begin{array}{c}0.075^{\star \star *} \\
(0.011)\end{array}$ & $\begin{array}{c}0.027^{* * *} \\
(0.009)\end{array}$ & $\begin{array}{c}0.027 \\
(0.066)\end{array}$ \\
\hline 1: Common language & $\begin{array}{c}0.077^{\star \star *} \\
(0.027)\end{array}$ & & & $\begin{array}{c}0.031 \\
(0.029)\end{array}$ & & \\
\hline Log-geographical distance & $\begin{array}{c}-0.086^{\star * *} \\
(0.017)\end{array}$ & & & $\begin{array}{c}-0.135^{\star * *} \\
(0.020)\end{array}$ & & \\
\hline 1: Foreign affiliate & $\begin{array}{c}0.141^{* * *} \\
(0.021)\end{array}$ & $\begin{array}{c}0.027 \\
(0.036)\end{array}$ & $\begin{array}{c}0.017 \\
(0.014)\end{array}$ & $\begin{array}{c}0.156^{\star \star *} \\
(0.024)\end{array}$ & $\begin{array}{l}0.073^{*} \\
(0.039)\end{array}$ & $\begin{array}{c}0.070^{\star \star \star} \\
(0.015)\end{array}$ \\
\hline \multicolumn{7}{|l|}{ Lender characteristics } \\
\hline Log-per capita GDP & $\begin{array}{l}-0.013 \\
(0.144)\end{array}$ & $\begin{array}{l}-0.087 \\
(0.215)\end{array}$ & $\begin{array}{l}-0.008 \\
(0.082)\end{array}$ & $\begin{array}{c}0.035 \\
(0.147)\end{array}$ & $\begin{array}{c}0.236 \\
(0.200)\end{array}$ & $\begin{array}{c}0.151^{* * *} \\
(0.042)\end{array}$ \\
\hline Bank assets (\% GDP) & $\begin{array}{c}-0.001^{* * *} \\
(0.000)\end{array}$ & $\begin{array}{l}-0.000 \\
(0.000)\end{array}$ & $\begin{array}{l}-0.000 \\
(0.000)\end{array}$ & $\begin{array}{l}-0.000 \\
(0.000)\end{array}$ & $\begin{array}{c}0.000 \\
(0.000)\end{array}$ & $\begin{array}{c}0.000 \\
(0.001)\end{array}$ \\
\hline Bank capital-to-assets ratio & $\begin{array}{l}-0.016^{\star *} \\
(0.007)\end{array}$ & $\begin{array}{c}-0.033^{* * *} \\
(0.009)\end{array}$ & $\begin{array}{c}-0.031^{* *} \\
(0.014)\end{array}$ & $\begin{array}{c}0.012 \\
(0.009)\end{array}$ & $\begin{array}{l}-0.006 \\
(0.011)\end{array}$ & $\begin{array}{l}-0.007 \\
(0.019)\end{array}$ \\
\hline Log-total other lending & $\begin{array}{l}0.302^{* \star *} \\
(0.021)\end{array}$ & $\begin{array}{c}0.513^{\star * *} \\
(0.028)\end{array}$ & $\begin{array}{c}0.476^{\star \star *} \\
(0.016) \\
\end{array}$ & $\begin{array}{c}0.021 \\
(0.016) \\
\end{array}$ & $\begin{array}{c}0.170^{* * *} \\
(0.044) \\
\end{array}$ & $\begin{array}{c}0.147^{* * *} \\
(0.021) \\
\end{array}$ \\
\hline \multicolumn{7}{|l|}{ Borrower characteristics } \\
\hline Log-per capita GDP & $\begin{array}{c}0.035 \\
(0.084)\end{array}$ & $\begin{array}{c}0.060 \\
(0.118)\end{array}$ & $\begin{array}{c}0.046^{\star \star \star} \\
(0.012)\end{array}$ & $\begin{array}{c}0.401^{\star \star \star} \\
(0.076)\end{array}$ & $\begin{array}{c}0.446^{\star \star \star} \\
(0.124)\end{array}$ & $\begin{array}{c}0.394^{\star \star *} \\
(0.056)\end{array}$ \\
\hline Bank assets (\% GDP) & $\begin{array}{c}0.000 \\
(0.000)\end{array}$ & $\begin{array}{c}0.000 \\
(0.000)\end{array}$ & $\begin{array}{c}0.000 \\
(0.000)\end{array}$ & $\begin{array}{c}0.001^{* * *} \\
(0.000)\end{array}$ & $\begin{array}{l}0.002^{* \star *} \\
(0.000)\end{array}$ & $\begin{array}{c}0.002^{* * *} \\
(0.000)\end{array}$ \\
\hline Institutional quality & $\begin{array}{l}0.011^{\star *} \\
(0.005)\end{array}$ & $\begin{array}{c}0.003 \\
(0.006)\end{array}$ & $\begin{array}{c}0.004 \\
(0.014)\end{array}$ & $\begin{array}{l}-0.000 \\
(0.005)\end{array}$ & $\begin{array}{l}-0.006 \\
(0.007)\end{array}$ & $\begin{array}{l}-0.005 \\
(0.017)\end{array}$ \\
\hline Capital account openness & $\begin{array}{c}0.000 \\
(0.001)\end{array}$ & $\begin{array}{c}0.000 \\
(0.001)\end{array}$ & $\begin{array}{c}0.000 \\
(0.001)\end{array}$ & $\begin{array}{c}0.002 \\
(0.001)\end{array}$ & $\begin{array}{c}0.004^{\star \star *} \\
(0.001)\end{array}$ & $\begin{array}{l}0.004^{* * *} \\
(0.000)\end{array}$ \\
\hline Log-total other borrowing & $\begin{array}{l}0.052^{\star \star \star} \\
(0.019)\end{array}$ & $\begin{array}{l}0.117^{\star \star \star} \\
(0.026)\end{array}$ & $\begin{array}{c}0.127^{\star \star \star} \\
(0.020)\end{array}$ & $\begin{array}{c}0.024 \\
(0.029) \\
\end{array}$ & $\begin{array}{l}0.179^{\star \star \star *} \\
(0.035)\end{array}$ & $\begin{array}{c}0.152^{\star \star \star} \\
(0.053)\end{array}$ \\
\hline Year FE & yes & yes & yes & yes & yes & yes \\
\hline Country FE & yes & no & no & yes & no & no \\
\hline Country-pair FE & no & yes & no & no & yes & no \\
\hline Observations & 7,895 & 7,895 & 8,072 & 7,895 & 7,895 & 8,072 \\
\hline R-squared & 0.942 & 0.960 & - & 0.926 & 0.945 & - \\
\hline
\end{tabular}

Notes: The dependent variable is log-SLE (columns 1-3) and log-non-SLE (columns 4-6). Sample period: 19952012. All regressions include year fixed effects. Specifications in columns 1 and 4 are estimated using OLS with country fixed effects. Specifications in columns 2 and 5 are estimated using OLS with country-pair fixed effects. Specifications in columns 3 and 6 are estimated using the bias-corrected least squares dummy variable (LSDV) dynamic panel data estimator with initial Anderson-Hsiao values for the coefficients and bootstrapped standard errors (Bruno, 2005). In all columns other than 3 and 5, standard errors are clustered on country pair. See Table 2 for variable definitions and sources. 
Table B6. Robustness to alternative sample period: 1995-2007 (pre-global financial crisis)

\begin{tabular}{|c|c|c|c|c|c|c|}
\hline \multirow[b]{4}{*}{ Within-pair } & $(1)$ & $(2)$ & (3) & $(4)$ & $(5)$ & (6) \\
\hline & \multicolumn{3}{|c|}{ Dependent variable: Log-SLE } & \multicolumn{3}{|c|}{ Dependent variable: Log-non-SLE } \\
\hline & Full & $\begin{array}{c}\mathrm{AE} \\
\text { borrowers }\end{array}$ & $\begin{array}{c}\text { EME } \\
\text { borrowers }\end{array}$ & Full & $\begin{array}{c}\mathrm{AE} \\
\text { borrowers }\end{array}$ & $\begin{array}{c}\text { EME } \\
\text { borrowers }\end{array}$ \\
\hline & & & & & & \\
\hline$\overline{\text { Log-real trade }}$ & $\begin{array}{c}0.213^{* * *} \\
(0.029)\end{array}$ & $\begin{array}{c}0.164^{* * *} \\
(0.031)\end{array}$ & $\begin{array}{c}0.205^{\star * *} \\
(0.078)\end{array}$ & $\begin{array}{c}0.210^{* * *} \\
(0.034)\end{array}$ & $\begin{array}{c}0.120^{* * *} \\
(0.033)\end{array}$ & $\begin{array}{c}0.344^{* * *} \\
(0.071)\end{array}$ \\
\hline 1: Common language & $\begin{array}{c}0.303^{* * *} \\
(0.109)\end{array}$ & $\begin{array}{c}0.171 \\
(0.124)\end{array}$ & $\begin{array}{l}0.507^{\star \star} \\
(0.205)\end{array}$ & $\begin{array}{c}0.198^{*} \\
(0.115)\end{array}$ & $\begin{array}{c}0.101 \\
(0.160)\end{array}$ & $\begin{array}{c}0.663^{* * *} \\
(0.163)\end{array}$ \\
\hline Log-geographical distance & $\begin{array}{c}-0.400^{* * *} \\
(0.059)\end{array}$ & $\begin{array}{c}-0.580^{* * *} \\
(0.077)\end{array}$ & $\begin{array}{c}-0.532^{\star * *} \\
(0.153)\end{array}$ & $\begin{array}{c}-0.793^{\star * *} \\
(0.064)\end{array}$ & $\begin{array}{c}-0.899^{* * *} \\
(0.087)\end{array}$ & $\begin{array}{c}-0.899^{* * *} \\
(0.125)\end{array}$ \\
\hline 1: Foreign affiliate & $\begin{array}{c}0.472^{* * *} \\
(0.067)\end{array}$ & $\begin{array}{c}0.393^{* * *} \\
(0.084)\end{array}$ & $\begin{array}{c}0.359^{* * *} \\
(0.112)\end{array}$ & $\begin{array}{c}0.691^{* * *} \\
(0.073)\end{array}$ & $\begin{array}{c}0.644^{* * *} \\
(0.106)\end{array}$ & $\begin{array}{c}0.532^{* * *} \\
(0.098)\end{array}$ \\
\hline \multicolumn{7}{|l|}{ Lender characteristics } \\
\hline Log-per capita GDP & $\begin{array}{l}-0.011 \\
(0.435)\end{array}$ & $\begin{array}{l}-0.227 \\
(0.560)\end{array}$ & $\begin{array}{c}0.372 \\
(0.639)\end{array}$ & $\begin{array}{l}-0.045 \\
(0.446)\end{array}$ & $\begin{array}{c}0.817 \\
(0.532)\end{array}$ & $\begin{array}{l}-0.846 \\
(0.748)\end{array}$ \\
\hline Bank assets (\% GDP) & $\begin{array}{c}-0.002^{\star *} \\
(0.001)\end{array}$ & $\begin{array}{c}-0.002 \\
(0.001)\end{array}$ & $\begin{array}{l}-0.002 \\
(0.002)\end{array}$ & $\begin{array}{c}0.002 \\
(0.001)\end{array}$ & $\begin{array}{c}0.000 \\
(0.002)\end{array}$ & $\begin{array}{l}0.005^{\star *} \\
(0.002)\end{array}$ \\
\hline Bank capital-to-assets ratio & $\begin{array}{c}-0.061^{* * *} \\
(0.017)\end{array}$ & $\begin{array}{c}-0.089^{* * *} \\
(0.024)\end{array}$ & $\begin{array}{c}-0.045^{\star *} \\
(0.022)\end{array}$ & $\begin{array}{c}0.005 \\
(0.021)\end{array}$ & $\begin{array}{c}0.037 \\
(0.027)\end{array}$ & $\begin{array}{l}-0.045 \\
(0.031)\end{array}$ \\
\hline Log-total other lending & $\begin{array}{c}0.570^{* \star *} \\
(0.036)\end{array}$ & $\begin{array}{c}0.607^{* * *} \\
(0.058)\end{array}$ & $\begin{array}{c}0.512^{* * *} \\
(0.047)\end{array}$ & $\begin{array}{l}-0.017 \\
(0.048)\end{array}$ & $\begin{array}{c}-0.229^{* * *} \\
(0.064)\end{array}$ & $\begin{array}{c}0.153^{* * *} \\
(0.056)\end{array}$ \\
\hline \multicolumn{7}{|l|}{ Borrower characteristics } \\
\hline$\overline{\text { Log-per capita GDP }}$ & $\begin{array}{l}-0.087 \\
(0.192)\end{array}$ & $\begin{array}{c}-1.799^{* * *} \\
(0.483)\end{array}$ & $\begin{array}{l}-0.079 \\
(0.287)\end{array}$ & $\begin{array}{c}0.743^{* * *} \\
(0.193)\end{array}$ & $\begin{array}{c}2.429^{* * *} \\
(0.642)\end{array}$ & $\begin{array}{c}-0.057 \\
(0.307)\end{array}$ \\
\hline Bank assets (\% GDP) & $\begin{array}{c}0.002 \\
(0.001)\end{array}$ & $\begin{array}{c}-0.000 \\
(0.001)\end{array}$ & $\begin{array}{c}0.007^{* * *} \\
(0.003)\end{array}$ & $\begin{array}{c}0.009^{* * *} \\
(0.001)\end{array}$ & $\begin{array}{c}0.005^{\star * *} \\
(0.002)\end{array}$ & $\begin{array}{c}0.014^{* * *} \\
(0.003)\end{array}$ \\
\hline Institutional quality & $\begin{array}{l}-0.001 \\
(0.012)\end{array}$ & $\begin{array}{l}-0.067 \\
(0.073)\end{array}$ & $\begin{array}{c}0.017^{*} \\
(0.010)\end{array}$ & $\begin{array}{c}0.002 \\
(0.012)\end{array}$ & $\begin{array}{l}-0.042 \\
(0.080)\end{array}$ & $\begin{array}{c}0.012 \\
(0.013)\end{array}$ \\
\hline Capital account openness & $\begin{array}{c}0.003 \\
(0.002)\end{array}$ & $\begin{array}{c}0.004 \\
(0.005)\end{array}$ & $\begin{array}{c}0.002 \\
(0.002)\end{array}$ & $\begin{array}{c}0.009^{* * *} \\
(0.002)\end{array}$ & $\begin{array}{l}-0.004 \\
(0.006)\end{array}$ & $\begin{array}{c}0.009^{* * *} \\
(0.003)\end{array}$ \\
\hline Log-total other borrowing & $\begin{array}{l}0.103^{\star *} \\
(0.042)\end{array}$ & $\begin{array}{c}0.173^{\star * *} \\
(0.060)\end{array}$ & $\begin{array}{l}0.103^{*} \\
(0.055)\end{array}$ & $\begin{array}{c}0.045 \\
(0.084)\end{array}$ & $\begin{array}{l}-0.021 \\
(0.122)\end{array}$ & $\begin{array}{c}0.095 \\
(0.122)\end{array}$ \\
\hline Observations & 6,772 & 3,320 & 3,040 & 6,772 & 3,320 & 3,040 \\
\hline R-squared & 0.812 & 0.861 & 0.760 & 0.793 & 0.766 & 0.732 \\
\hline
\end{tabular}

Notes: The dependent variable is log-SLE (columns 1-3) and log-non-SLE (columns 4-6). In these specifications we exclude the global financial crisis years (2008-2012). All regressions include year and country fixed effects. Standard errors are clustered on country pair. See Table 2 for variable definitions and sources. 
Table B7. Additional results: Allowing for threshold effects of lender regulatory capital

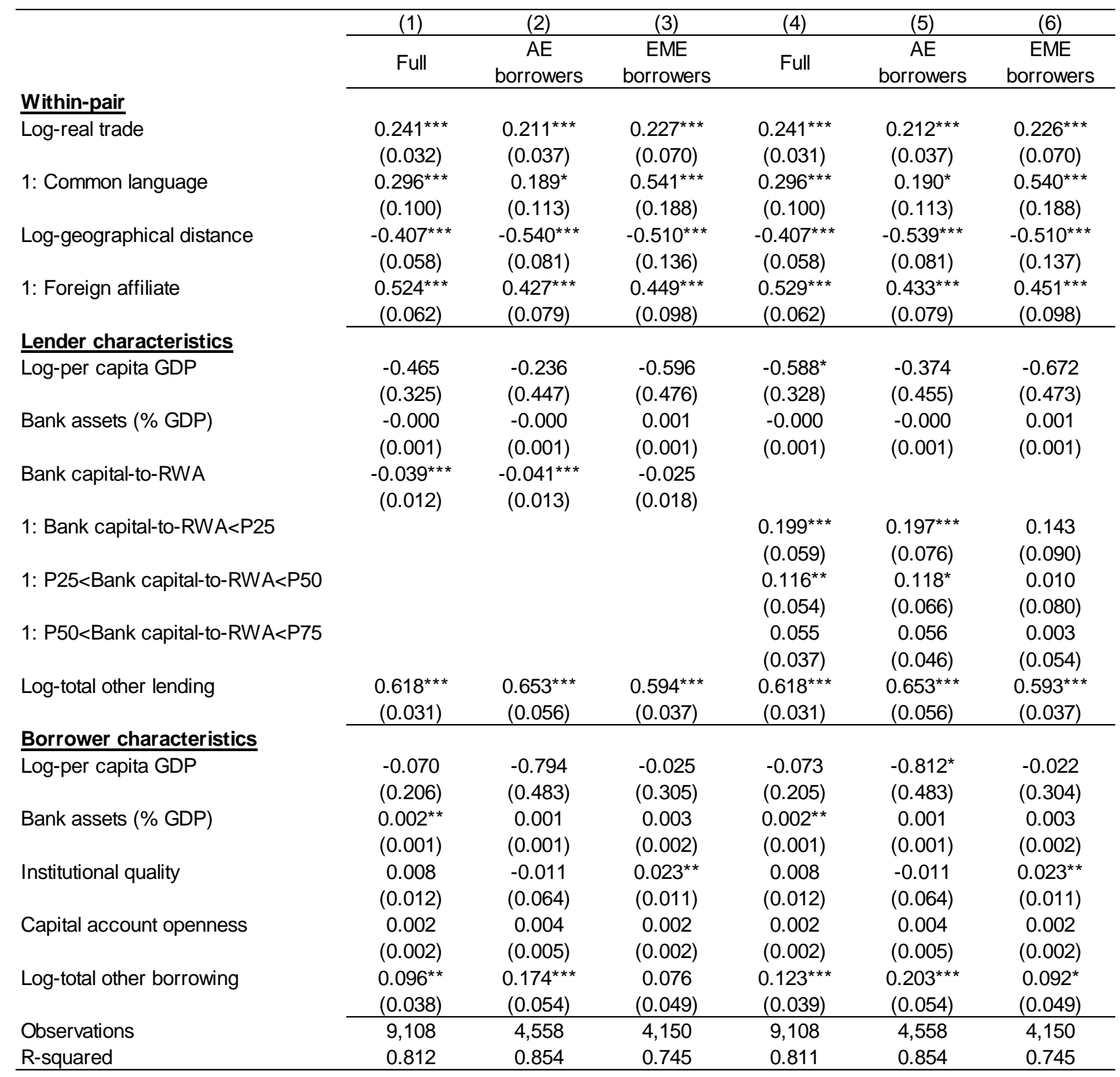

Notes: The dependent variable is log-SLE. Sample period: 1995-2012. In these specifications we explore threshold effects in the effect of lender country bank (regulatory) capital ratios and cross-border loan exposures. In columns 1-3 we use bank total regulatory capital to risk weighted assets (RWA) ratio instead of bank capitalto-total assets ratio (as in the baseline). In columns 4-6 we replace the continuous capital ratio with indicators for banks with regulatory capital ratios below the $25^{\text {th }}$ percentile, between the $25^{\text {th }}$ and $50^{\text {th }}$ percentile, and between the $50^{\text {th }}$ and $75^{\text {th }}$ percentile. The omitted category contains lender countries with banks whose capital ratios are above the $75^{\text {th }}$ percentile. All regressions include year and country fixed effects. Standard errors are clustered on country pair. See Table 2 for variable definitions and sources. 
Table B8. Additional results: Probability of no within-pair syndication activity

\begin{tabular}{|c|c|c|c|c|c|c|}
\hline & $(1)$ & $(2)$ & (3) & $(4)$ & $(5)$ & (6) \\
\hline & & probability & del & & Probit & \\
\hline & Full & $\begin{array}{c}\mathrm{AE} \\
\text { borrowers }\end{array}$ & $\begin{array}{c}\text { EME } \\
\text { borrowers }\end{array}$ & Full & $\begin{array}{c}\mathrm{AE} \\
\text { borrowers } \\
\end{array}$ & $\begin{array}{c}\text { EME } \\
\text { borrowers }\end{array}$ \\
\hline \multicolumn{7}{|l|}{ Within-pair } \\
\hline Log-real trade & $\begin{array}{c}-0.011^{* *} \\
(0.005)\end{array}$ & $\begin{array}{l}-0.006 \\
(0.004)\end{array}$ & $\begin{array}{l}-0.017^{*} \\
(0.009)\end{array}$ & $\begin{array}{c}-0.162^{* *} \\
(0.077)\end{array}$ & $\begin{array}{l}-0.024 \\
(0.116)\end{array}$ & $\begin{array}{c}-0.367^{\star *} \\
(0.150)\end{array}$ \\
\hline 1: Common language & $\begin{array}{c}-0.035^{\star *} \\
(0.016)\end{array}$ & $\begin{array}{l}-0.003 \\
(0.008)\end{array}$ & $\begin{array}{l}-0.041^{*} \\
(0.022)\end{array}$ & $\begin{array}{l}-4.313 \\
(7.401)\end{array}$ & $\begin{array}{c}-1.336^{\star \star *} \\
(4.475)\end{array}$ & $\begin{array}{c}-6.424^{\star \star *} \\
(1.421)\end{array}$ \\
\hline Log-geographical distance & $\begin{array}{l}-0.005 \\
(0.008)\end{array}$ & $\begin{array}{l}-0.006 \\
(0.007)\end{array}$ & $\begin{array}{c}0.064^{\star * *} \\
(0.024)\end{array}$ & $\begin{array}{l}1.069^{* *} \\
(0.493)\end{array}$ & $\begin{array}{l}1.377^{\star \star \star} \\
(0.385)\end{array}$ & $\begin{array}{c}0.543 \\
(0.592)\end{array}$ \\
\hline 1: Foreign affiliate & $\begin{array}{l}-0.016 \\
(0.011) \\
\end{array}$ & $\begin{array}{l}-0.020 \\
(0.014) \\
\end{array}$ & $\begin{array}{c}0.003 \\
(0.014) \\
\end{array}$ & $\begin{array}{c}0.013 \\
(0.350) \\
\end{array}$ & $\begin{array}{l}-0.415 \\
(0.512) \\
\end{array}$ & $\begin{array}{c}0.290 \\
(0.422) \\
\end{array}$ \\
\hline \multicolumn{7}{|l|}{ Lender characteristics } \\
\hline Log-per capita GDP & $\begin{array}{c}-0.317^{\star * \star} \\
(0.052)\end{array}$ & $\begin{array}{c}-0.334^{\star * \star} \\
(0.061)\end{array}$ & $\begin{array}{c}-0.361^{* * *} \\
(0.070)\end{array}$ & $\begin{array}{c}-0.702^{\star *} \\
(0.299)\end{array}$ & $\begin{array}{l}-0.112 \\
(0.430)\end{array}$ & $\begin{array}{l}-2.005^{\star} \\
(1.048)\end{array}$ \\
\hline Bank assets (\% GDP) & $\begin{array}{c}0.000 \\
(0.000)\end{array}$ & $\begin{array}{c}0.000 \\
(0.000)\end{array}$ & $\begin{array}{c}-0.000 \\
(0.000)\end{array}$ & $\begin{array}{c}0.002 \\
(0.003)\end{array}$ & $\begin{array}{c}0.002 \\
(0.005)\end{array}$ & $\begin{array}{c}0.003 \\
(0.003)\end{array}$ \\
\hline Bank capital-to-assets ratio & $\begin{array}{l}0.012^{* \star *} \\
(0.004)\end{array}$ & $\begin{array}{l}0.018^{\star \star \star *} \\
(0.005)\end{array}$ & $\begin{array}{c}0.015^{\star * *} \\
(0.005)\end{array}$ & $\begin{array}{c}0.674^{\star * *} \\
(0.148)\end{array}$ & $\begin{array}{c}0.688^{\star * *} \\
(0.176)\end{array}$ & $\begin{array}{c}0.600^{\star * \star} \\
(0.115)\end{array}$ \\
\hline Log-total other lending & $\begin{array}{c}0.004 \\
(0.003) \\
\end{array}$ & $\begin{array}{c}0.005 \\
(0.004) \\
\end{array}$ & $\begin{array}{c}0.001 \\
(0.005) \\
\end{array}$ & $\begin{array}{c}-0.215^{\star \star *} \\
(0.073) \\
\end{array}$ & $\begin{array}{l}-0.145 \\
(0.125) \\
\end{array}$ & $\begin{array}{l}-0.136 \\
(0.092) \\
\end{array}$ \\
\hline \multicolumn{7}{|l|}{ Borrower characteristics } \\
\hline Log-per capita GDP & $\begin{array}{c}0.003 \\
(0.026)\end{array}$ & $\begin{array}{c}0.014 \\
(0.060)\end{array}$ & $\begin{array}{c}0.011 \\
(0.026)\end{array}$ & $\begin{array}{l}-0.001 \\
(0.488)\end{array}$ & $\begin{array}{l}-1.266 \\
(1.241)\end{array}$ & $\begin{array}{c}0.126 \\
(0.742)\end{array}$ \\
\hline Bank assets (\% GDP) & $\begin{array}{c}-0.000^{\star * *} \\
(0.000)\end{array}$ & $\begin{array}{l}-0.000 \\
(0.000)\end{array}$ & $\begin{array}{l}-0.000 \\
(0.000)\end{array}$ & $\begin{array}{c}-0.011^{\star * *} \\
(0.004)\end{array}$ & $\begin{array}{l}-0.010^{*} \\
(0.005)\end{array}$ & $\begin{array}{l}-0.001 \\
(0.006)\end{array}$ \\
\hline Institutional quality & $\begin{array}{c}-0.000 \\
(0.001)\end{array}$ & $\begin{array}{l}-0.018^{*} \\
(0.011)\end{array}$ & $\begin{array}{l}-0.000 \\
(0.001)\end{array}$ & $\begin{array}{c}-0.008 \\
(0.038)\end{array}$ & $\begin{array}{l}-0.087 \\
(0.092)\end{array}$ & $\begin{array}{c}0.007 \\
(0.047)\end{array}$ \\
\hline Capital account openness & $\begin{array}{c}0.000 \\
(0.000)\end{array}$ & $\begin{array}{c}0.000 \\
(0.001)\end{array}$ & $\begin{array}{c}0.000 \\
(0.000)\end{array}$ & $\begin{array}{l}-0.007 \\
(0.007)\end{array}$ & $\begin{array}{c}0.020 \\
(0.025)\end{array}$ & $\begin{array}{l}-0.011 \\
(0.009)\end{array}$ \\
\hline Log-total other borrowing & $\begin{array}{l}-0.001 \\
(0.006) \\
\end{array}$ & $\begin{array}{l}-0.000 \\
(0.006) \\
\end{array}$ & $\begin{array}{l}-0.002 \\
(0.010) \\
\end{array}$ & $\begin{array}{l}-0.341 \\
(0.334) \\
\end{array}$ & $\begin{array}{l}-0.404^{* *} \\
(0.202) \\
\end{array}$ & $\begin{array}{c}-0.284 \\
(0.251) \\
\end{array}$ \\
\hline Observations & 9,639 & 4,704 & 4,466 & 9,639 & 4,704 & 4,466 \\
\hline R-squared & 0.270 & 0.196 & 0.461 & - & - & - \\
\hline
\end{tabular}

Notes: The dependent variable is the probability that we observe no syndication activity (SLE=0) within a country pair. Sample period: 1995-2012. In columns 1-3 we estimate a linear probability model with year and country fixed effects. In columns 4-6 we estimate a probit with year dummies but random country effects. Standard errors are clustered on country pair. See Table 2 for variable definitions and sources. 